\title{
N2 Fixation by non-heterocystous cyanobacteria
}

Bergman, B.; Gallon, J.R.; Rai, A.N.; Stal, L.J.

\section{Publication date}

1997

Published in

FEMS Microbiology Reviews

Link to publication

Citation for published version (APA):

Bergman, B., Gallon, J. R., Rai, A. N., \& Stal, L. J. (1997). N2 Fixation by non-heterocystous cyanobacteria. FEMS Microbiology Reviews, (19), 139-185.

\section{General rights}

It is not permitted to download or to forward/distribute the text or part of it without the consent of the author(s) and/or copyright holder(s), other than for strictly personal, individual use, unless the work is under an open content license (like Creative Commons).

\section{Disclaimer/Complaints regulations}

If you believe that digital publication of certain material infringes any of your rights or (privacy) interests, please let the Library know, stating your reasons. In case of a legitimate complaint, the Library will make the material inaccessible and/or remove it from the website. Please Ask the Library: https://uba.uva.nl/en/contact, or a lette to: Library of the University of Amsterdam, Secretariat, Singel 425, 1012 WP Amsterdam, The Netherlands. Yo will be contacted as soon as possible. 


\title{
$\mathrm{N}_{2}$ Fixation by non-heterocystous cyanobacteria
}

\author{
B. Bergman ${ }^{a}$, J.R. Gallon ${ }^{\mathrm{b}}$, A.N. Rai ${ }^{\mathrm{c}}$, L.J. Stal ${ }^{\mathrm{d}, *}$ \\ a Department of Botany, University of Stockholm, S-106 91 Stockholm, Sweden \\ b Algal Research Unit and Biochemistry Research Group, School of Biological Sciences, University of Wales-Swansea, \\ Singleton Park, Swansea, SA2 8PP, UK \\ c North Eastern Hill University, Shillong 793014, India \\ ${ }^{\mathrm{d}}$ Nederlands Instituut voor Oecologisch Onderzoek, Centrum voor Estuariene en Mariene Oecologie, Vierstraat 28, \\ NL-4401 EA Yerseke, The Netherlands
}

Received 12 April 1996; revised 9 September 1996; accepted 10 September 1996

\begin{abstract}
Many, though not all, non-heterocystous cyanobacteria can fix $\mathrm{N}_{2}$. However, very few strains can fix $\mathrm{N}_{2}$ aerobically. Nevertheless, these organisms may make a substantial contribution to the global nitrogen cycle. In this general review, $\mathrm{N}_{2}$ fixation by laboratory cultures and natural populations of non-heterocystous cyanobacteria is considered. The properties and subcellular location of nitrogenase in these organisms is described, as is the response of $\mathrm{N}_{2}$ fixation to environmental factors such as fixed nitrogen, $\mathrm{O}_{2}$ and the pattern of illumination. The integration of $\mathrm{N}_{2}$ fixation with other aspects of cell metabolism (in particular photosynthesis) is also discussed. Similarities and differences between different individual strains of nonheterocystous cyanobacteria are highlighted.
\end{abstract}

Keywords: Non-heterocystous cyanobacteria; $\mathrm{N}_{2}$ fixation; Nitrogenase; Immunolocalization; ATP and reductant; Diurnal rhythm; Natural environment

\section{Contents}

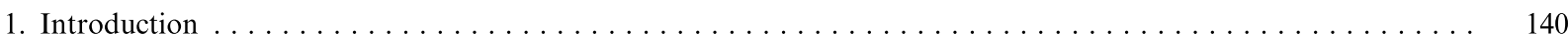

2. Non-heterocystous cyanobacteria capable of $\mathrm{N}_{2}$ fixation $\ldots \ldots \ldots \ldots$

3. $\mathrm{N}_{2}$ fixation by non-heterocystous cyanobacteria in the natural environment $\ldots \ldots \ldots 151$

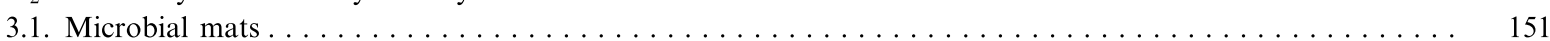

3.2. Terrestrial and freshwater cyanobacteria $\ldots \ldots \ldots \ldots \ldots \ldots$

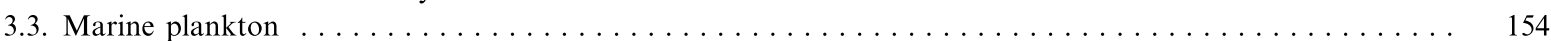

4. Nitrogen budgets and rates of non-heterocystous $\mathrm{N}_{2}$ fixation $\ldots \ldots \ldots \ldots$

\footnotetext{
* Corresponding author. Tel: +31 (113) 571920 ;

fax: +31 (113) 573 616: e-mail: stal@cemo.nioo.knaw.nl

Publication 2197 of the Centre of Estuarine and Coastal Research, Yerseke, The Netherlands.
}

0168-6445/97/ \$32.00 Copyright (C) 1997 Federation of European Microbiological Societies. Published by Elsevier Science B.V. PII S $0168-6445(96) 00028-9$ 


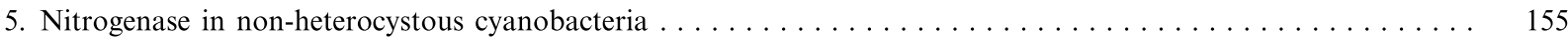

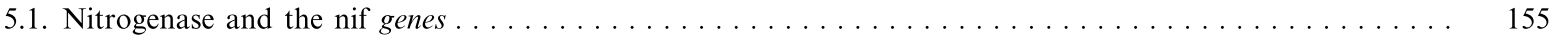

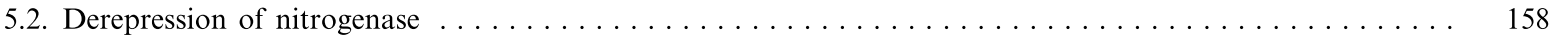

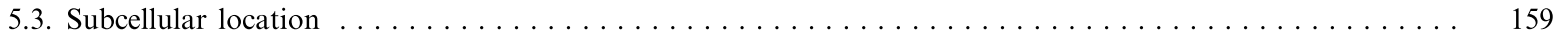

5.4. Intracellular concentrations of nitrogenase $\ldots \ldots \ldots 161$

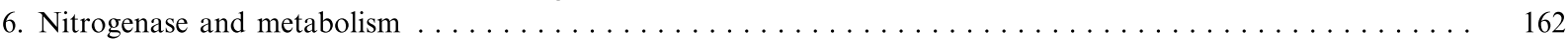

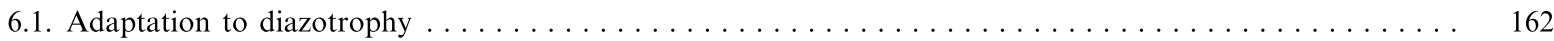

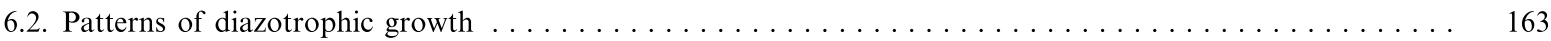

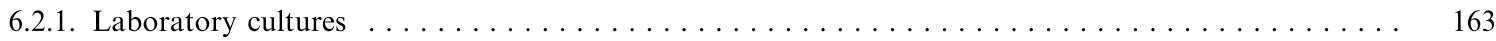

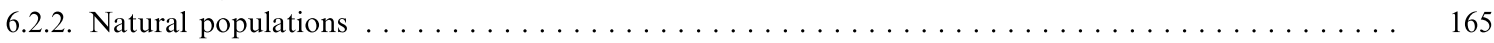

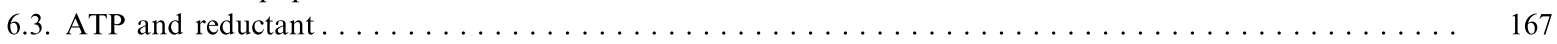

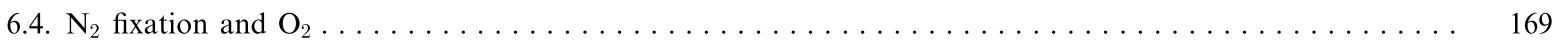

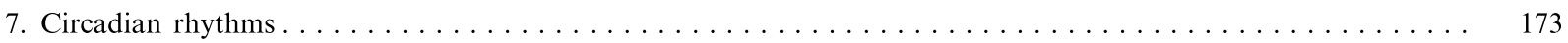

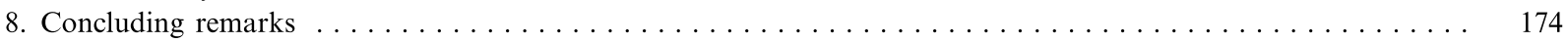

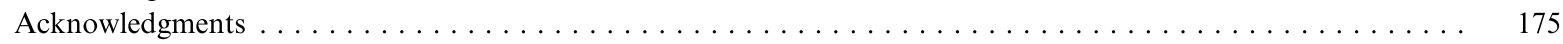

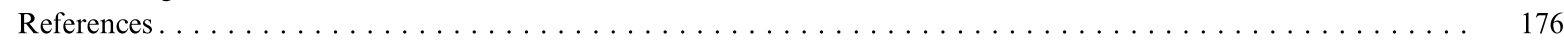

\section{Introduction}

Cyanobacteria are $\mathrm{O}_{2}$-evolving photosynthetic prokaryotes, many (though not all) of which can fix $\mathrm{N}_{2} \cdot \mathrm{N}_{2}$-fixing (diazotrophic) cyanobacteria can be broadly grouped as heterocystous and non-heterocystous forms. All heterocystous forms are capable of aerobic $\mathrm{N}_{2}$ fixation and, in the absence of combined nitrogen, $5-10 \%$ of their vegetative cells differentiate into specialized cells called heterocysts (heterocytes) that provide an environment suitable for the functioning of nitrogenase (the enzyme that catalyses $\mathrm{N}_{2}$ fixation). Unlike vegetative cells, heterocysts are photosynthetically inactive. They do not fix

\footnotetext{
${ }^{2}$ In this review, the terms 'oxic' and 'anoxic' refer to environments where $\mathrm{O}_{2}$ is, respectively, present or absent. The term 'aerobic' is used specifically to describe the presence of $\mathrm{O}_{2}$ at concentrations comparable to those in air. With cyanobacteria, however, strictly anoxic conditions are obtained in the light only when photosynthetic production of $\mathrm{O}_{2}$ is inhibited. Consistent with previous use of the term 'microaerobic', the expression 'micro-oxic' is therefore used to describe the environment of cultures grown in the absence of exogenous $\mathrm{O}_{2}$ but which remain capable of generating $\mathrm{O}_{2}$ photosynthetically. This term implies that $\mathrm{O}_{2}$ is present at concentrations lower than those in air. However, it must be emphasized that this cannot be stated with certainty since the concentration of $\mathrm{O}_{2}$ actually experienced by the organism has not usually been measured and may be much greater than realized. As an extreme example, cultures sparged with $\mathrm{O}_{2}$ free gas at low flow rates, yet exposed to intense illumination, may be exposed to a local concentration of $\mathrm{O}_{2}$ greater than that encountered by cultures illuminated less strongly and vigorously sparged with air.
}

$\mathrm{CO}_{2}$, nor do they produce $\mathrm{O}_{2}$. They also exhibit a high rate of respiratory $\mathrm{O}_{2}$ consumption and are surrounded by a thick, laminated cell wall that limits ingress of atmospheric gases, including $\mathrm{O}_{2}$. The internal environment of heterocysts is therefore virtually anoxic, which is ideal for nitrogenase, a notoriously $\mathrm{O}_{2}$-sensitive enzyme. In contrast, nonheterocystous cyanobacteria do not show cellular differentiation and until 1960 it was believed that such cyanobacteria were incapable of $\mathrm{N}_{2}$ fixation. Hints that this belief might be unfounded came from reports of aerobic $\mathrm{N}_{2}$ fixation by the non-heterocystous marine cyanobacterium Trichodesmium [1] and by laboratory cultures of the unicellular organism Gloeothece, then called Gloeocapsa [2]. Shortly afterwards, Stewart and Lex (1970) demonstrated $\mathrm{N}_{2}$ fixation under micro-oxic ${ }^{2}$ conditions by cultures of the filamentous cyanobacterium Plectonema boryanum [3], now considered to belong to the genus Leptolyngbya [4,5]. Since then, the list of nonheterocystous cyanobacteria that can fix $\mathrm{N}_{2}$ has been growing at a steady pace, with representatives isolated from marine, freshwater and terrestrial habitats. Currently 17 genera containing over 70 strains of non-heterocystous cyanobacteria are known to be capable of $\mathrm{N}_{2}$ fixation. Of these, most can fix $\mathrm{N}_{2}$ only when incubated under micro-oxic or anoxic conditions. However, a few strains can fix $\mathrm{N}_{2}$ aerobically. Because of their apparent ability to sustain both oxygenic photosynthesis and the $\mathrm{O}_{2}$-sensitive process of $\mathrm{N}_{2}$ fixation in the same cell, these partic- 
Table 1

Genera of non-heterocystous cyanobacteria with $\mathrm{N}_{2}$-fixing representatives ${ }^{\mathrm{a}}$

\begin{tabular}{|c|c|}
\hline Genera & References \\
\hline \multicolumn{2}{|l|}{ Unicellular forms } \\
\hline \multicolumn{2}{|l|}{ Section I } \\
\hline Gloeocapsa & {$[15-17]$} \\
\hline Gloeothece $^{\mathrm{b}}$ & {$[2,18,19]$; also see $[20]$ (Plate 1a) } \\
\hline Cyanothece $^{\mathrm{c}}$ & {$[18,19,21-31]$} \\
\hline Synechococcus ${ }^{\mathrm{d}}$ & {$[22]$} \\
\hline Synechocystis ${ }^{\mathrm{e}}$ & {$[32-34]$} \\
\hline \multicolumn{2}{|l|}{ Section II } \\
\hline Chroococcidiopsis & {$[18,22]$} \\
\hline Dermocarpa & {$[18,22]$} \\
\hline Myxosarcina & {$[18,22]$} \\
\hline Pleurocapsa group & {$[18,22]$} \\
\hline Xenococcus & {$[18,22]$} \\
\hline \multicolumn{2}{|l|}{ Filamentous forms } \\
\hline LPP Group ${ }^{f}$ (Lyngbya, Phormidium, Plectonema) & {$[3,18,22,35-37]$ (Plectonema boryanum is illustrated in Plate $1 \mathrm{~d}$ ) } \\
\hline Symploca $^{\mathrm{g}}$ & {$[38,39]$} \\
\hline Microcoleus & {$[40,41]$} \\
\hline Oscillatoria & {$[18,22,42-47]$ (Plate 1c) } \\
\hline Pseudanabaena ${ }^{\mathrm{h}}$ & {$[18,22,24]$} \\
\hline Trichodesmium & {$[1,48-52]$ (Plate 1b) } \\
\hline
\end{tabular}

${ }^{a}$ In grouping these genera the criteria of Rippka (1988) [53], Waterbury and Rippka (1989) [54], Waterbury (1989) [55] and Castenholz (1989) [56] were followed as far as possible. Genera listed in bold type possess strains that are capable of aerobic $\mathrm{N}_{2}$ fixation. However, with the possible exception of Gloeothece, this does not mean that every member of that genus can fix $\mathrm{N}_{2}$ aerobically.

${ }^{b} \mathrm{~N}_{2}$-fixing strains referred as Gloeocapsa prior to 1979 were designated as Gloeothece [22]. The name Gloeocapsa is used here for recent isolates identified as belonging to this genus. It should, however, be pointed out that the taxonomic difference between Gloeothece and Gloeocapsa is subtle: cells of Gloeothece divide in one plane, those of Gloeocapsa divide in two or three planes. This distinction is often difficult to observe in laboratory cultures. For example, the axes of individual cells of Gloeothece, though not the planes of division, can shift during cell division. In field samples identification is even more difficult.

${ }^{\mathrm{c}}$ Includes $\mathrm{N}_{2}$-fixing strains referred to as Aphanothece or Synechococcus (for example, strains PCC 7418, 7424 and 7425, RF-1, BG 43511 and 43522). The Cyanothece group is superficially distinguished from the Synechococcus group by cell size (3-6 $\mu$ m diameter as opposed to usually less than $2 \mu \mathrm{m}$ diameter) and from the Gloeothece group by the lack of a clearly defined, mucilaginous, multi-layered sheath. However, since sheathless strains have been derived from laboratory cultures of Gloeothece ([57-60]; Shestakov et al, unpublished) the taxonomic difference between Cyanothece and Gloeothece is blurred.

${ }^{\mathrm{d}}$ Only one strain of Synechococcus, strain PCC 7335, can fix $\mathrm{N}_{2}$.

${ }^{\text {e }}$ Two marine Synechocystis strains (one previously designated Erythrosphaera marina [32]) can fix $\mathrm{N}_{2}$ aerobically. They have very exacting growth requirements and have not been widely studied.

${ }^{\mathrm{f}}$ The LPP group includes the genera Lyngbya, Phormidium and Plectonema. The characteristics that define these individual genera have proved to be variable in culture, so the detailed taxonomy of this group is currently uncertain. Lyngbya majuscula [36] and L. aestuarii [37] have been reported to fix $\mathrm{N}_{2}$ aerobically: the latter may be identical to Oscillatoria limosa [42]. The marine Oscillatoria UCSB25 described by Gallon et al. (1991) [46] is probably also a strain of Lyngbya. Many strains designated as Plectonema or Phormidium can fix $\mathrm{N}_{2}$ under anoxic or micro-oxic conditions. Plectonema boryanum and some strains of Phormidium have been reassigned to the genus Leptolyngbya [4].

${ }^{\mathrm{g}}$ The strain of Microcoleus chthonoplastes that can fix $\mathrm{N}_{2}$ aerobically [38] differs from other strains of Microcoleus and has recently been assigned to the genus Symploca.

${ }^{\mathrm{h}}$ Includes LPP PCC 7409 which has been regrouped as Pseudanabaena PCC 7409 [24].

ular non-heterocystous cyanobacteria have been subjected to intense laboratory scrutiny. This has been directed especially at the mechanisms by which they protect nitrogenase from inactivation by both atmospheric and photosynthetically generated $\mathrm{O}_{2}$, but also at the way in which photosynthesis and respiration might generate the reductant and ATP needed to sustain $\mathrm{N}_{2}$ fixation.

The present article attempts to review and summarise the current state of knowledge gained from laboratory and field studies of $\mathrm{N}_{2}$ fixation in nonheterocystous cyanobacteria. This topic has pre- 


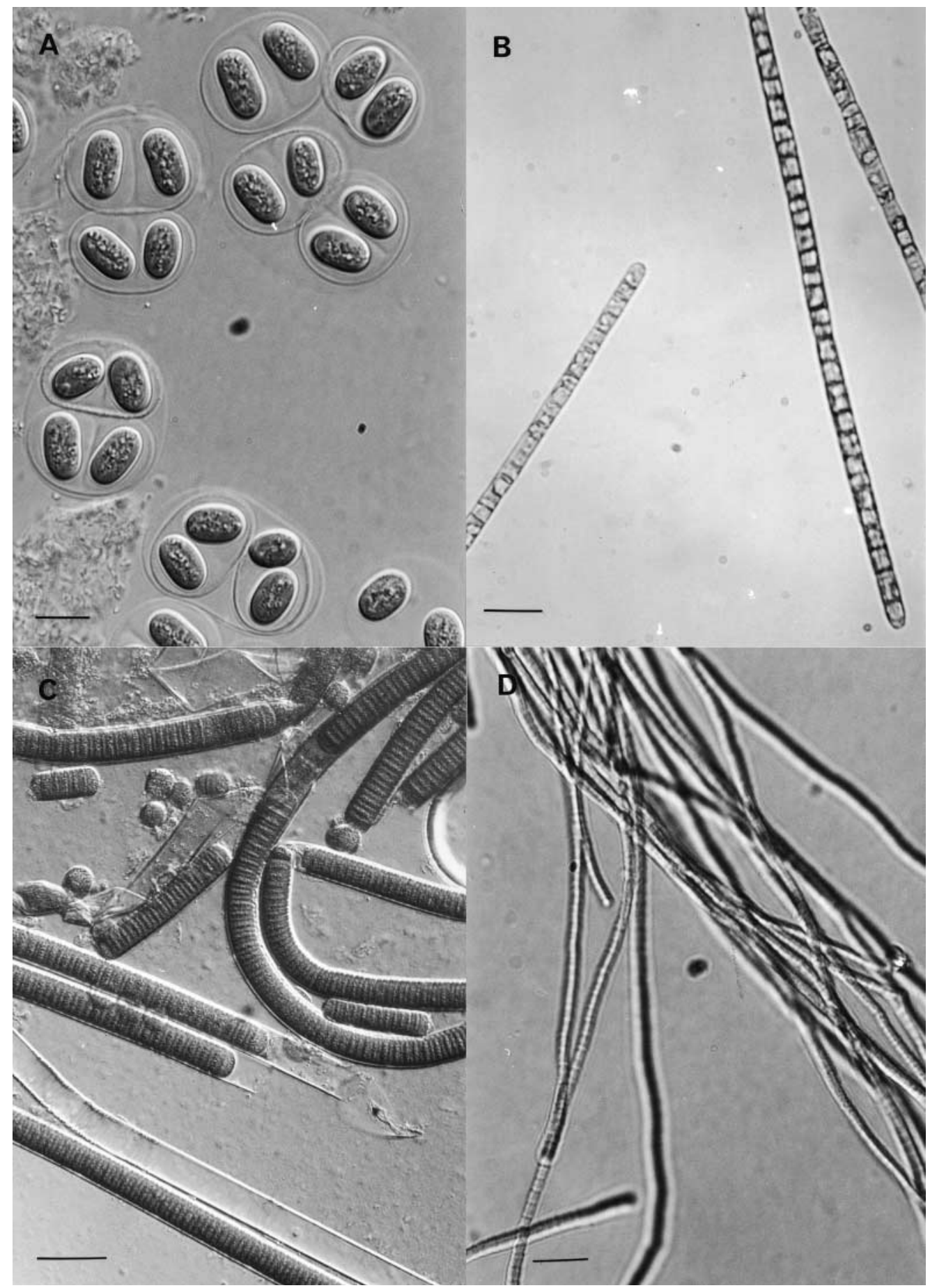

Plate 1. Some $\mathrm{N}_{2}$-fixing non-heterocystous cyanobacteria. (a) Gloeothece strain PCC 6909. Bar $=10 \mu \mathrm{m}$. (b) Trichodesmium strain IMS 101 [61]. Bar $=20 \mu \mathrm{m}$. (c) Oscillatoria limosa. Bar $=200 \mu \mathrm{m}$. (d) Plectonema boryanum PCC 73110. Bar $=10 \mu \mathrm{m}$. 
Table 2

Non-heterocystous cyanobacteria in diazotrophic symbioses

\begin{tabular}{lll}
\hline Symbiosis & Cyanobiont & References \\
\hline Rhopalodia:cyanobacteria & Thin-walled unicells ${ }^{\mathrm{a}}$ & {$[75,76] ;$ also see Plate 2 } \\
Marine sponges:cyanobacteria & Unicells $($ Aphanocapsa) & {$[77,78]$} \\
Fungi:cyanobacteria $^{\mathrm{b}}$ (cyanolichens) & Gloeocapsa, Gloeothece, Hyella $^{[79]}$ & \\
\hline
\end{tabular}

${ }^{a}$ These occur intracellularly and resemble unicellular cyanobacteria. None have been cultured or taxonomically characterized.

${ }^{\mathrm{b}}$ Aphanocapsa is not recognized as a distinct genus by Rippka et al. (1979) [22] or Rippka (1988) [53], who designate Aphanocapsa strains as Synechocystis. However, since these cyanobionts have not been cultured in the laboratory, their taxonomic status is unknown.

${ }^{\mathrm{c}} \mathrm{A}$ large number of cyanolichens, mostly belonging to the Lichinaceae and Heppiaceae, have unicellular cyanobacteria as cyanobionts (see [79]). Most cyanobionts resemble GloeocapsalGloeothece [80]. However, it is not certain whether such lichens fix $\mathrm{N}_{2}$.

viously been reviewed by Gallon and Stal (1992) [6], but a number of other recent reviews are relevant to this topic. These include the reviews of Fay (1992) [7] and Gallon (1992) [8] on the interrelations between $\mathrm{N}_{2}$ fixation and $\mathrm{O}_{2}$ in cyanobacteria and other diazotrophs and the more specialized reviews of Huang and Grobbelaar (1995) [9] on Synechococcus (Cyanothece) RF-1, Bergman et al. (1994) [10], Zehr (1995) [11] and Gallon et al. (1996) [12] on Trichodesmium, Stal (1995) [13] on cyanobacteria in microbial mats and Rai (1990) [14] on symbiotic cyanobacteria.

\section{Non-heterocystous cyanobacteria capable of $\mathbf{N}_{2}$ fixation}

Diazotrophic non-heterocystous cyanobacteria are conventionally grouped into unicellular and filamentous forms (Table 1). Some representative strains are illustrated in Plate 1. The taxonomy of cyanobacteria has undergone considerable revision over the past few years [22,53-57] and is still by no means definitive. Consequently, many of the organisms referred to in this review have been subjected to at least one change of name since first isolated and studied. Further alterations in nomenclature may reasonably be anticipated. Readers studying the primary literature for the first time are therefore strongly advised to check strain numbers (if quoted) very carefully before assuming that two cyanobacteria with different names are really different organisms. There is also a widespread feeling among workers in the field that some strains, currently believed to be different, may in reality represent independent isolates of the same organism. Use of modern techniques of molec- ular taxonomy, such as sequencing of 16S rRNA and related hyper-variable internally transcribed spacer regions in the genome, will be invaluable in resolving many of the current uncertainties (for an excellent revue, see [62]). Meanwhile, we have opted to use the names by which the organisms are currently most widely known, quoting synonyms where appropriate. For details, please see the footnotes to Table 1.

Unicellular cyanobacteria can be subdivided into two sections. Section I consists of genera reproducing by binary fission or budding while Section II consists of those reproducing either by multiple fission giving rise to small daughter cells (baeocytes) or by both multiple and binary fission. Among members of Section $\mathrm{I}$, aerobic $\mathrm{N}_{2}$ fixation was first reported in Gloeothece [2] followed by Aphanothece pallida (now Cyanothece sp) [21,29]. Subsequently, Rippka and Waterbury (1977) [18] reported aerobic $\mathrm{N}_{2}$ fixation in five strains of Gloeothece (all deposited in the Pasteur Culture Collection as PCC 6501, 6909, 7109, 73107 and 73108); a sixth (PCC 8302) was added later [57]. These strains have all been given the species name Gloeothece membranacea. One such strain is shown in Plate 1a. Since then, aerobic $\mathrm{N}_{2}$ fixation has been reported in Gloeocapsa [15-17], the marine unicellular cyanobacterium Erythrosphaera marina [32] (probably a strain of Synechocystis) and several Synechococcus strains [23,25,2730]. The latter are almost certainly Cyanothece spp, and include the rice field isolate Synechococcus RF-1 [19] and marine strains such as Synechococcus strains SF1 [27], BG 43511 and 43522 [23]. Three Synechococcus strains, two rice field isolates (PCC 7424 and 7425 ) and one marine isolate (PCC 7335), were reported to fix $\mathrm{N}_{2}$ only under anoxic conditions [18]. 

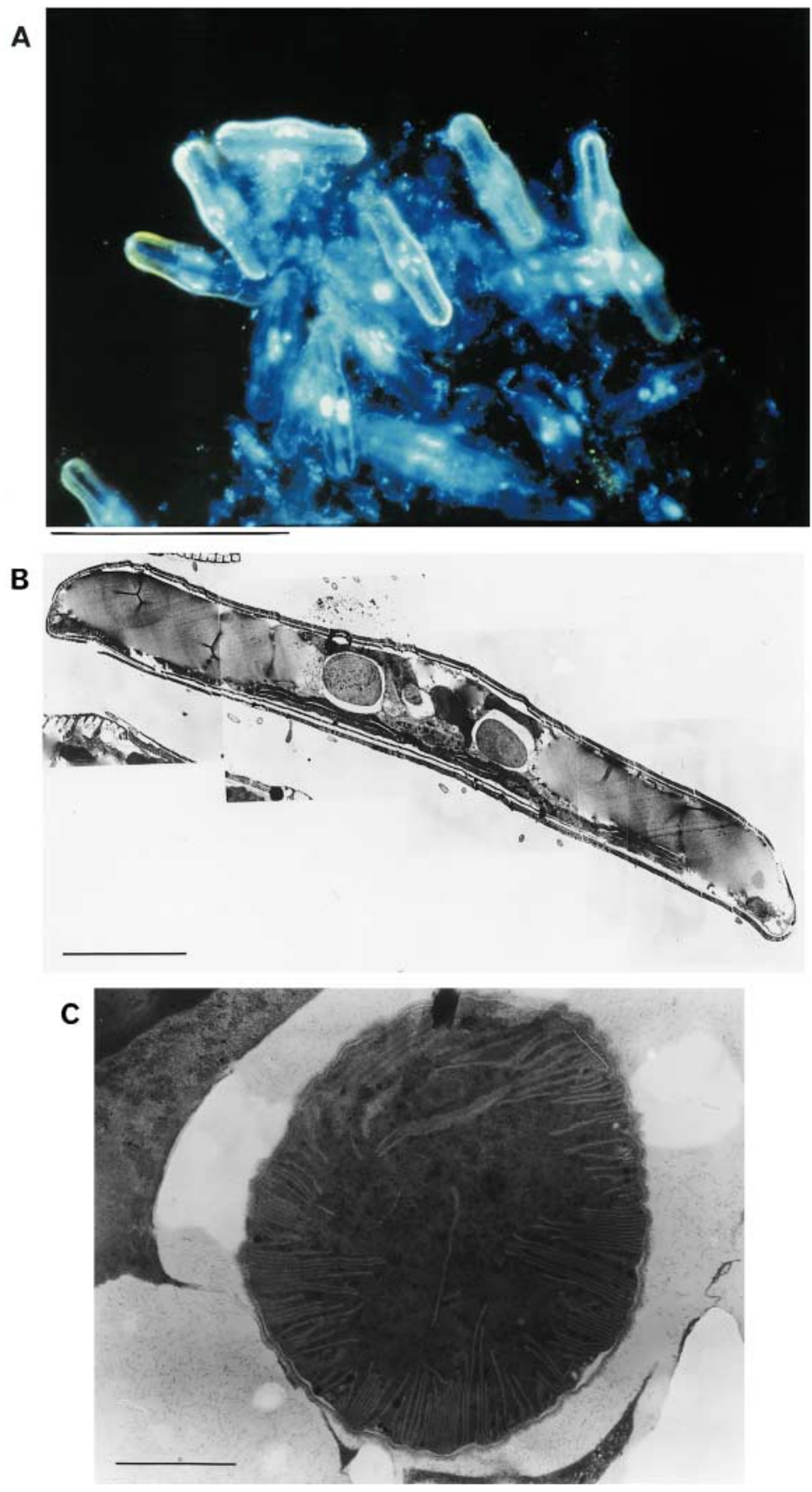

Plate 2. The freshwater diatom Rhopalodia gibba. The photographs show: (a) an epifluorescence micrograph stained with the DNA-binding fluorescent dye 4',6-diamidino-2-phenylindole (DAPI), showing (centre) a diatom with four fluorescing symbionts and a nucleus; (b) an electron micrograph of an intact diatom; and (c) a magnified view of a cyanobacterial-like symbiont. Size bars represent (a) $100 \mu \mathrm{m}$, (b) $10 \mu \mathrm{m}$ and (c) $1 \mu \mathrm{m}$. Photographs kindly provided by Dr H.R. DeYoe, National Estuary Program, Texas A and M University, Corpus Christi, TX, USA. 
Although one of these, Synechococcus PCC 7424 has been reported to be capable of aerobic $\mathrm{N}_{2}$ fixation (Rippka, unpublished results, quoted in [24]), it appears as a strain capable of $\mathrm{N}_{2}$ fixation only under anoxic conditions in the classification of Waterbury and Rippka (1989) [54]. Both PCC 7424 and 7425, along with Synechococcus PCC 7418 (formerly Aphanothece halophytica) are now classified as Cyanothece strains [54]. Another two strains of Cyanothece, designated BH63 and BH68 (now deposited in the American Type Culture Collection as ATCC 51141 and 51142 respectively), were reported by Reddy et al. (1993) [31]. Synechococcus PCC 7335 remains as the only $\mathrm{N}_{2}$-fixing cyanobacterium currently still assigned to this genus [54].

Two strains of Synechocystis, WH 8501 and 8502, both marine, can fix $\mathrm{N}_{2}$ aerobically. In addition, in at least one freshwater strain, Synechocystis BO 8402 , synthesis of nitrogenase can be induced by anoxic incubation in nitrogen-free medium [33,34].

Section I of the unicellular cyanobacteria includes an unusual organism, Gloeobacter violaceus [63]. This cyanobacterium resembles Gloeothece, but lacks photosynthetic thylakoids: the photosynthetic apparatus is confined to the plasma membrane. $G$. violaceus cannot fix $\mathrm{N}_{2}$, nor is nitrogenase synthesis induced under anoxic conditions [22,63]. Nevertheless there is a more recent report that this organism can grow aerobically in nitrogen-free medium [64]. This latter observation was not, however, accompanied by measurements of $\mathrm{N}_{2}$ fixation, so it would be premature to reclassify $G$ violaceus as a diazotroph. It is not, therefore, included in Table 1.

In Section II, 19 strains (10 marine) are known to synthesize nitrogenase but only under anoxic conditions [18,22]. These include all strains of Chroococcidiopsis examined (PCC 6712, 7203, 7431, 7432, 7433, 7434, 7436 and 7439), two strains of Dermocarpa (PCC 7301 and 7303), one strain of Myxosarcina (PCC 7312), one strain of Xenococcus (PCC 7305) and seven strains of the Pleurocapsa group (PCC 7314, 7320, 7321, 7322, 7324, 7327 and 7516). Of these Dermocarpa PCC 7301 and 7303, Myxosarcina PCC 7312, Xenococcus PCC 7305 and six strains of the Pleurocapsa group (PCC 7314, 7320, 7321, 7322, 7324 and 7516) were isolated from marine habitats.

Among filamentous forms, aerobic $\mathrm{N}_{2}$ fixation has been reported in several species of Trichodesmium,
[1,49,51,52,65-68], Microcoleus chthonoplastes [38,69], Oscillatoria limosa [42], Oscillatoria sp. [43], Oscillatoria sp. strains UCSB8 and UCSB25 [46], Lyngbya majuscula [36] and L. aestuarii (probably identical to Oscillatoria limosa: see Section 6.2.2 [37]. All are marine forms. A laboratory strain of Trichodesmium [61], now designated strain IMS 101, and Oscillatoria limosa are shown in Plate $1 \mathrm{~b}, \mathrm{c}$, respectively. The original $\mathrm{N}_{2}$-fixing strain of Microcoleus chthonoplastes [38] has recently been reassigned to the genus Symploca, whilst Oscillatoria sp. UCSB25 has been reidentified as a strain of Lyngbya (N. Anand, personal communication). In addition, there are several strains that fix $\mathrm{N}_{2}$ only under micro-oxic or anoxic conditions $[3,18,35,70]$. These include Phormidium foveolarum, 15 strains of the LPP group (PCC 6306, 6402, 6409, 7004, 7104, 7113, 7124, 7375, 7406, 7408, 7410, 7419, 7424, 7505 and 73110), five strains of Pseudanabaena (PCC 6406, 6802, 7403, 7409, and 7429), and five strains of Oscillatoria (PCC 6407, 6412, 6506, 6602 and 7515). To these can be added Oscillatoria chalybea [47] and the phycoerythrin-rich strains epiphytic on pelagic Sargassum [45]. All are freshwater forms except for LPP group strains PCC 7124, 7375 and 6419 and the Oscillatoria strains from Sargassum, which are marine. One of the LPP group strains, Plectonema boryanum, is shown in Plate $1 \mathrm{~d}$.

Mutants of heterocystous cyanobacteria have been reported that fail to produce heterocysts $\left(\right.$ het $^{-}$), yet retain the ability to fix $\mathrm{N}_{2}$ when incubated under micro-oxic or anoxic conditions [71,72]. Although, taxonomically, these mutant cyanobacteria would not be classified as non-heterocystous, physiologically they may have much in common with their non-heterocystous relatives. However, these het ${ }^{-}$ mutants would appear to be unusual. Most het ${ }^{-}$ mutants cannot fix $\mathrm{N}_{2}[73,74]$.

Some non-heterocystous cyanobacteria have been reported to form symbiotic associations (Table 2). The cyanobacterial partner in these symbioses is referred to as a cyanobiont. The freshwater diatom Rhopalodia (Plate 2) contains thin-walled unicells resembling cyanobacteria that have been shown to fix $\mathrm{N}_{2}[75,76]$. Unicellular cyanobacteria are also known from the marine diatom Streptotheca sp., but it is uncertain whether this association fixes $\mathrm{N}_{2}$ [78]. Aphanocapsa (probably Synechocystis) and Phormi- 

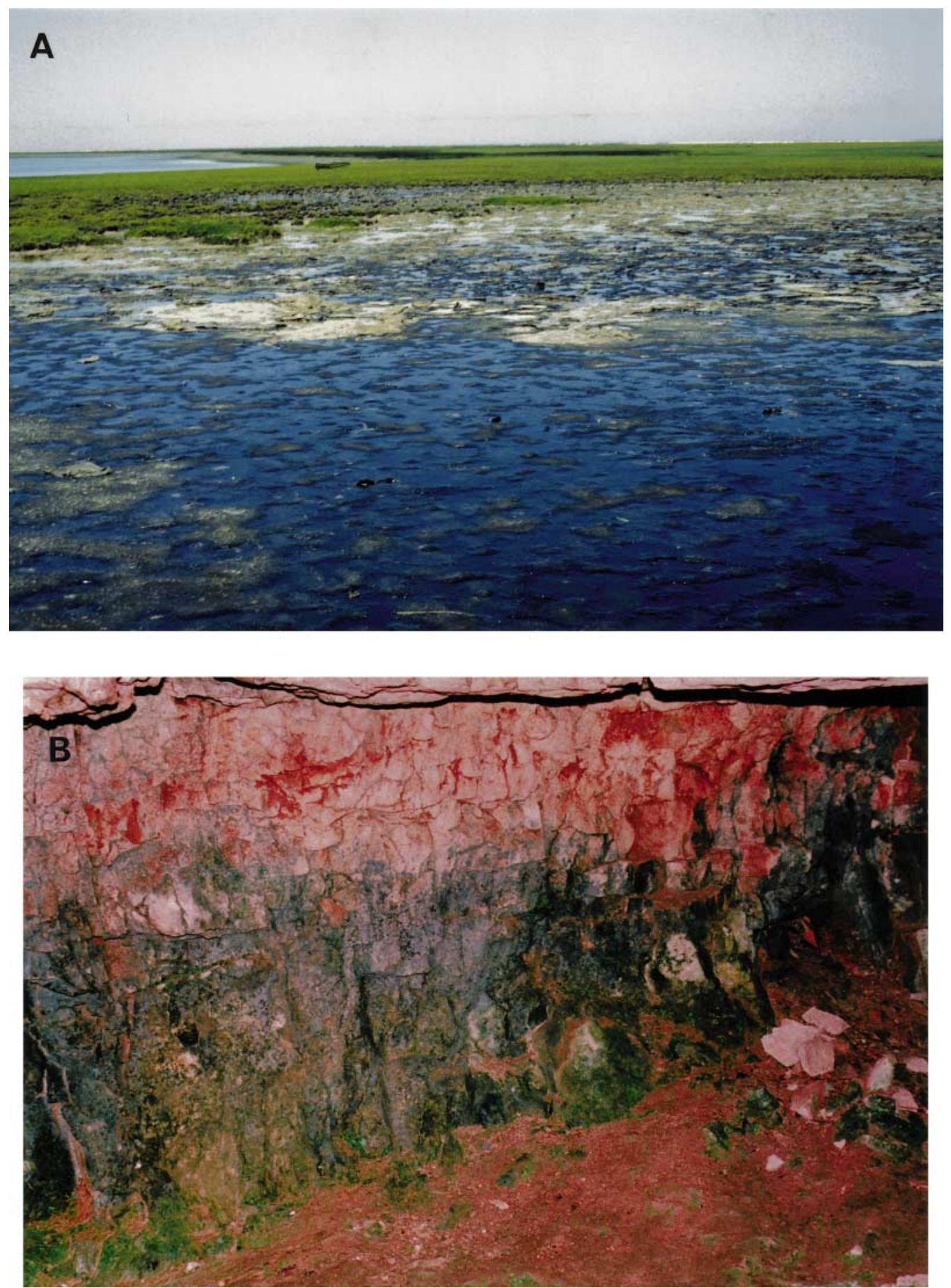

Plate 3. Some natural populations of non-heterocystous cyanobacteria. (a) Microbial mats in Baja California, Mexico. The smooth mat (foreground) is composed of cyanobacteria of the LyngbyalOscillatoria type. (b) Cyanobacteria on the wall of a limestone cave near Swansea, Wales: a population dominated by Gloeothece. (c) An aerial photograph of a bloom of Trichodesmium off Hawaii. Photograph courtesy of Dr R. Letelier and Dr D.M. Karl, Hawaii Ocean Time-Series Team, University of Hawaii, Honolulu, Hawaii, USA. (d) Part of a Trichodesmium bloom from sea level (acknowledgements as c). 

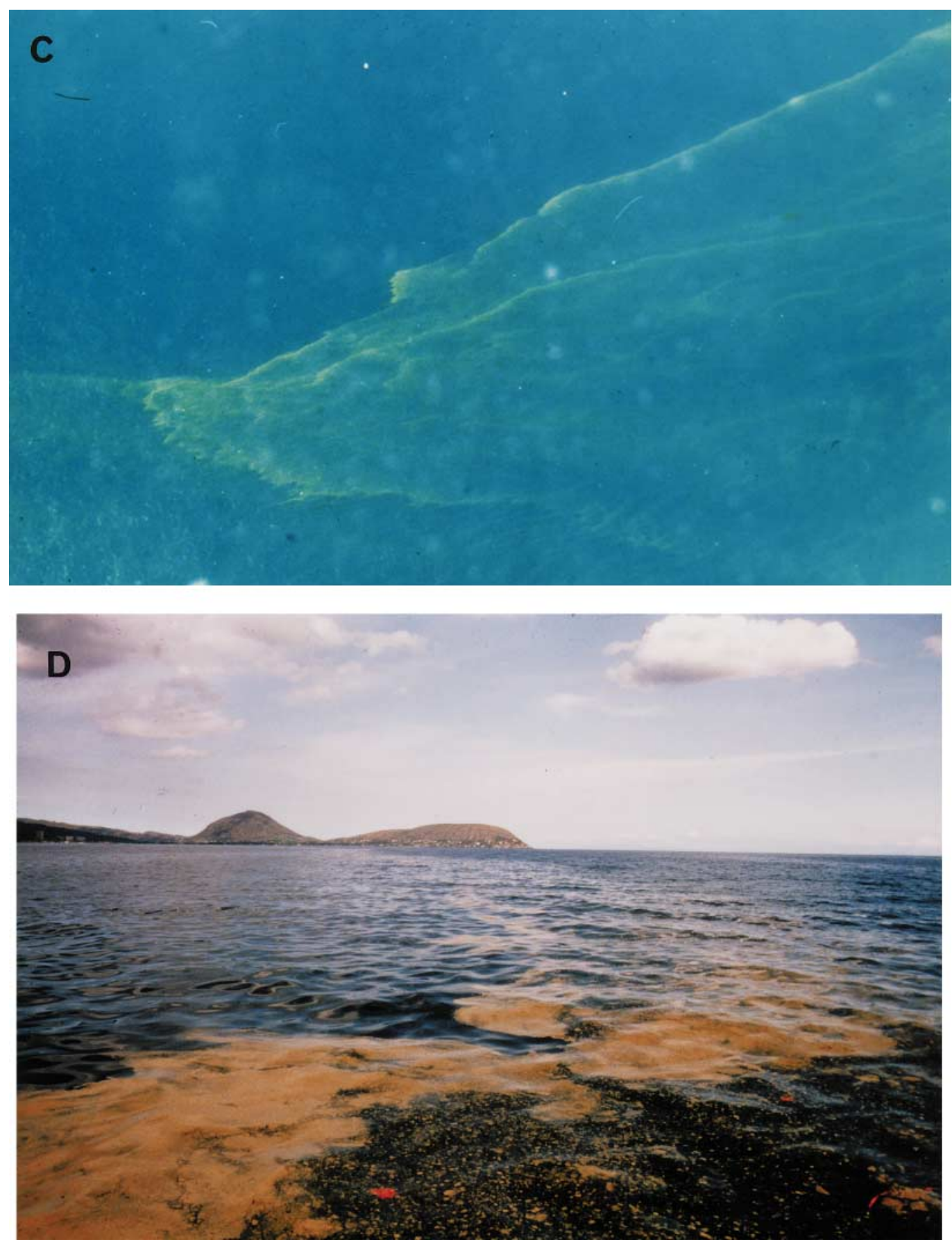

Plate 3 (continued).

dium have been reported as cyanobionts in 38 genera of marine sponges belonging to the Calcarea and
Desmospongia (see [14]). In at least two cases, Thionella swinhoei and Siphonochalina tabernacula, the 

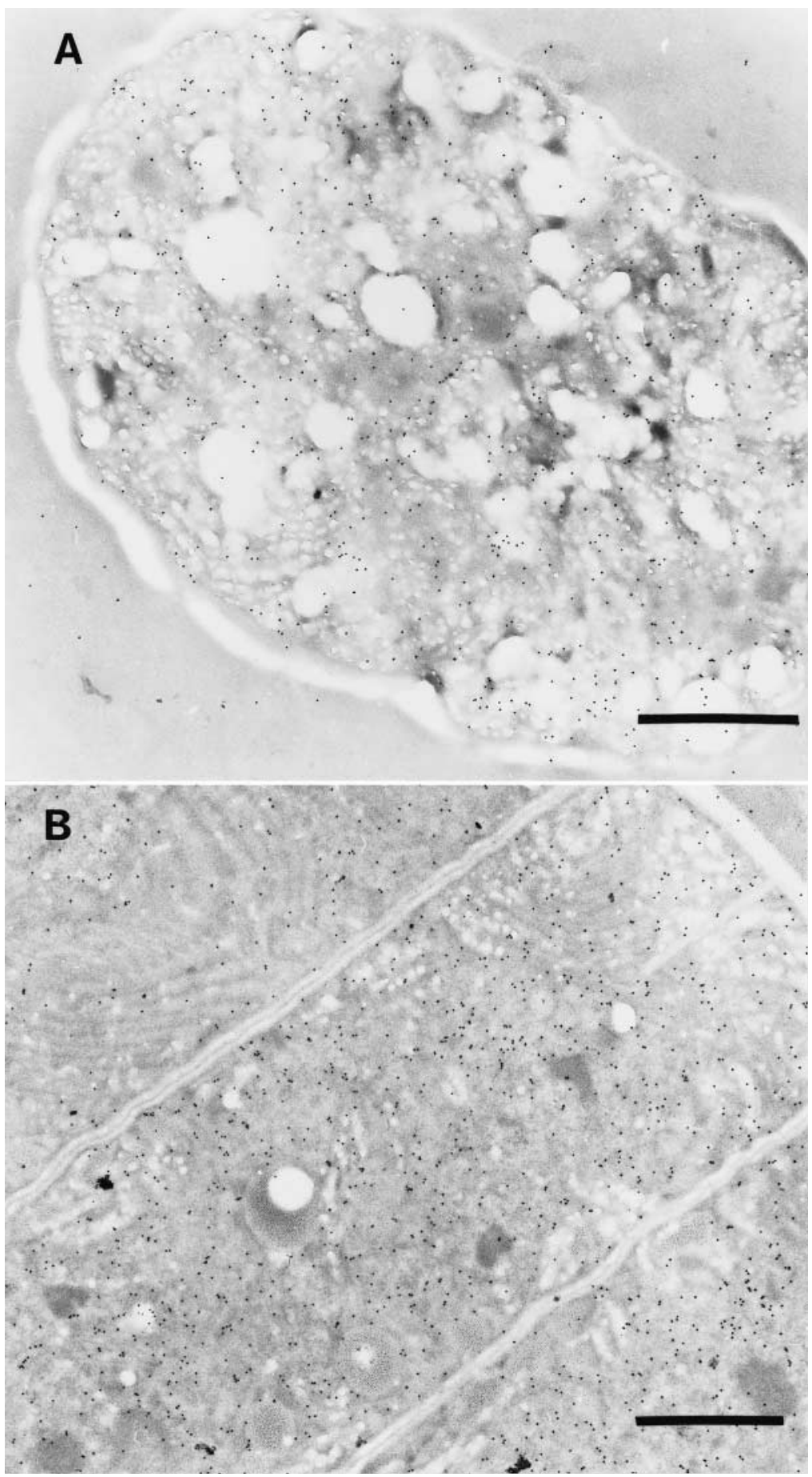

Plate 4. 


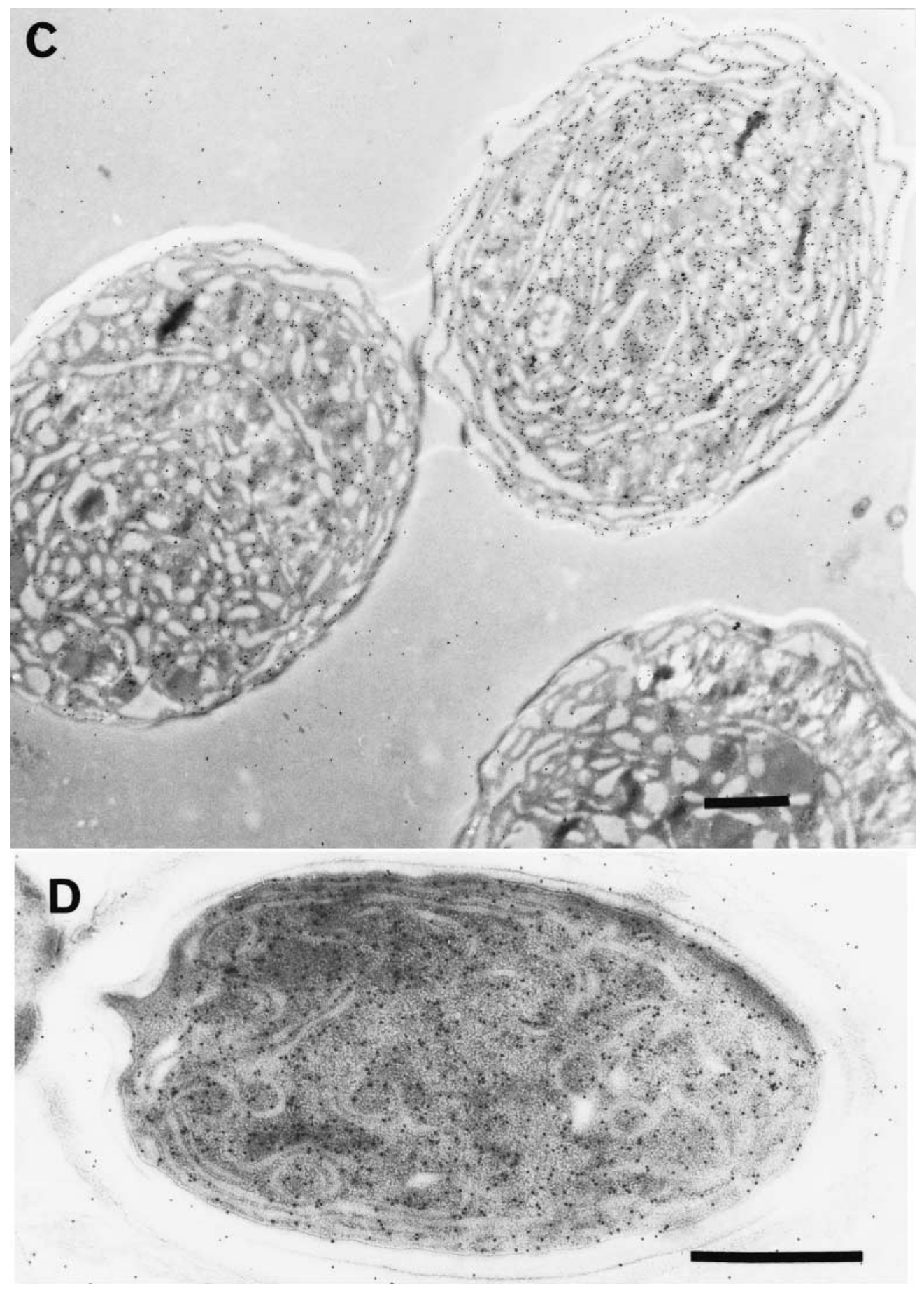

Plate 4 (continued). 
Plate 4. Immunolocalization of the Fe-protein of nitrogenase in various $\mathrm{N}_{2}$-fixing cyanobacteria. (a) The unicellular cyanobacterium Gloeothece strain PCC 6909. (b) A longitudinal section of the filamentous mat-forming organism Oscillatoria limosa [42]. (c) A transverse section of the filamentous marine cyanobacterium Trichodesmium sp. (d) For comparative purposes, the cellular location of Fe-protein is also shown in a heterocyst of the heterocystous cyanobacterium, Nostoc sp. PCC 9229, isolated from symbiosis with the angiosperm Gunnera. Size bar $=1 \mu \mathrm{m}$ throughout. Note that nitrogenase is evenly distributed within all cells of Gloeothece and $O$. limosa (a,b), but that the intensity of immunogold labelling varies considerably between individual cells of Trichodesmium. For example, intense labelling is seen in the cross-sectioned cell in the upper right-hand corner of (c), whilst the cell at the bottom of the photograph shows no labelling at all. In Nostoc (d), Fe-protein is detected only in heterocysts.

$\leftarrow$

cyanobiont has been shown to fix $\mathrm{N}_{2}$ [77]. Unicellular cyanobacteria variously described as Gloeocapsa, Gloeothece and Hyella (a genus that has been assigned to the Pleurocapsa group) have been reported

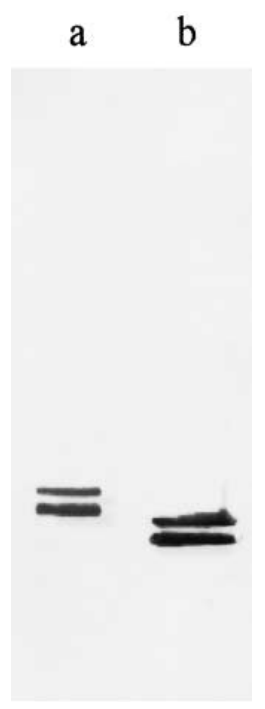

Fig. 1. Two forms of the Fe-protein of nitrogenase in extracts of (a) Gloeothece and (b) Rhodospirillum rubrum. Track a shows an extract of Gloeothece prepared from cells sampled $2 \mathrm{~h}$ into the dark phase of a cycle of alternating $12 \mathrm{~h}$ light and $12 \mathrm{~h}$ darkness after SDS/PAGE and Western blotting. The Fe-protein was detected using antisera raised against the Fe-protein of nitrogenase from the photosynthetic bacterium Rhodospirillum rubrum. For further details see [60]. Track $b$ shows a sample of ADP-ribosylated Fe-protein of nitrogenase from $R$ r rubrum. The upper band of the Fe-protein from $R$. rubrum represents the ADP-ribosylated subunit; the lower band $\left(M_{\mathrm{r}}=32500\right.$; [137]) is unmodified. The upper band of the Fe-protein from Gloeothece has an apparent $M_{\mathrm{r}}$ of 40000 and is presumed to be a modified form of the lower, presumed unmodified, band (apparent $M_{\mathrm{r}}=38500$ ). The nature of the modification is unknown but is unlikely to involve ADP-ribosylation (see text). Antisera and $R$. rubrum Feprotein were kindly provided by Prof P. Ludden, University of Wisconsin, Madison, Wisconsin, USA. Photograph courtesy of Dr. J. Cheng, Biochemistry Research Group, University of Wales Swansea, Swansea, UK.
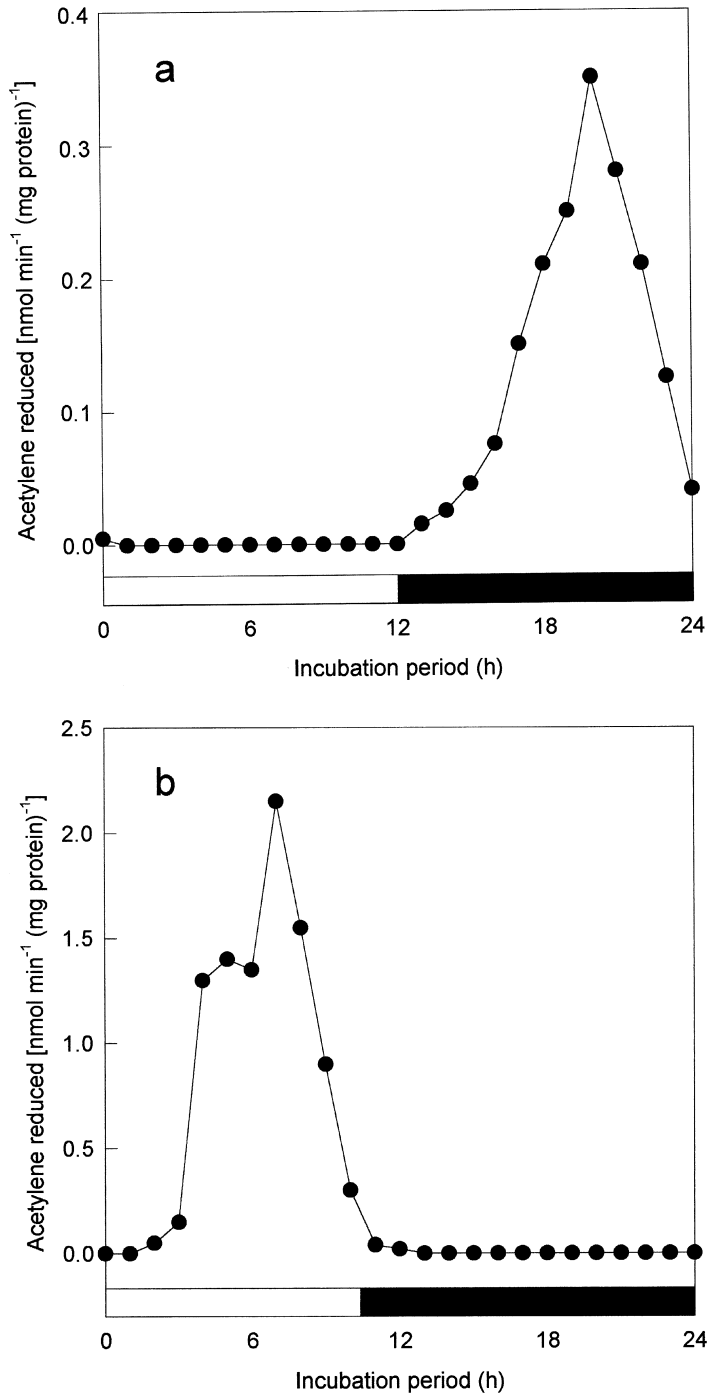

Fig. 2. The pattern of $\mathrm{N}_{2}$ fixation in (a) laboratory cultures of Gloeothece grown under alternating $12 \mathrm{~h}$ light and $12 \mathrm{~h}$ darkness and (b) natural populations of Trichodesmium, sampled in the Eastern Caribbean Sea in January 1992. In b, zero time corresponds to sunrise. Day length was approximately $10.5 \mathrm{~h}$. 
Table 3

Relative amounts and activities of nitrogenase in heterocysts of Anabaena cylindrica and in non-heterocystous cyanobacteria

\begin{tabular}{lll}
\hline & Amount of nitrogenase $^{\mathrm{a}}$ & Nitrogenase activity $^{\mathrm{b}}$ \\
\hline Heterocysts & $50 \pm 8(3-4)^{\mathrm{c}}$ & $10-12^{\mathrm{d}}$ \\
Oscillatoria limosa & $54 \pm 6$ & $12-15$ \\
Plectonema boryanum & $47 \pm 6$ & $10-15$ \\
Gloeothece strain PCC 6909 & $42 \pm 5$ & $6-8$ \\
\hline
\end{tabular}

${ }^{a}$ Values for the amount of nitrogenase represent labelling densities (number of gold particles per $\mu \mathrm{m}^{2}$ area) obtained in immunogold labelling experiments using primary antibodies (1:100 dilution) raised in rabbits against the Fe-protein of the nitrogenase of Rhodospirillum rubrum, and secondary antibodies raised in goats against rabbit IgG and conjugated to colloidal gold particles (10 nm diameter).

${ }^{\mathrm{b}} \mathrm{nmol}$ acetylene reduced $\mathrm{h}^{-1}(\mu \mathrm{g} \operatorname{chl} a)^{-1}$.

${ }^{\mathrm{c}}$ Figures in brackets represent the value obtained when heterocyst labelling is expressed per unit cell area, taking into account vegetative cells as well as heterocysts.

${ }^{\mathrm{d}}$ The specific activity of nitrogenase relates to whole filaments (i.e. to both vegetative cells and heterocysts).

as cyanobionts from several lichens, mainly of the families Lichinaceae and Heppiaceae (see [79,80]). Although the cyanobionts from such lichens have not been tested for nitrogenase activity, several other strains of these genera are known to fix $\mathrm{N}_{2}$ (see Table 1).

\section{3. $\mathbf{N}_{2}$ fixation by non-heterocystous cyanobacteria in the natural environment}

\subsection{Microbial mats}

Marine intertidal sediments are often characterized by the development of dense communities of cyanobacteria referred to as microbial or cyanobacterial mats [81]. An example is shown in Plate 3a. Because the marine environment is low in combined nitrogen, the development of microbial mats is possible only due to the activity of $\mathrm{N}_{2}$-fixing organisms. The majority of microbial mats are composed of Microcoleus chthonoplastes. Because mats of $M$. chthonoplastes have been repeatedly reported to fix $\mathrm{N}_{2}$, this cyanobacterium was thought to be the $\mathrm{N}_{2}$-fixing agent [38,82-87]. Moreover, it has been suggested that formation of bundles of trichomes enclosed by a polysaccharide sheath, which characterizes $M$. chthonoplastes, protects nitrogenase against inactivation by $\mathrm{O}_{2}$ [83]. However, cultures of this organism were not capable of diazotrophic growth under oxic conditions [40]. Nevertheless, Pearson et al. (1979) isolated a non-heterocystous diazotrophic cyanobacterium that they identified as M. chthonoplastes [38].
They showed that neither bundle formation nor the polysaccharide sheath was necessary for aerobic diazotrophic growth. However, this organism is now considered to be a strain of Symploca (Table 1). $M$. chthonoplastes isolated from North Sea microbial mats expressed nitrogenase activity in laboratory culture only under anoxic conditions in the light [40]. Although such behaviour can be found in a large number of cyanobacteria [18], in most cases its ecological relevance is not clear. Nevertheless, preliminary experiments, designed to study microbial mat formation in the laboratory, have provided some evidence that nitrogenase is expressed in $M$. chthonoplastes following immobilization on sea sand (R.T. Carius and L.J. Stal, unpublished observations). It cannot therefore be excluded that $M$. chthonoplastes plays a role in $\mathrm{N}_{2}$ fixation in the natural environment. Immunogold localization of nitrogenase in natural samples would help to resolve this uncertainty.

Microbial mats with $M$. chthonoplastes as the dominant cyanobacterium often also contain other types of cyanobacteria. For instance in North Sea microbial mats, Oscillatoria limosa was usually the pioneer organism [81]. In culture, this cyanobacterium possesses the capacity for diazotrophic growth under fully oxic (aerobic) and photoautotrophic conditions [42]. Furthermore, the rate of acetylene reduction in the mat could be positively correlated with the amount of $O$. limosa present [88]. Although in well-established microbial mats $M$. chthonoplastes becomes the dominant cyanobacterium, $O$. limosa remains in considerable numbers. Indeed, $O$. limosa 
Figure 3. 'Autoprotection' of nitrogenase from inactivation by $\mathrm{O}_{2}$.

a. An overview

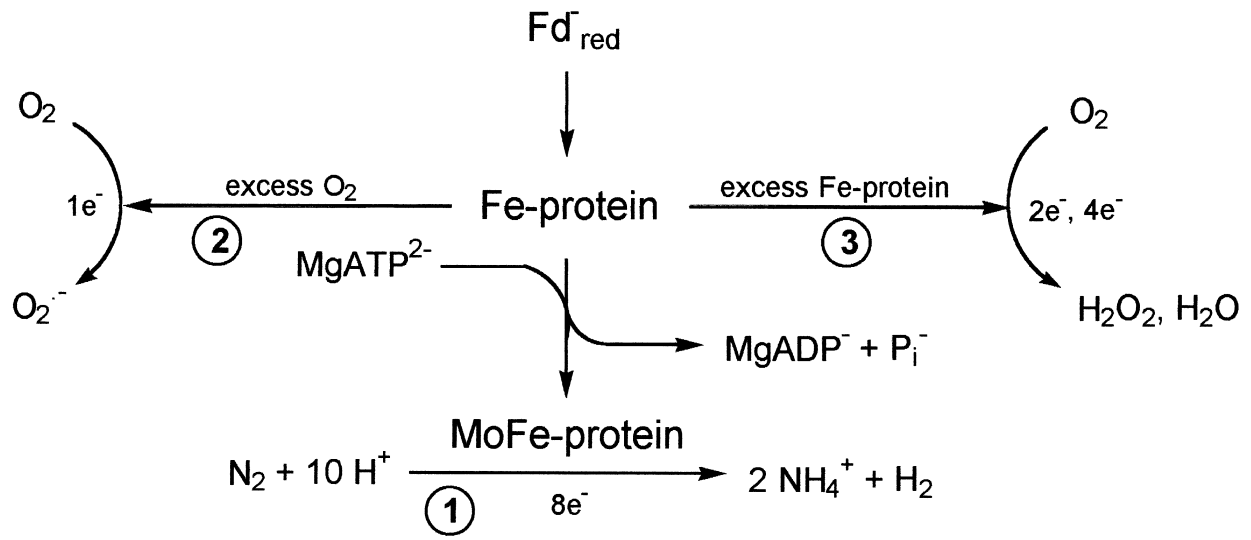

\section{b. Individual reactions}

Reaction 1: $\mathrm{N}_{2}$ fixation $[163,165]$

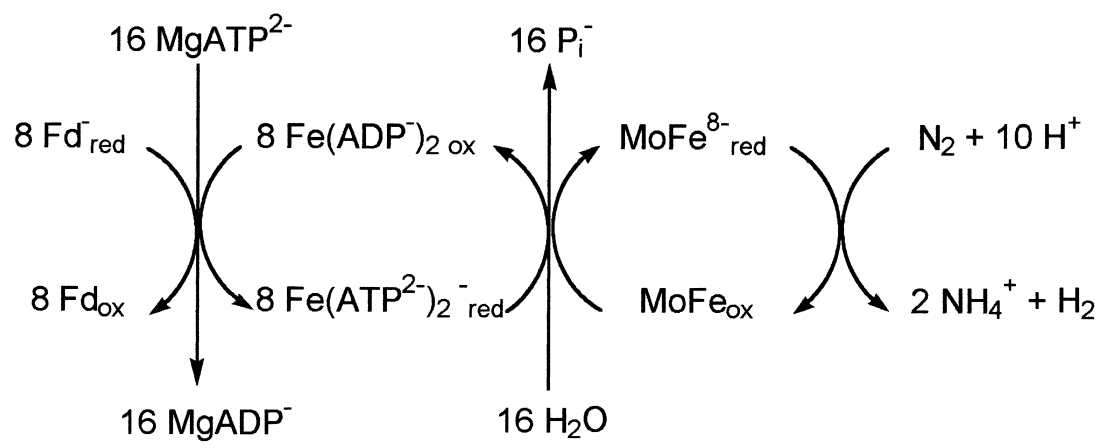

Reaction 2: Production of superoxide $\left(\mathrm{O}_{2}{ }^{-}\right)$[260]

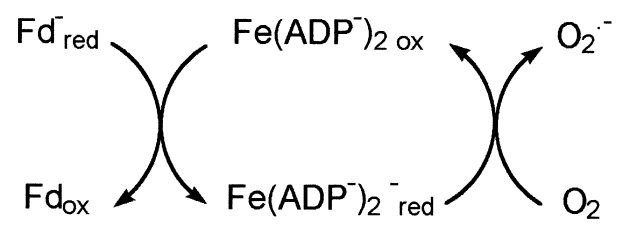

Fig. 3. 'Autoprotection' of nitrogenase from inactivation by $\mathrm{O}_{2}$. (a) An overview. (b) Individual reactions: Reaction 1: $\mathrm{N}_{2}$ fixation [163,165]; Reaction 2: production of superoxide $\left(\mathrm{O}_{2}^{-*}\right)$ [260]; Reaction 3: 'autoprotective' $\mathrm{O}_{2}$ consumption [260]. Fd = ferredoxin; $\mathrm{Fe}\left(\mathrm{ADP}^{-}\right)_{2}=\mathrm{Fe}$-protein $\left(\mathrm{MgADP}^{-}\right)_{2}$ complex; FeATP $\left.{ }^{2-}\right)_{2}=\mathrm{Fe}$-protein $\left.\mathrm{MgATP}^{2-}\right)_{2}$ complex; MoFe $=1 / 2 \mathrm{MoFe}-$ protein; $\mathrm{P}_{\mathrm{i}}^{-}=$ $\mathrm{H}_{2} \mathrm{PO}_{4 ;-} ; \mathrm{X}(\mathrm{XH})=$ Oxidized (reduced) form of a peroxidase substrate. 
Reaction 3: 'Autoprotective' $\mathrm{O}_{2}$ consumption [260]

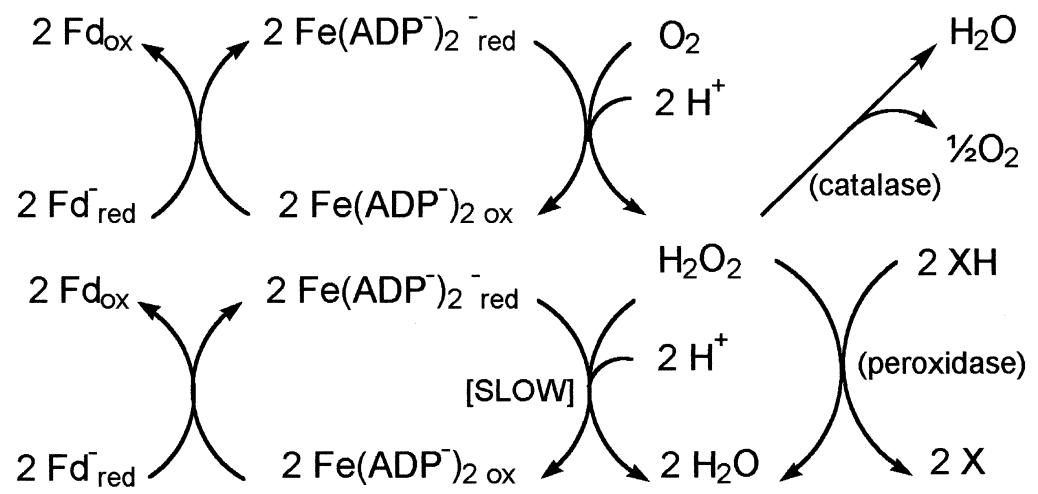

\section{Notes:}

$\mathrm{Fd}=$ ferredoxin; $\mathrm{Fe}\left(\mathrm{ADP}^{-}\right)_{2}=$ Fe-protein $\left(\mathrm{MgADP}^{-}\right)_{2}$ complex; $\mathrm{Fe}\left(\mathrm{ATP}^{2-}\right)_{2}=\mathrm{Fe}$-protein $\left(\mathrm{MgATP}{ }^{2-}\right)_{2}$ complex; $\mathrm{MoFe}=1 / 2 \mathrm{MoFe}-$ protein; $\mathrm{P}_{\mathrm{i}}^{-}=\mathrm{H}_{2} \mathrm{PO}_{4}{ }^{-}$; $\mathrm{X}(\mathrm{XH})=$ oxidized (reduced) form of a peroxidase substrate.

Fig. 3 (continued).

may even become dominant in established mats, probably depending on the nitrogen status of the system. Similarly, microbial mats on the North Carolina coast [89] and in intertidal flats near Guerrero Negro, Baja California, Mexico [90] are composed virtually solely of a single morphotype of cyanobacterium (Oscillatoria-Lyngbya type). These mats are all characterized by very high nitrogenase activities. Furthermore, a number of other reports on $\mathrm{N}_{2}$ fixation in marine tidal sediments mention Oscillatoria (Lyngbya) spp. as important organisms [84,87,91,92]. $\mathrm{N}_{2}$-fixing Lyngbya was also found in submersed mats on coral reefs [93]. From these reports it can be concluded that Oscillatoria spp. are probably the most important $\mathrm{N}_{2}$-fixing agents in marine sediments.

\subsection{Terrestrial and freshwater cyanobacteria}

The unicellular $\mathrm{N}_{2}$-fixing cyanobacterium Gloeothece can be found in soils [94], rice fields [19], sphagnum bogs [22] and on limestone cave walls
[92] (see Plate 3b). Very little is known about $\mathrm{N}_{2}$ fixation by natural populations of this cyanobacterium, though Griffiths et al. (1987) showed that Gloeothece growing on the wall of a limestone cave fixed $\mathrm{N}_{2}$ only during the night [92].

Several unicellular Cyanothece (Synechococcus or Aphanothece) strains that are capable of aerobic $\mathrm{N}_{2}$ fixation also occur in soils or freshwater environments $[16,19,28,95]$. In contrast, those filamentous non-heterocystous cyanobacteria that can fix $\mathrm{N}_{2}$ aerobically are mainly confined to marine or brackish habitats. However, several representatives of cyanobacterial genera that include strains capable of $\mathrm{N}_{2}$ fixation only under anoxic or micro-oxic conditions are found in terrestrial and freshwater environments. For example, Phormidium, Plectonema and Lyngbya strains are reported from stagnant pools and waterlogged soils [96]. In such relatively anoxic environments, they may be able to fix $\mathrm{N}_{2}$, but there have so far been no detailed studies on the environmental significance of $\mathrm{N}_{2}$ fixation by these strains. Synechococcus, Synechocystis and Oscillatoria strains 
are also abundant in fresh waters (see, for example, $[97,98])$ but, again, there are few reports of $\mathrm{N}_{2}$ fixation by these strains in situ. In general, the dominant $\mathrm{N}_{2}$-fixing cyanobacteria in soils and in fresh waters are heterocystous strains.

The diatom Rhopalodia, which lives in symbiosis with a thin-walled coccoid cyanobacterium (Table 2; Plate 2), is found in fresh water. Although this association is diazotrophic, the cyanobiont has not been isolated and it is not known to what extent this symbiotic association contributes to $\mathrm{N}_{2}$ fixation in the natural environment.

\subsection{Marine plankton}

Very small unicellular Synechococcus spp. are abundant in the marine plankton and make an important contribution to primary production in the oceans. Although a few $\mathrm{N}_{2}$-fixing unicellular cyanobacteria have been isolated from the marine environment $[32,99]$ there has been no systematic investigation of their contribution to the nitrogen budget of the marine environment. However, current data point to a minor contribution of picoplankton to $\mathrm{N}_{2}$ fixation. Virtually all strains that have been isolated are incapable of fixing $\mathrm{N}_{2}$. The small size of these organisms is probably an adaptation to the oligotrophic marine environment and their large surface area to volume ratio probably enables them to scavenge combined nitrogen more effectively than larger species.

Trichodesmium spp. are extremely abundant in the tropical and subtropical oceans with a salinity of approximately $35 \%$ and a water temperature above $25^{\circ} \mathrm{C}$. In these waters, this cyanobacterium can form massive blooms covering areas over $2 \times 10^{6} \mathrm{~km}^{2}$ ([100]; E.J. Carpenter and D.G. Capone, personal communication). Much smaller blooms are illustrated in Plate 3c,d. Blooms of Trichodesmium can readily be detected by remote imaging from orbiting satellites, giving Trichodesmium the unusual distinction of being a living organism that can be observed from space. There are occasional reports of Trichodesmium in the Mediterranean, where the temperature is usually lower than $25^{\circ} \mathrm{C}$, but no information is available on its physiological activity, including $\mathrm{N}_{2}$ fixation. The occurrence of Trichodesmium (usually in a moribund state) in the colder North Atlantic has been explained by transport from the tropical ocean.

Trichodesmium spp. occur as single trichomes $[101,102]$ and also as aggregates of variable size. Large aggregates may measure several millimetres and may contain hundreds of trichomes. The trichomes in the bundles may be orientated parallel to each other ('tufts') or radially ('puffs'). The density of the colony may vary. Although different types of colonies can be found in one population, comparatively little is known about possible differences in their physiology. On the other hand, Carpenter et al. (1993) demonstrated distinct differences in the physiology of two of the more commonly occurring species of Trichodesmium, T. thiebautii and T. erythraeum [50]. In addition, a recent survey clearly demonstrated that several different species of Trichodesmium exist and, under natural conditions, they often occur together [103]. Although laboratory cultures of Trichodesmium can fix $\mathrm{N}_{2}[61,104]$, these are not yet axenic. Moreover, in the natural environment, aggregates of Trichodesmium may be associated with chemotrophic $\mathrm{N}_{2}$-fixing bacteria [105] and with other filamentous non-heterocystous cyanobacteria [106]. However, the amount of nitrogenase detected in these associated organisms is negligible compared with that seen in Trichodesmium itself $[106,107]$. It therefore seems safe to conclude that this cyanobacterium is a true diazotroph.

As with other symbiotic systems, the environmental significance of $\mathrm{N}_{2}$ fixation in the two marine sponges, Thionella swinhoei and Siphonochalina tabernacula, remains unknown.

\section{Nitrogen budgets and rates of non-heterocystous $\mathbf{N}_{2}$ fixation}

Field studies on $\mathrm{N}_{2}$-fixing, non-heterocystous cyanobacteria have focused attention on their potential role in the nitrogen economy of a wide range of habitats in general and in marine ecosystems in particular. However, with the possible exception of Trichodesmium, very little is known about the contribution of $\mathrm{N}_{2}$ fixation by non-heterocystous cyanobacteria to the nitrogen budget of the systems where these organisms occur. The rates that are published are, in general, difficult to compare. For ex- 
ample, in most cases $\mathrm{N}_{2}$ fixation was determined using the acetylene reduction technique. The conversion of acetylene reduction to actual rates of $\mathrm{N}_{2}$ fixation cannot be done accurately without direct calibration using ${ }^{15} \mathrm{~N}_{2}$. The ratio of acetylene reduced to ${ }^{15} \mathrm{~N}_{2}$ fixed can vary. Furthermore, published rates of $\mathrm{N}_{2}$ fixation were usually derived from occasional measurements which did not take into account diel and seasonal variations. In addition, the quantitative measurement of $\mathrm{N}_{2}$ fixation in the natural environment is beset with methodological problems. We do not propose therefore to give a detailed overview of rates of $\mathrm{N}_{2}$ fixation and nitrogen budgets in environments dominated by non-heterocystous cyanobacteria. Rather, we confine ourselves to some general remarks.

$\mathrm{N}_{2}$ fixation by Trichodesmium spp. ranges from $0.002-0.04 \mathrm{~g} \mathrm{~N} \mathrm{~m}^{-2} \mathrm{yr}^{-1}$ [108] to up to $0.7 \mathrm{~g} \mathrm{~N}^{-0}$ $\mathrm{m}^{-2} \mathrm{yr}^{-1}$ [109]. Carpenter and Capone (1992) [67] calculate a total annual rate of $\mathrm{N}_{2}$ fixation of 5.4 $\mathrm{Tg} \mathrm{N}$ for blooms of Trichodesmium (assuming 20 blooms per year with an average surface area of $20000 \mathrm{~km}^{2}$ ) whilst Capone and Carpenter (1982) [110] have estimated global non-bloom $\mathrm{N}_{2}$ fixation to be $4.7 \mathrm{Tg} \mathrm{N} \mathrm{yr}^{-1}$. Estimates of total $\mathrm{N}_{2}$ fixation on Earth vary, but that of $170-270 \mathrm{Tg} \mathrm{N} \mathrm{yr}^{-1}$ recorded by Paul (1978) [111] appears reasonable. On this basis, it appears that Trichodesmium could contribute as much as $6 \%$ to global $\mathrm{N}_{2}$ fixation (see [12]). This compares with an estimated contribution of $20 \%$ for $\mathrm{N}_{2}$ fixation by legumes [112]. However, recent data indicate that estimates of $\mathrm{N}_{2}$ fixation by Trichodesmium could be as much as two orders of magnitude too low (D.G. Capone and E.J. Carpenter, personal communication). If so, the estimate of total $\mathrm{N}_{2}$ fixation on earth will need revising, and Trichodesmium could make a larger contribution to this total than all other sources of $\mathrm{N}_{2}$ fixation combined. It is also worth mentioning that $\mathrm{N}_{2}$ fixed by Trichodesmium enhances the productivity of other phytoplankton species [113].

Stal et al. (1984) calculated the contribution of $\mathrm{N}_{2}$ fixation by $O$. limosa on a North Sea intertidal flat to be, on average, $0.8-1.5 \mathrm{~g} \mathrm{~N} \mathrm{~m}^{-2} \mathrm{yr}^{-1}$ [88]. These rates were calculated from acetylene reduction rates using a conversion factor $\left(\mathrm{C}_{2} \mathrm{H}_{2}\right.$ reduced: $\mathrm{N}_{2}$ fixed) of $4: 1$, which is that predicted by theory. Diel and seasonal variations were also taken into account. For instance, if only the highest rates of acetylene reduction were used [114] and extrapolated, assuming $12 \mathrm{~h}$ day $^{-1}$ and 200 days $\mathrm{yr}^{-1}$ of activity, a figure of $9.6 \mathrm{~g}$ $\mathrm{N} \mathrm{m}^{-2} \mathrm{yr}^{-1}$ can be derived. These rates are among the highest reported [108]. It can therefore be concluded that communities of non-heterocystous cyanobacteria may contribute as efficiently to the nitrogen budget of an ecosystem as do heterocystous cyanobacteria. However, with the possible exception of Trichodesmium, the data on the distribution of non-heterocystous $\mathrm{N}_{2}$-fixing cyanobacteria and their contribution to the nitrogen budget are unfortunately too scarce to allow global extrapolation of their importance. Nevertheless, in general terms, it is likely that non-heterocystous cyanobacteria make a major contribution to the operation of the nitrogen cycle on earth.

\section{Nitrogenase in non-heterocystous cyanobacteria}

\subsection{Nitrogenase and the nif genes}

'Conventional' molybdenum nitrogenase consists of two proteins, a Fe-protein (dinitrogenase reductase) and a MoFe-protein (dinitrogenase). These are encoded, respectively, by genes designated nifH and nifDK. However, many diazotrophs also possess genes ( $v n f$ or $a n f$ ) that encode one or more molybdenum-independent nitrogenase (for details, see $[115,116])$. Although the presence of molybdenumindependent nitrogenases has been confirmed in heterocystous cyanobacteria [117-120], there are no reports of such enzymes in non-heterocystous cyanobacteria. Indeed, attempts to demonstrate their existence in Gloeothece sp. ATCC 27152 (PCC 6909) and in Oscillatoria spp. UCSB8 and UCSB25 have proved unsuccessful (T.S. Page and J.R. Gallon, unpublished observations). Whilst production of ethane from acetylene (one of the preliminary diagnostic tests for the presence of molybdenum-independent nitrogenases) was observed in cultures of Microcoleus (Symploca) chthonoplastes incubated in Mo-free medium, no evidence for the existence of vnf or anf genes was obtained (T.S. Page, R.R. Eady, R. Pau and J.R. Gallon, unpublished findings).

Several lines of evidence suggest that molybdenum 
nitrogenase in non-heterocystous cyanobacteria is similar to that in other diazotrophs.

1. Antibodies raised against the Fe-protein and Mo-Fe proteins of nitrogenases from Rhodospirillum rubrum, Azotobacter, Klebsiella pneumoniae, the nonheterocystous cyanobacterium Trichodesmium and the heterocystous cyanobacterium Anabaena variabilis have been shown to cross-react specifically with the corresponding nitrogenase proteins from Plectonema (PCC 6306 and 73110), various Trichodesmium spp., Oscillatoria limosa, Oscillatoria spp. UCSB8 and UCSB25 Aphanothece (Cyanothece) pallida, Cyanothece BH68 and Gloeothece PCC 6909 ([10,51,52,60,107,121-126]; L.A. Sherman, personal communication; our unpublished results).

2. The Fe-protein of $P$. boryanum nitrogenase successfully complements the MoFe-protein of the nitrogenases from a variety of diazotrophs to form catalytically active complexes [127,128]. Similarly, the MoFe-protein of the nitrogenases from $P$. boryanum and Gloeothece have been found to form active complexes with, respectively, the Fe-proteins of nitrogenase from the heterocystous cyanobacterium Anabaena cylindrica [128] and the facultative anaerobe $K$. pneumoniae (P.S. Maryan, unpublished results; quoted in [20]).

3. SDS/PAGE-immunoblot analysis of the Feprotein of nitrogenase from the heterocystous cyanobacteria Anabaena and Nostoc [129-131], and the non-heterocystous cyanobacteria Plectonema boryanum [126] and Trichodesmium [107,122,125,132], shows that these proteins all have a similar apparent $M_{\mathrm{r}}$ of approximately 36000 . There are, however, reports of an $M_{\mathrm{r}}$ as high as 40000 for the Fe-protein in Synechococcus (Cyanothece) RF-1 [133], Trichodesmium [107,134], Oscillatoria limosa [124] and Gloeothece sp. ATCC 27152 [60]. However, measurement is complicated by the fact that, in many cyanobacteria, the Fe-protein of nitrogenase can exist in two distinct forms, of different $M_{\mathrm{r}}$ (see Fig. 1a). Moreover, measurement of $M_{\mathrm{r}}$ by SDS/PAGE has an accuracy no better than $\pm 10 \%$. It is therefore premature to ascribe any structural or physiological significance to the apparent differences in $M_{\mathrm{r}}$ among Fe-proteins from different cyanobacteria.

In a number of diazotrophs, the Fe-protein of nitrogenase undergoes reversible covalent modification by attachment of an ADP-ribose moiety to a specific arginine residue. ADP-ribosylation of the protein is catalysed by dinitrogenase reductase ADP-ribosyl transferase (DRAT), and renders the Fe-protein catalytically inactive. Removal of ADP-ribose is catalysed by dinitrogenase reductase activating glycohydrolase (DRAG) and restores activity. Covalent modification of the Fe-protein has been most extensively studied in photosynthetic bacteria such as Rhodospirillum rubrum and has recently been reviewed by Ludden and Roberts (1989) [135], Nordlund (1991) [136], Roberts and Ludden (1992) [137] and Zhang et al. (1995) [138]. Covalent modification (and associated inactivation) of nitrogenase is stimulated in the presence of ammonium or certain other nitrogen sources, by transfer of cultures to the dark or, to a lesser extent, by exposure to $\mathrm{O}_{2}$ ( $R$. rubrum fixes $\mathrm{N}_{2}$ only under anoxic conditions).

A convenient method for studying covalent modification of the Fe-protein of nitrogenase is SDS/ PAGE. When subjected to SDS/PAGE, ADP-ribosylated Fe-protein migrates more slowly than unmodified Fe-protein, appearing to have a larger $M_{\mathrm{r}}$ (Fig. 1b). In a number of cyanobacteria, including nonheterocystous strains such as Gloeothece ([8]; Fig. 1a), Microcoleus (Symploca) chthonoplastes (D.P. Singh and J.R. Gallon, unpublished observation), Oscillatoria limosa [124], Synechococcus (Cyanothece) RF-1 [133], Synechocystis BO 8402 [34] and Trichodesmium [132,139], the Fe-protein can be resolved into two components by SDS/PAGE. Most detailed studies have been performed with the heterocystous cyanobacterium Anabaena variabilis ATCC 29413 [140-143] and with Gloeothece ATCC 27152 $[8,60,144]$. No incorporation of radioactivity from ${ }^{32} \mathrm{PO}_{4}{ }^{3-}$ into the $\mathrm{Fe}$-protein of nitrogenase and no reaction of this protein with antibodies specific to ADP ribose occurred in either A. variabilis [143] or Gloeothece (J. Cheng, D. Pederson, H. Hilz and J.R. Gallon, unpublished findings). Similarly, attempts to label the Fe-protein from Trichodesmium with ${ }^{32} \mathrm{P}$ proved unsuccessful (unpublished data, cited in [11]). The balance of evidence therefore strongly suggests that the $\mathrm{Fe}$-protein of cyanobacterial nitrogenase is not subjected to ADP ribosylation. On the other hand, although no evidence for the existence of genes encoding DRAT or DRAG was found in $A$. variabilis [143], proteins antigenically similar to both 
DRAT and DRAG have been found in Gloeothece [144]. These proteins were much larger than their counterparts in Rhodospirillum rubrum, but the fact that they were not produced by cultures of Gloeothece growing in medium containing ammonium suggests that they have a role in $\mathrm{N}_{2}$ fixation or related metabolism. The recent finding that glutamine synthetase, a key enzyme in the assimilation of nitrogen, is subject to ADP ribosylation in the non-diazotrophic unicellular cyanobacterium Synechocystis sp. PCC 6803 [145], raises the possibility that the DRAT- and DRAG-like proteins in Gloeothece may act on this enzyme rather than the Fe-protein of nitrogenase. Unfortunately however, we have so far been unable to detect any incorporation of ${ }^{32} \mathrm{PO}_{4}{ }^{3-}$ into immunologically identifiable glutamine synthetase during SDS/PAGE of extracts of Gloeothece, nor have we observed any immunological reaction between this protein and antibodies to ADPribose (J. Cheng, H. Hilz and J.R. Gallon, unpublished results).

In dense suspensions of Synechocystis BO 8402, which fixes $\mathrm{N}_{2}$ only when incubated under anoxic or micro-oxic conditions, the presumed modified (higher $M_{\mathrm{r}}$ ) form of the $\mathrm{Fe}$-protein is not present in the absence of $\mathrm{O}_{2}$, but appears when $\mathrm{O}_{2}$ is introduced into the atmosphere above cultures [34]. Under these conditions, nitrogenase activity is inhibited, so 'modified' Fe-protein may be catalytically inactive. On return to anoxic incubation conditions, nitrogenase activity recovers, accompanied by the reappearance of the unmodified form of the Feprotein. Though capable of aerobic $\mathrm{N}_{2}$ fixation, Gloeothece and Trichodesmium behave similarly. Both forms of the Fe-protein can be seen in natural populations of Trichodesmium and in aerobically grown cultures of Gloeothece. However, exposure to $\mathrm{O}_{2}$ at concentrations greater than those in air inhibited $\mathrm{N}_{2}$ fixation and markedly stimulated the appearance of the 'modified' form of the Fe-protein in both Gloeothece [8,60] and Trichodesmium $[11,132]$. On the other hand, nitrogenase activity can be detected in cultures of Gloeothece grown in the absence of atmospheric $\mathrm{O}_{2}$ even when they apparently contain only 'modified' Fe-protein, implying that this form retains catalytic activity under these conditions [60]. In Gloeothece therefore, modification of the Fe-protein may render it extremely sensitive to inactivation by $\mathrm{O}_{2}$, rather than catalytically inactive per se.

Plectonema boryanum differs from these other nonheterocystous cyanobacteria in that no modification of the Fe-protein of its nitrogenase could be observed, even following exposure to $\mathrm{O}_{2}$. Such treatment simply resulted in the complete disappearance of nitrogenase from the cells [126].

There is no evidence that the nif genes in nonheterocystous cyanobacteria differ significantly from those in other diazotrophs. DNA gene probes from Anabaena PCC 7120, containing the nitrogenase structural genes nif $H, D$, and $K$ hybridize specifically with DNA from Cyanothece PCC 7424 [24], Gloeothece [146,147], Lyngbya [147], Plectonema [24,147150], Pseudanabaena [24,151,152], Oscillatoria [151], Synechococcus [24] and Trichodesmium [153]. Similarly nif gene probes from $K$. pneumoniae hybridize to genomic DNA from Pseudanabaena PCC 7409 [152]. In addition, nif probes from Anabaena 7120 hybridize with, presumed, nitrogenase-specific mRNA in Synechococcus RF-1 [154,155]. The nifH genes from Trichodesmium thiebautii [156] and Trichodesmium sp. strain NIBB 1067 [125] have been cloned and partially sequenced. A comparison of the nucleotide sequence, and the deduced amino acid sequence, showed $98 \%$ similarity between the two Trichodesmium spp. and $80-87 \%$ similarity with heterocystous strains Anabaena 7120 and Anabaena flos-aquae. These findings have been extended with the first report of the complete sequence of nifH from natural populations of $T$. thiebautii [157], from which a strong similarity to 23 known nifH sequences was confirmed. Partial sequences are also available for nifH from Gloeothece sp. CCAP 1430/3 (= PCC 6909), Plectonema boryanum UTEX 594 (= PCC 73110) and Lyngbya lagerheimii UTEX 1930 [147]. The degree of similarity among nifH sequences from the various non-heterocystous cyanobacteria was $70-81 \%$, rather lower than that among the heterocystous Anabaena and Nostoc strains tested (84-92\%). However, the fragments cross-hybridized with each other to a varying extent. The nucleotide and encoded amino acid sequences for nifU, nifH and nifD genes in Plectonema boryanum show $70 \%$, $84 \%$ and $76 \%$ homology with Anabaena 7120 nif $U, H$ and $D$ genes, respectively [158]. Furthermore, upstream from both nifH and nifD (which has been 
partially sequenced) in $T$. thiebautii were sequences resembling consensus nif-like promoters from other diazotrophs [157]. These findings are consistent with the view that among all diazotrophs, nitrogenase and the nif structural genes are highly conserved.

The arrangement of nif structural genes has been studied in the unicellular cyanobacteria Gloeothece PCC 6909, Synechococcus strains PCC 7335 and 7425 and Cyanothece PCC 7424, as well as in the filamentous forms Pseudanabaena strains PCC 7403 and 7409, Oscillatoria tenuis UTEX 1566, Trichodesmium strain NIBB 1067 and $P$. boryanum strains PCC 6306, 73110 and IAM-M 101. In all $\mathrm{N}_{2}$-fixing non-heterocystous cyanobacteria, whether or not they can fix $\mathrm{N}_{2}$ under oxic conditions, the nif structural genes are contiguous and arranged in the order nifHDK [24,146,148-153,157,158]. Such contiguous arrangement of nif structural genes resembles that in bacteria and in heterocysts of cyanobacteria but contrasts with the situation in vegetative cells of the heterocystous cyanobacterium Anabaena PCC 7120, in which nifK is separated by $11 \mathrm{~kb}$ from nifDH. In Anabaena 7120 and certain other heterocystous cyanobacteria, excision of this element occurs during heterocyst differentiation but, so far, there is no evidence for any similar genomic rearrangement in non-heterocystous cyanobacteria $[74,159$, 160].

Genes resembling nifH and nifDK (sequence similarity $34 \%$ and $15-20 \%$, respectively) have been implicated in the later stages of chlorophyll biosynthesis in Plectonema boryanum [158,161,162]. The nif $H$-like gene $(f r x C)$ encodes a protein that is involved in the light-independent reduction of protochlorophyllide to chlorophyllide, a process that may also involve the product of the nifDK-like gene (ORF 467). It is possible that the FrxC protein may donate electrons to the protein encoded by ORF 467, which in turn reduces protochlorophyllide to chlorophyllide [162]. If so, this resembles the catalytic function of the $\mathrm{Fe}$ - and $\mathrm{MoFe}$-proteins of nitrogenase: the $\mathrm{Fe}$-protein functions as an electron donor to the $\mathrm{MoFe}$-protein which then catalyses $\mathrm{N}_{2}$ reduction (see, for example, [163-167]; Fig. 3). The two systems may therefore resemble each other functionally as well as structurally, and may share a common ancestry.

\subsection{Derepression of nitrogenase}

In diazotrophs, nitrogenase synthesis is derepressed under conditions of nitrogen limitation. $\mathrm{N}_{2}$ is not an inducer of nitrogenase synthesis, though sustained derepression of nitrogenase depends on active $\mathrm{N}_{2}$ fixation in order to maintain general nitrogen status and thereby allow protein synthesis to continue [168]. In cyanobacteria that can fix $\mathrm{N}_{2}$ aerobically, nitrogenase synthesis occurs in the presence of air. In contrast, those cyanobacteria that fix $\mathrm{N}_{2}$ only under anoxic or micro-oxic conditions require both nitrogen stress and the presence of no more than trace amounts of $\mathrm{O}_{2}$ for nitrogenase derepression and activity $[3,18,35,126,127,169-171]$. Apparently, these strains possess inadequate mechanisms to remove atmospheric and endogenously evolved $\mathrm{O}_{2}$. Complete absence of $\mathrm{O}_{2}$ is generally not required but an equilibrium between ingress of atmospheric $\mathrm{O}_{2}$, photosynthetic $\mathrm{O}_{2}$ evolution and respiratory $\mathrm{O}_{2}$ consumption is necessary. Among these cyanobacteria, detailed studies have largely been restricted to Plectonema boryanum in which nitrogenase synthesis has been derepressed under photoautotrophic as well as under photoheterotrophic conditions $[3,172,173]$. In this cyanobacterium nitrogenase synthesis can be derepressed by sparging with $\mathrm{Ar}, \mathrm{Ar} / \mathrm{CO}_{2}$, or $\mathrm{N}_{2} /$ $\mathrm{CO}_{2}$ at the low light intensity of $500 \mathrm{~lx}$ (which, for fluorescent lights, corresponds approximately to 6 $\mu \mathrm{mol}$ photons $\mathrm{m}^{-2} \mathrm{~s}^{-1}$ over the range 400-700 $\mathrm{nm})$. However, at higher light intensities addition of DCMU $(5 \mu \mathrm{M})$ or sodium sulphide $(2 \mathrm{mM})$ is also necessary in order to inhibit photosynthetic generation of $\mathrm{O}_{2}$. The duration of exposure to anoxic or micro-oxic conditions necessary for nitrogenase derepression depends on the nitrogen status of the cells. When nitrate-grown cultures of $P$. boryanum are transferred to nitrogen-free medium under anoxic or micro-oxic conditions, nitrogenase derepression takes 24-30 h [3,126]. However, $24 \mathrm{~h}$ aerobic incubation in nitrogen-free medium, prior to transfer to anoxic or micro-oxic conditions results in derepression of nitrogenase within $2-3$ h $[18,126,127,169,170]$. Sparging with $\mathrm{Ar}, \mathrm{Ar} / \mathrm{CO}_{2}$, or $\mathrm{N}_{2} / \mathrm{CO}_{2}$ need not be continuous. Nitrogenase derepression has also been reported in this cyanobacterium under conditions of periodic sparging $[3,126]$.

The molecular mechanism by which ammonium 
represses the synthesis of nitrogenase (and other proteins related to the use of nitrogen sources other than ammonium) is well documented in enteric bacteria (see, for example, $[8,174]$ ). The $\mathrm{P}_{\mathrm{II}}$ protein responds to intracellular nitrogen status and interacts with the two-component $\mathrm{NtrB} / \mathrm{NtrC}$ system in such a way that the protein $\mathrm{NtrC}$ becomes phosphorylated under conditions of nitrogen limitation. Phosphorylated $\mathrm{NtrC}$ is required for transcription of, among others, the nif genes. Transcription also requires a protein RpoN (NtrA) that functions as a sigma factor to RNA polymerase and allows it to recognise Ntr-regulated promoters. Repression of nitrogenase synthesis by ammonium can be explained as follows: in the presence of ammonium, cells become nitrogenreplete, $\mathrm{NtrC}$ is not phosphorylated so the nif genes are not, therefore, expressed. Other sources of inorganic nitrogen such as nitrate, which is reduced to ammonium by the action of nitrate and nitrite reductases, similarly repress nitrogenase synthesis.

A $\mathrm{P}_{\mathrm{II}}$ kinase $/ \mathrm{P}_{\mathrm{II}}$ protein pair has been found in the non-diazotrophic unicellular cyanobacterium Synechococcus PCC 7942 [175], in which it functions as a signal sensor/transmitter of the illumination regime and intracellular nitrogen status [176]. However, despite intensive study, no genes corresponding to the $n t r$ genes have been found in cyanobacteria. On the other hand, a novel regulatory gene, $n t c A$ (previously known as $b i f A$ ), has been identified in both non-heterocystous and heterocystous cyanobacteria [177182]. The product of this gene, NtcA, is a DNAbinding protein similar to the cAMP-binding catabolite gene activator protein (CAP: also known as the cyclic AMP receptor protein, Crp) that acts as a positive activator of the E. coli lac operon (see [183] and references therein). NtcA binds to a palindromic DNA sequence $\mathrm{GTAN}_{8}$ TAC, situated at varying distances upstream from the transcription start site in the promoters of NtcA-regulated genes [182]. Strains of the heterocystous cyanobacterium Anabaena PCC 7120 carrying mutations in ntcA were unable to use either nitrate or $\mathrm{N}_{2}$ as a nitrogen source for growth $[184,185]$, hence NtcA may regulate nitrogenase synthesis in cyanobacteria. Several NtcA-regulated genes in cyanobacteria have been implicated in $\mathrm{N}_{2}$ fixation and heterocyst differentiation. These include at least some nif genes, $g \ln A$ (encoding glutamine synthetase), xis $A$ (which encodes an excisase that is involved in the gene rearrangements that accompany heterocyst differentiation) and $g l b N$ (which encodes cyanoglobin: M. Potts, personal communication; also see Section 6.4, below). However, NtcA may also regulate genes that respond in a more general way to the presence of nitrogenous compounds. Such genes include $r b c L$ (encoding the $\mathrm{CO}_{2}$-fixing enzyme, Rubisco) and the gor genes (which encode glutathione reductase, an enzyme that may have a role in protecting nitrogenase against oxidative stress: [182]; see Section 6.4. However, exactly how NtcA responds to intracellular nitrogen status, and whether $\mathrm{P}_{\mathrm{II}}$ is involved with $\mathrm{NtcA}$, is not yet known.

\subsection{Subcellular location}

Following the original proposal that the heterocyst was the site of aerobic $\mathrm{N}_{2}$ fixation in heterocystous cyanobacteria [186], there was some argument about whether vegetative cells also contained active nitrogenase under anoxic or micro-oxic conditions (for a review, see [187]). For example, the ability of certain non-heterocystous, filamentous cyanobacteria to fix $\mathrm{N}_{2}$ under these conditions demonstrated that possession of heterocysts was not an essential prerequisite for $\mathrm{N}_{2}$ fixation. However, the immunocytochemical demonstration that nitrogenase was confined to heterocysts of Anabaena cylindrica [188] and other freeliving and symbiotic cyanobacteria ([189]; see Plate 4d) incubated under either oxic or anoxic conditions, led to the general belief that the heterocyst was always the sole site of $\mathrm{N}_{2}$ fixation. Studies on the expression of nifHDK in individual cells of Anabaena 7120 under both oxic and anoxic conditions [190] supported this view. However, the recent discovery that Anabaena variabilis possesses two molybdenum nitrogenases, one (Nif-1) that functions either under oxic or anoxic conditions but is confined to heterocysts and one (Nif-2) that functions only under anoxic conditions but is present in both vegetative cells and heterocysts [191,192], has reopened the whole debate. The situation varies among different strains of heterocystous cyanobacteria: Anabaena 7120, for example, possesses a heterocyst-specific Nif-1 system but no functional vegetative cell Nif-2 nitrogenase [192]. Nevertheless, in all heterocystous cyanobacteria incubated aerobically, nitrogenase activity is ap- 
parently confined to heterocysts while oxygenic photosynthesis occurs in the undifferentiated vegetative cells $[7,8,188,189,193]$.

In contrast, non-heterocystous cyanobacteria express nitrogenase in what appear to be $\mathrm{O}_{2}$-evolving vegetative cells. No obviously differentiated cells have been reported in either unicellular or filamentous forms [20]. Meeks et al. (1978) proposed that nitrogenase may be located in only certain cells within individual filaments of cultures of $P$. boryanum grown under anoxic conditions or within the characteristically ensheathed aggregates of aerobically grown Gloeothece [194]. However, subsequent fluorescence studies by Giani and Krumbein (1986) failed to identify any unusual cells within $\mathrm{N}_{2}$-fixing filaments of $P$. boryanum PCC 73110 [170]: the same is true of Gloeothece [187]. On the other hand, Giani and Krumbein (1986) suggested that nitrogenase may be subjected to intracellular separation from the photosynthetic apparatus in P. boryanum [170]. That this may also be the case in Gloeothece is consistent with, though not proved by, the findings that photosynthesis and $\mathrm{N}_{2}$ fixation are not closely linked in this organism [187]. For example, atmospheric $\mathrm{O}_{2}$ is needed to sustain maximum rates of nitrogenase activity even in illuminated cultures of Gloeothece [195], probably because, except at high light intensities, ATP for $\mathrm{N}_{2}$ fixation is generated by respiratory rather than photosynthetic activity ([196]; see Section 6.3.

Immunochemical studies have recently been conducted on Plectonema boryanum PCC 73110 [126], Oscillatoria limosa ([124]; Plate 4b), Lyngbya aestuarii (which may be the same organism as $O$. limo$s a$ : see Section 6.2.2 [37] and Gloeothece PCC 6909 (Plate 4a) for localization of the Fe-protein of nitrogenase and on P. boryanum PCC 6306 [123] for localization of the Mo-Fe protein. These studies have shown that in Plectonema, Oscillatoria, Lyngbya and Gloeothece, nitrogenase is expressed in all the cells and within each cell the antigen is distributed uniformly throughout the cell without any preferential association with any subcellular structures. Although these findings tell us nothing about the cellular distribution of nitrogenase activity, they nevertheless argue against the possibility of intercellular or intracellular compartmentation of nitrogenase in these cyanobacteria.
The situation in the marine non-heterocystous cyanobacterium Trichodesmium is more complex (Plate 4c). Trichodesmium spp. often grow in distinct colonial aggregates and occur in highly oxygenated waters. Early work suggested that $\mathrm{N}_{2}$ fixation might be confined to the central regions of these colonies [197]. Individual filaments (trichomes) passing through this region were claimed to possess 10-20 lightly pigmented cells that did not fix $\mathrm{CO}_{2}$ and, like heterocysts, contained a reducing environment [198]. It was therefore proposed that the central region of colonies of Trichodesmium might be the preferred site of aerobic $\mathrm{N}_{2}$ fixation. In this way, Trichodesmium, like heterocystous cyanobacteria, might effect a spatial separation between the $\mathrm{O}_{2}$-sensitive process of $\mathrm{N}_{2}$ fixation and oxygenic photosynthesis, though without any obvious cellular differentiation. However, a more detailed reinvestigation of this possibility by Carpenter et al. (1990) showed that the central region of colonies of $T$. thiebautii might well be photosynthetically active [199]. Furthermore, Paerl et al. (1989) found that almost all cells in colonies of Trichodesmium contained immunologically identifiable nitrogenase [122]. Even though subsequent detailed immunological studies have clearly demonstrated that relatively few individual cells in colonies of Trichodesmium spp. contained nitrogenase, those that did were always randomly distributed within the aggregate of trichomes rather than being confined to a specific central region [107]. A recent survey of a number of colonial Trichodesmium species has shown that, on average, only $14 \%$ of individual cells in a colony contained nitrogenase, and this was irrespective of sampling location, season or time of day [52]. This means that, in contrast to all other non-heterocystous cyanobacteria tested, a minority of cells in Trichodesmium is engaged in $\mathrm{N}_{2}$ fixation at any one time. It also suggests that differential gene expression occurs in Trichodesmium. However, it remains unknown whether nitrogenase is present in all the cells of a few trichomes or in a few cells of rather more, and perhaps all, individual trichomes in a colony of Trichodesmium. The latter hypothesis is, however, gaining support because both natural populations of $T$. contortum and the recently established laboratory culture of Trichodesmium [61] possess nitrogenase-containing and nitrogenase-free cells within individual trichomes ([51,52]; C. Fredriksson, 
H.W. Paerl and B. Bergman, unpublished data). The nitrogenase-containing cells may correspond to a subtly differentiated region of 7-15 rather short cells that appear brighter in the light microscope but which otherwise are structurally indistinguishable from other cells in the trichome [51]. For instance, there is no thickening of the cell walls as is the case with the clearly differentiated heterocysts of heterocystous cyanobacteria.

Whatever the distribution of nitrogenase among individual cells in a colony of Trichodesmium, there is an even distribution of the Fe-protein of nitrogenase within the nitrogenase-containing cells themselves ([10,52]; Plate 4c).

The brightness of certain regions within trichomes of Trichodesmium was not due to loss of pigments, as suggested previously. Cells that contained nitrogenase also contained the accessory photosynthetic pigments phycocyanin and phycoerythrin, along with the photosynthetic $\mathrm{CO}_{2}$-fixing enzyme, Rubisco. These cells therefore appear to have the capacity for both photosynthesis and $\mathrm{N}_{2}$ fixation [200]. This does not, of course, prove that photosynthesis and $\mathrm{N}_{2}$ fixation are both active within these cells, and Paerl et al. (1995) have shown that certain regions within trichomes of both natural and laboratory populations of Trichodesmium showed no ability to fix $\mathrm{CO}_{2}$ [201]. It remains possible therefore that the limited number of cells that contain nitrogenase within a colony of Trichodesmium are also photosynthetically inactive. If so, this would contrast markedly with the situation in Plectonema, Oscillatoria, Lyngbya, and Gloeothece, but would resemble that in heterocystous cyanobacteria.

\subsection{Intracellular concentrations of nitrogenase}

A comparison of the intracellular concentration of the Fe-protein of nitrogenase in heterocysts of Anabaena cylindrica with that in vegetative cells of $\mathrm{Os}^{-}$ cillatoria limosa, based on measurements of the density of immunogold labelling per unit cell area under conditions where only the presence of antigen limited the degree of labelling, suggested that there were similar levels of nitrogenase antigen in both cell types [124]. Similar intensities of labelling have also been found in Plectonema boryanum [126], Trichodesmium [107,122] and Gloeothece PCC 6909 (Plate 4a). Ex- cept in Trichodesmium, nitrogenase was present in all of the cells of non-heterocystous cyanobacteria but only in the heterocysts of heterocystous cyanobacteria. Since heterocysts form approximately $5-10 \%$ of the total cell population, it appears that a culture of a non-heterocystous cyanobacterium contains 10-20 times the amount of nitrogenase present in an equivalent culture of a heterocystous cyanobacterium. If nitrogenase-containing cells represent $14 \%$ of the total population of cells in cultures of Trichodesmium [52], then other non-heterocystous cyanobacteria would contain about six times the amount of nitrogenase of an equivalent culture of this organism. However, the maximum rates of $\mathrm{N}_{2}$ fixation reported in the literature for non-heterocystous cyanobacteria are either identical to, or only marginally higher, than the rates reported for heterocystous cyanobacteria (see Table 3). Antibodies raised against nitrogenase do not differentiate between active and inactive enzyme, so it is possible that most of the nitrogenase detected by immunolabelling in non-heterocystous cyanobacteria is inactive. However, whether or not this is actually the case, it seems that heterocysts, and the nitrogenase-containing cells of Trichodesmium, are much more efficient than the vegetative cells of non-heterocystous cyanobacteria in carrying out $\mathrm{N}_{2}$ fixation.

Why this should be is not clear, but it is likely that heterocysts and, possibly, the $\mathrm{N}_{2}$-fixing cells of Trichodesmium, provide a better $\mathrm{O}_{2}$-depleted environment for nitrogenase than the vegetative cells of most non-heterocystous cyanobacteria. Consistent with this, many non-heterocystous cyanobacteria cannot sustain an active nitrogenase under the double stress of oxygenic photosynthesis and aerobiosis, so they fix $\mathrm{N}_{2}$ only when incubated under micro-oxic or anoxic conditions, with photosynthetic $\mathrm{O}_{2}$ production inhibited by DCMU. Even in those strains that can fix $\mathrm{N}_{2}$ aerobically, inhibition of photosynthesis by DCMU can often lead to a transient stimulation of nitrogenase activity. This has been observed in Synechococcus (Cyanothece) RF-1 [202], Trichodesmium [12], Oscillatoria limosa [42], Oscillatoria UCSB8 [46] and UCSB25 (Gallon, unpublished), but not in Synechococcus (Cyanothece) BG 43522 [26]. The situation in Gloeothece is less clear, there are some reports that $\mathrm{N}_{2}$ fixation is not stimulated by addition of DCMU $[12,187,203]$ and others where 
a clear stimulation was seen [204]. However, the extent to which DCMU might stimulate $\mathrm{N}_{2}$ fixation would depend upon the extent to which photosynthetic $\mathrm{O}_{2}$ evolution was coexisting with $\mathrm{N}_{2}$ fixation in individual cells of Gloeothece. This can vary (see Section 6.2.1.

Another factor that might explain the apparently poor efficiency of $\mathrm{N}_{2}$ fixation in vegetative cells of non-heterocystous cyanobacteria relative to that in heterocysts might be competition for ATP and reductant. Heterocysts do not grow or divide and their metabolism is primarily directed to supporting $\mathrm{N}_{2}$ fixation. Their metabolism depends upon the supply of carbohydrate from the two adjacent vegetative cells [205] but the ATP and reductant generated by catabolism of this carbohydrate can be largely directed towards $\mathrm{N}_{2}$ fixation. A similar argument could be made for the $\mathrm{N}_{2}$-fixing cells of Trichodesmium, which may not photosynthesize [68], even though they contain phycobiliproteins and Rubisco $[51,200]$. In contrast, as well as supporting $\mathrm{N}_{2}$ fixation, the vegetative cells of non-heterocystous cyanobacteria have to generate photosynthate (by $\mathrm{CO}_{2}$ fixation, a process that also requires ATP and reductant), to scavenge additional $\mathrm{O}_{2}$ generated during photosynthesis (which can consume reductant) and to provide energy for cell growth and multiplication. It would be of interest, though difficult, to make a comparative study of the abilities of heterocysts, $\mathrm{N}_{2}$ fixing cells of Trichodesmium and other $\mathrm{N}_{2}$-fixing non-heterocystous cyanobacteria to supply reductant and ATP for $\mathrm{N}_{2}$ fixation and also to scavenge $\mathrm{O}_{2}$.

\section{Nitrogenase and metabolism}

\subsection{Adaptation to diazotrophy}

When given $\mathrm{N}_{2}$ as sole nitrogen source, heterocystous cyanobacteria undergo profound morphological and physiological changes, culminating in the development of heterocysts $[160,206]$. In addition to the appearance of nitrogenase activity, development of heterocysts from vegetative cells results in increased intracellular concentrations of glutamine synthetase and increased respiratory activity, but loss of Rubisco, nitrate reductase and photosynthetic $\mathrm{O}_{2}$ evolu- tion [131,205,207-209]. Often, but not always, the accessory photosynthetic phycobiliprotein pigments are lost during heterocyst differentiation. An equivalent study of the metabolic changes that occur in non-heterocystous cyanobacteria during transfer from growth on, say, ammonium to growth on $\mathrm{N}_{2}$ is lacking. However, there are a number of reports that one or more of the metabolic changes observed during heterocyst differentiation also occur in nonheterocystous cyanobacteria when they adapt to growth under $\mathrm{N}_{2}$-fixing conditions. These include a decline in photosynthetic activity $\left(\mathrm{O}_{2}\right.$ evolution; $\mathrm{CO}_{2}$ fixation), an increase in respiratory activity $\left(\mathrm{O}_{2}\right.$ uptake; amounts and activity of cytochrome oxidase) and a disappearance of nitrate reductase [20,46, 68,126,209-212]. An increase in intracellular glutamine synthetase has also been noted in Plectonema boryanum [126] and in the nitrogenase-containing cells of Trichodesmium [213], but this increase was much smaller than that observed in heterocystous cyanobacteria during heterocyst differentiation. Unlike heterocysts, the $\mathrm{N}_{2}$-fixing vegetative cells of nonheterocystous cyanobacteria retain Rubisco and phycobiliproteins.

It should be emphasized that the metabolic changes that occur during heterocyst differentiation are permanent, whilst those noted during development of $\mathrm{N}_{2}$ fixation in non-heterocystous cyanobacteria can be reversed following resupply of a nitrogen source such as ammonium. Heterocysts are terminally differentiated cells, specialized in $\mathrm{N}_{2}$ fixation but lacking the ability either to grow or to divide. They do not dedifferentiate into vegetative cells following addition of ammonium, though further differentiation of heterocysts is blocked by such treatment and the proportion of preexisting heterocysts declines as a result of continued division of vegetative cells. In contrast, $\mathrm{N}_{2}$-fixing vegetative cells of nonheterocystous cyanobacteria continue to grow and divide and rapidly revert to non-diazotrophic metabolism following addition of ammonium. Nitrogenase-containing cells of Trichodesmium may divide (C. Fredriksson and B. Bergman, unpublished), which indicates that these cells are not terminally differentiated. Indeed, it is possible that these cells may undergo a natural regression during which they lose the ability to fix $\mathrm{N}_{2}$ (see, for example, [11]), implying that expression of the nif genes may 
be regulated by the cell cycle. Such behaviour would explain the observation that the proportion of nitrogenase-containing cells is remarkably constant (less than $20 \%$ ) in all colonies and free-living trichomes of Trichodesmium examined.

Nitrate has a similar effect to ammonium in repressing nitrogenase synthesis in cyanobacteria (see, for example, [180]). However, it is often more difficult completely to eliminate nitrogenase activity in cultures growing on nitrate as nitrogen source than in cultures growing on ammonium [187]. Nevertheless, most studies compare cultures grown in nitrogen-free medium ( $\mathrm{N}_{2}$-fixing) with cultures grown in medium containing nitrate. That the latter are not fixing $\mathrm{N}_{2}$ cannot be taken for granted and should always be carefully checked. It is usually much safer to compare cultures grown in the absence and presence of ammonium. In a detailed study of the interactions between different nitrogen sources in Gloeothece, Cheng et al. (1995) showed that the ability to assimilate nitrate was present in $\mathrm{N}_{2}$-fixing cultures but not in ammonium-grown cultures [214]. In this respect, Gloeothece differs from other $\mathrm{N}_{2}$-fixing cyanobacteria [180], including Plectonema boryanum [126], in that the presence of nitrate is not strictly required in order to induce its own assimilation system.

\subsection{Patterns of diazotrophic growth}

\subsubsection{Laboratory cultures}

In non-heterocystous cyanobacteria, as in heterocystous forms, ammonium derived from $\mathrm{N}_{2}$ fixation is assimilated by the glutamine synthetase-glutamate synthase (GOGAT) pathway [193,194,215]. A number of non-heterocystous cyanobacteria that can fix $\mathrm{N}_{2}$ aerobically can be grown in the laboratory with $\mathrm{N}_{2}$ as the sole nitrogen source. These strains can be cultivated either under continuous illumination or under a regime of alternating light and darkness (see, for example, $[6,8,20]$ ). In many cases, $\mathrm{N}_{2}$ fixation and photosynthesis in these strains show opposing cyclic fluctuations, but growth seems to be continuous except in Synechococcus (Cyanothece) strains BG 43511 and 43522. In these cyanobacteria cell division exhibits a cyclic pattern, coinciding with the peak of oxygenic photosynthesis $[23,26]$. On the other hand, fluctuations in $\mathrm{N}_{2}$ fixation and photo- synthesis are also seen in non-growing cultures of Synechococcus (Cyanothece) BG 43511 [216].

Although many non-heterocystous cyanobacteria have been shown to fix $\mathrm{N}_{2}$ under micro-oxic or anoxic conditions, it is not certain how many of them can actually grow diazotrophically. Laboratory studies have been largely restricted to a single organism, Plectonema boryanum. Rogerson (1980) showed that this cyanobacterium could grow photoheterotrophically on $\mathrm{N}_{2}$ when illuminated continuously under anoxic conditions in the presence of exogenously supplied fructose and a constant concentration of sulphide (which inhibited photosynthetic $\mathrm{O}_{2}$ evolution but acted as an electron donor to anoxygenic photosynthesis) [172]. Subsequently, Pearson and Howsley (1980) reported concomitant photoautotrophic growth and $\mathrm{N}_{2}$ fixation in cultures of the same strain grown under micro-oxic conditions [217]. Giani and Krumbein (1986) [170] could not reproduce these results under the high light intensities used by Pearson and Howsley (1980) [217] but found that, when continuously sparged with $\mathrm{O}_{2}$-depleted air at light intensities below 500 lx (approximately $6 \mu \mathrm{mol}$ photons $\mathrm{m}^{-2} \mathrm{~s}^{-1}$ ), P. boryanum grew exponentially under photoautotrophic conditions using $\mathrm{N}_{2}$ as sole nitrogen source. Furthermore, growth rates were comparable to those in cultures using nitrate as nitrogen source. Moreover, when $P$. boryanum was grown in nitrogen-free medium and sparged with $\mathrm{N}_{2} / \mathrm{CO}_{2}(95: 5 \mathrm{v} / \mathrm{v})$ for $15 \mathrm{~min}$ at $6 \mathrm{~h}$ intervals rather than continuously, it exhibited a cyclic growth pattern rather like that of Synechococcus BG 43511 [126,218,219]. Such cultures showed periodic peaks of nitrogenase activity which coincided with troughs in the rate of photosynthetic $\mathrm{O}_{2}$ evolution [126,218]. Cell growth, measured as an increase in the protein content of the culture, followed each peak of $\mathrm{N}_{2}$ fixation. This pattern may have its origin in periodic anoxic conditions created by fluctuations in oxygenic photosynthesis, and it has been shown that a stimulation of Photosystem I coupled with a corresponding inhibition of the $\mathrm{O}_{2}$-evolving Photosystem II accompanies rapid diazotrophic growth of $P$. boryanum [220]. Significantly, these findings suggest that $P$. boryanum could grow photoautotrophically using $\mathrm{N}_{2}$ as a sole nitrogen source in appropriate micro-oxic natural habitats.

When growing under alternating light and dark- 
ness, cultures of most non-heterocystous cyanobacteria that can fix $\mathrm{N}_{2}$ aerobically do so during the dark phase, thereby achieving a temporal separation of $\mathrm{N}_{2}$ fixation and oxygenic photosynthesis (see [8,31,221]; Fig. 2a). The molecular mechanism underpinning this behaviour may, however, vary from organism to organism. In Oscillatoria limosa, for example, the disappearance of nitrogenase activity during the light phase coincides with the appearance of the modified form of the Fe-protein of nitrogenase [222]. Nitrogenase is present in the cells throughout a $24 \mathrm{~h}$ cycle of alternating light and darkness, though induction of nitrogenase activity at the end of each light period depends on protein synthesis [223]. In contrast, in Gloeothece, nitrogenase undergoes a diurnal cycle of synthesis and degradation [60], with modification of the $\mathrm{Fe}$-protein relegated to a secondary role. Nitrogenase disappears from cells of Gloeothece at the end of each dark phase and is resynthesized at the end of each light phase [60,210]. Synthesis of nitrogenase is regulated by the availability of ATP, reductant and carbon skeletons, which arise from the breakdown of endogenous glucan reserves that accumulate during each light period $[8,210]$. Breakdown of the enzyme is catalyzed by the action of a proteolytic system that appears to be highly specific for Gloeothece nitrogenase [224]. Synechococcus (Cyanothece) RF-1 shows a similar pattern of nitrogenase synthesis and degradation [133]. In this cyanobacterium, 'modified' Fe-protein may be targeted for degradation [133], but there is no evidence that this is so in Gloeothece, in which both forms of the Fe-protein disappear together [60]. However, since degradation is very rapid, especially once cells return to the light phase, it is not possible to determine whether disappearance of 'unmodified' protein is due to direct degradation or to modification followed by degradation of 'modified' Fe-protein. On the other hand, 'unmodified' Fe-protein $\left(M_{\mathrm{r}}=38500\right.$; Fig. 1a) is susceptible to proteolytic degradation by extracts of Gloeothece [224], whilst both 'modified' and 'unmodified' Fe-protein were similarly degraded in extracts of heterocysts of Anabaena variabilis [225].

In Oscillatoria strain UCSB8, the pattern of nitrogenase activity seen during photoautotrophic growth under alternating $12 \mathrm{~h}$ light and $12 \mathrm{~h}$ darkness is also seen in cultures growing photoheterotrophically with glucose as carbon source [46]. Under these conditions, it is extremely unlikely that the pattern of $\mathrm{N}_{2}$ fixation is imposed by fluctuations in available carbon, as occurs in Gloeothece. Fluctuations in intracellular nitrogen reserves rather than glucan may therefore regulate nitrogenase activity and, perhaps, synthesis in Oscillatoria UCSB8 [46]. In Synechococcus (Cyanothece) strain BG 43511, the status of both intracellular carbon and intracellular nitrogen reserves may regulate cell cycle-linked and cell cycle-independent fluctuations in $\mathrm{N}_{2}$ fixation [216].

Not all non-heterocystous cyanobacteria fix $\mathrm{N}_{2}$ exclusively during the dark phase of a cycle of alternating light and darkness. Gloeothece, for example, grown under anoxic conditions $[6,20,60]$ or with a continuous supply of sulphate [226,227] fixes $\mathrm{N}_{2}$ during the light phase of such a cycle. Synechococcus (Cyanothece) sp. BG 43511 behaves similarly [228]. Clearly, the 'normal' (in the sense that it also occurs in natural populations [92]) pattern of $\mathrm{N}_{2}$ fixation in cultures of Gloeothece grown under alternating light and darkness can be extensively modified by the external environment. However, both natural populations and laboratory cultures of the marine aerotolerant diazotroph, Trichodesmium fix $\mathrm{N}_{2}$ during the light phase of a cycle of alternating light and darkness (for details, see [11,12]; Fig. 2b). Two other marine, aerotolerant diazotrophs may behave similarly. Laboratory cultures of the unicellular cyanobacterium Synechococcus (Cyanothece) strain SF1 [27] and natural populations of the filamentous organism Lyngbya majuscula [36], were unable to fix $\mathrm{N}_{2}$ in the dark.

In Trichodesmium, nitrogenase is confined to a few cells that probably do not photosynthesize and may not evolve $\mathrm{O}_{2}$. This may be significant in explaining the lack of temporal separation between photosynthetic $\mathrm{O}_{2}$ evolution and $\mathrm{N}_{2}$ fixation in this organism, since heterocystous cyanobacteria, which also perform a spatial separation of $\mathrm{N}_{2}$ fixation and oxygenic photosynthesis, fix $\mathrm{N}_{2}$ exclusively during the light phase of a cycle of alternating light and darkness [44]. In at least some laboratory cultures of Trichodesmium, immunologically detectable Fe-protein persists throughout an alternating cycle of light and darkness, with 'unmodified' (presumed active) Fe-protein present only during the light phase 
[139]. This is the exact opposite of the behaviour seen in Oscillatoria limosa [222].

Despite the apparent temporal separation between oxygenic photosynthesis and $\mathrm{N}_{2}$ fixation observed in cultures of the microaerophilic cyanobacterium Plectonema boryanum, there have been no studies on cultures growing under alternating light and darkness. Such cultures cannot grow aerobically on $\mathrm{N}_{2}$ as a nitrogen source ([40]; J.R. Gallon, unpublished observations) and the report that $\mathrm{N}_{2}$ fixation in $P$. boryanum requires light $[219,220]$ implies that, when grown in the absence of $\mathrm{O}_{2}$ under alternating light and darkness, this cyanobacterium would fix $\mathrm{N}_{2}$ during the period of illumination. In this respect it would resemble cultures of Gloeothece grown under anoxic conditions $[20,60]$.

\subsubsection{Natural populations}

There have been few field investigations on the pattern of $\mathrm{N}_{2}$ fixation by non-heterocystous cyanobacteria. In a single study, natural populations of Gloeothece, growing on the wall of a limestone cave, were shown to exhibit a diurnal pattern of $\mathrm{N}_{2}$ fixation virtually identical to that seen in aerobically incubated laboratory batch cultures [92]. However, in a study of $\mathrm{N}_{2}$ fixation and photosynthesis in North Sea microbial mats, Villbrandt et al. (1990) showed that diel variations of photosynthesis, $\mathrm{N}_{2}$ fixation and $\mathrm{O}_{2}$ concentrations in the mat depended strongly on the type of mat, the season and the prevailing weather conditions [114]. Nevertheless, in all cases, activity was either low or completely absent during daytime. Fluctuations in $\mathrm{O}_{2}$ concentration were an important factor controlling nitrogenase activity in the mat [114]. Microbial mats that contained low biomass (freshly colonized sediment) showed low rates of respiratory $\mathrm{O}_{2}$ consumption during the night. The cyanobacterial mat remained oxic throughout the night although the concentration of $\mathrm{O}_{2}$ was below air saturation. During the day, these mats were often supersaturated with $\mathrm{O}_{2}$, even though the total rate of photosynthesis in the mat was low. On the other hand, the specific rate of photosynthesis (based on the chlorophyll $a$ content) was high. Such conditions are not very suitable for non-heterocystous $\mathrm{N}_{2}$-fixing cyanobacteria which possess a limited capacity for protecting nitrogenase from inhibition by $\mathrm{O}_{2}$. On the other hand, during the night, when photosynthetic $\mathrm{O}_{2}$ evolution had ceased and the prevailing concentration of $\mathrm{O}_{2}$ had declined, $\mathrm{N}_{2}$ fixation could take place, supported by aerobic respiration. These early stages of microbial mat development often showed a characteristic diel variation of $\mathrm{N}_{2}$ fixation similar to that seen in laboratory cultures, with nitrogenase activity confined exclusively to the dark period.

In more mature mats, an interesting observation was that nitrogenase activity peaked at sunrise. This may be explained by the combination of low light intensity (and a resulting low rate of photosynthetic $\mathrm{O}_{2}$ evolution) coupled with a low endogenous concentration of $\mathrm{O}_{2}$. Nevertheless, irradiation provided enough energy to support nitrogenase activity. So far, however, this pattern of behaviour has not been confirmed in laboratory cultures. Culture experiments in which sunrise and sunset are modelled are rare and have not been used for studies of $\mathrm{N}_{2}$ fixation in cyanobacteria. The importance of such experiments has been stressed by Stal and Heyer (1987) [229]. These authors cultured the non-heterocystous cyanobacterium $O$. limosa diazotrophically under an alternating light/dark cycle, applying anoxic conditions during the dark period. This regime was chosen to model the situation in an established microbial mat. In contrast with mats in an early stage of development, established mats contained high biomass and rapidly turned anoxic when photosynthesis ceased. Cultures of $O$. limosa, grown under a light/dark cycle and given anoxic conditions during the dark period, showed nitrogenase activity mainly at the transitions from dark to light and from light to dark. The former peak (sunrise) was the more pronounced. At the transition from light to dark (sunset), nitrogenase was induced but after a short time activity strongly declined because of the absence of $\mathrm{O}_{2}$. O. limosa is capable of fermentation of its storage carbohydrate [230] but the energy that is gained from this metabolism is not sufficient to cover the demands of nitrogenase activity. When illumination commenced, a huge peak of nitrogenase activity was seen. $\mathrm{N}_{2}$ fixation was driven by light energy in an, initially, low $\mathrm{O}_{2}$ environment. However, within a short time nitrogenase was inactivated by photosynthetically evolved $\mathrm{O}_{2}$. This type of diel pattern of $\mathrm{N}_{2}$ fixation mimics that in established North Sea microbial mats $[88,114]$. Similar results were ob- 
tained with cultures of another strain of Oscillatoria, UCSB8, [92], even though in its natural salt marsh habitat this organism fixed $\mathrm{N}_{2}$ exclusively at night.

Natural populations of the planktic, marine cyanobacterium Trichodesmium fix $\mathrm{N}_{2}$ exclusively during the day. This pattern reflects the synthesis of nitrogenase each morning and degradation each evening $[52,65]$, though superimposed upon this is the modification of the Fe-protein of nitrogenase. At the peak of nitrogenase activity, around noon, the Feprotein is almost exclusively in its 'unmodified' form. 'Modified' Fe-protein appears subsequently as nitrogenase activity declines during the later part of the day [132].

It is tempting to interpret current data on $\mathrm{N}_{2}$ fixation by natural populations of non-heterocystous cyanobacteria solely in terms of the temporal separation of $\mathrm{N}_{2}$ fixation and oxygenic photosynthesis. After all, in many systems, $\mathrm{N}_{2}$ fixation is confined to the night, whilst cultures of most non-heterocystous cyanobacteria grown in the laboratory under alternating light/dark cycles show the same behaviour. This does not mean, however, that a temporal separation between $\mathrm{N}_{2}$ fixation and photosynthetic $\mathrm{O}_{2}$ evolution is the critical mechanism that allows non-heterocystous cyanobacteria to fix $\mathrm{N}_{2}$. Several observations do not fit this model. Firstly, in certain microbial mats, diel variations of $\mathrm{N}_{2}$ fixation are less pronounced and they show considerable activity during daytime illumination $[89,93]$. Secondly, natural populations of Trichodesmium, and possibly some other non-heterocystous cyanobacteria, fix $\mathrm{N}_{2}$ exclusively during the day [65]. Thirdly, laboratory cultures of Gloeothece can be grown under conditions where they fix $\mathrm{N}_{2}$ predominantly during the light period of an alternating light/dark cycle $[20,60,226,227]$. It should also not be forgotten that cultures of non-heterocystous cyanobacteria can fix $\mathrm{N}_{2}$ in the laboratory under continuous illumination.

Among those microbial mats that do not show the distinct daily variations of $\mathrm{N}_{2}$ fixation that characterize North sea microbial mats [114] are the mats of Shackleford and Bird Shoal Banks, North Carolina, USA, [89,231] and of Guerrero Negro, Baja California, Mexico (L.J. Stal, unpublished observations). These mats show considerable nitrogenase activity during the daytime. The North Sea, North Carolina and Baja California mats are all built by the same morphotype of cyanobacterium (Oscillatoria limosal Lyngbya aestuarii). This cyanobacterium has been isolated from all of these mats and has been shown to be capable of diazotrophic growth under fully photoautotrophic conditions [37,42]. The morphologies of $O$. limosa and $L$. aestuarii are very similar and they probably represent a single species. This idea is also supported by the fact that the behaviour of nitrogenase in all of these isolates is the same. They are capable of diazotrophic growth under photoautotrophic conditions in continuous light. Nevertheless, when alternating light/dark cycles are applied, nitrogenase activity is confined to the dark period [37,223]. Such behaviour is in contradiction with the field situation in the mats of North Carolina and Baja California, where the differences between day and nighttime nitrogenase activity are less pronounced. The reason for this discrepancy is not clear but several explanations are possible. For example, it cannot be excluded that heterotrophic bacteria contribute to the observed nitrogenase activity in the natural environment. In support of this, Pearl and Prufert (1987) suggested that highly reduced microzones are the sites of $\mathrm{N}_{2}$ fixation [232], whilst stimulation of nitrogenase activity by addition of organic compounds hints of an involvement of chemotrophic bacteria in this process. However, a systematic study (B. Bebout et al., personal communication) on mats of Bird Shoal, North Carolina, has convincingly demonstrated that cyanobacteria were the predominant $\mathrm{N}_{2}$-fixing agents. This has confirmed the earlier experiments of Stal et al. (1984) [88]. In these mats maximum specific activities of nitrogenase corresponded well with maximum rates observed in cultures of $O$. limosa [114].

A spatial separation of $\mathrm{N}_{2}$ fixation and oxygenic photosynthesis within the microbial mat would explain the presence of activity during the daytime. Light is strongly attenuated in the mat but the extent of attenuation is wavelength dependent $[81,233,234]$. Far red light penetrates the mat better than the rest of the visible spectrum. This would result in a higher activity of the anoxygenic Photosystem I relative to that of the oxygenic Photosystem II and, therefore, to anoxic or virtually anoxic conditions. In culture, $O$. limosa shows high nitrogenase activities when irradiated with far red light of $700 \mathrm{~nm}$ under anoxic conditions [235]. Furthermore, specific activities of 
nitrogenase in North Sea microbial mats (on the basis of chlorophyll $a$ content) increased with depth [88]. Similar observations were made by Pearson et al. (1979) for a mat of Microcoleus (Symploca) chthonoplastes [38]. One possibility is that the cyanobacteria in the deeper layers carry out anoxygenic photosynthesis [236]. However, this capacity is by no means universal among cyanobacteria and it is uncertain whether cyanobacteria capable of anoxygenic photosynthesis actually occur in these microbial mats. For instance, $M$. chthonoplastes is capable of anoxygenic photosynthesis but has a requirement for $\mathrm{O}_{2}$ [237]. O. limosa resists considerable levels of sulphide, and is even able to oxidize this compound, but cannot perform anoxygenic photosynthesis [238]. In addition, in many coastal microbial mats with high nitrogenase activity, the concentration of free sulphide is usually low. Moreover, cyanobacteria are most likely unable to compete effectively for sulphide with anoxygenic phototrophs [239]. The other possibility is that the cyanobacteria move up and down the mat according to their nutritional status. It is well documented that cyanobacteria may move up and down in a microbial mat as a result of phototactic and/or chemotactic responses [240] but whether such movements could be controlled by the nitrogen status of the organisms needs to be demonstrated.

In addition to spatial separation of $\mathrm{O}_{2}$ evolution and $\mathrm{N}_{2}$ fixation in different regions within cyanobacterial mats, there is evidence that Lyngbya aestuarii may confine active nitrogenase to photosynthetically inactive terminal regions of individual filaments of this cyanobacterium [37].

\subsection{ATP and reductant}

$\mathrm{N}_{2}$ fixation requires ATP and a powerful reductant. Although the supply of ATP and reductant to nitrogenase has not specifically been studied in nonheterocystous cyanobacteria except for Gloeothece $[20,187,196]$, certain general conclusions can be drawn from the conditions under which these organisms fix $\mathrm{N}_{2}$. Among strains that fix $\mathrm{N}_{2}$ only under anoxic or micro-oxic conditions, sustained $\mathrm{N}_{2}$ fixation and diazotrophic growth have been reported only in Plectonema boryanum [126,170,172,217]. At low light intensities this cyanobacterium simulta- neously performs photosynthesis and $\mathrm{N}_{2}$ fixation [170] and, under these conditions, reductant and/or ATP are probably provided directly by photosynthesis. However, at higher light intensities, photosynthetic $\mathrm{O}_{2}$ evolution, and therefore non-cyclic generation of ATP and reductant, was low during the period of maximum $\mathrm{N}_{2}$ fixation [169]. Supply of ATP and reductant under these conditions may therefore come, at least in part, from catabolism of endogenous carbon reserves. P. boryanum can also use exogenously supplied carbon sources, catabolism of which may supply ATP and reductant for nitrogenase activity [172,173]. Addition of glycollate to cultures of $P$. boryanum doubles nitrogenase activity [220]. The catabolic pathway of endogenous or exogenously supplied sugars is, however, uncertain. It is also not known whether Photosystem I-mediated cyclic photophosphorylation can occur during the period of active $\mathrm{N}_{2}$ fixation. This process could provide at least some of the ATP, though none of the reductant, needed for $\mathrm{N}_{2}$ fixation. As in heterocystous cyanobacteria [241], the proton motive force may be involved in supporting nitrogenase activity in $P$. boryanum, possibly by facilitating the thermodynamically unfavourable reduction of ferredoxin (needed for $\mathrm{N}_{2}$ fixation) at the expense of NADPH [242]. Alternatively, NADH could reduce ferredoxin in a Photosystem I-mediated process [243,244]. $P$. boryanum contains a ferredoxin $(\mathrm{FdxH})$ that is structurally very similar to a ferredoxin found in heterocysts [245]. This ferredoxin is expressed only under anoxic, nitrogenase-inducing conditions and is an effective electron donor to nitrogenase.

In strains of aerotolerant $\mathrm{N}_{2}$-fixing cyanobacteria that simultaneously photosynthesize and fix $\mathrm{N}_{2}$, photosynthesis may, in theory, directly supply ATP and reductant for $\mathrm{N}_{2}$ fixation, assuming that these processes occur within a single cell type. However, it remains to be demonstrated whether the twin criteria of simultaneous activity and a single location for both photosynthesis and $\mathrm{N}_{2}$ fixation can be met. Even under continuous illumination, many non-heterocystous cyanobacteria temporally separate maximum rates of $\mathrm{N}_{2}$ fixation from maximum rates of photosynthetic $\mathrm{O}_{2}$ evolution. It must, however, be remembered that a low rate of measured $\mathrm{O}_{2}$ production does not necessarily mean that photosynthetic electron transport is low: photoevolved $\mathrm{O}_{2}$ could be 
reassimilated by respiratory activity and there is evidence that, in many non-heterocystous cyanobacteria, fluctuations in respiratory activity parallel those in $\mathrm{N}_{2}$ fixation. Moreover, cyclic electron flow around Photosystem I would generate ATP that could be used for $\mathrm{N}_{2}$ fixation without concomitant $\mathrm{O}_{2}$ production, whilst an input of electrons from a donor other than water could allow photosynthetic production of both reductant and ATP with no $\mathrm{O}_{2}$ evolution. However, attempts to demonstrate a direct role for photosynthesis in the provision of ATP or reductant in Gloeothece growing under continuous illumination proved unsuccessful and it was concluded that $\mathrm{N}_{2}$ fixation, among other anabolic processes, was sustained by non-specific pools of ATP and reductant [187]. These pools could be replenished in the dark by catabolism of, in particular, glucan but, in cultures growing under constant illumination, also by photosynthesis. A much less direct role for photosynthesis in providing ATP and reductant for $\mathrm{N}_{2}$ fixation was therefore envisaged. Maryan et al. (1986), on the basis of the effects of added KCN on $\mathrm{N}_{2}$ fixation, respiration and intracellular ATP and ADP in illuminated cultures of Gloeothece, concluded that respiratory metabolism was the main source of energy for $\mathrm{N}_{2}$ fixation even in the light though, at high light intensities, cyclic photophosphorylation may also provide ATP ([196]; also see [246]).

In non-heterocystous cyanobacteria such as Trichodesmium, Lyngbya majuscula and Synechococcus (Cyanothece) SF1, which may fix $\mathrm{N}_{2}$ during the light phase of a cycle of alternating light and darkness, photosynthesis could directly provide ATP and reductant for $\mathrm{N}_{2}$ fixation. Nothing is known about the spatial distribution of photosynthesis and $\mathrm{N}_{2}$ fixation in either Synechococcus SF1 or Lyngbya majuscula. However, in Trichodesmium it is clear that components of the photosynthetic apparatus (phycobiliproteins and Rubisco) coexist with nitrogenase in the same cells $[51,200]$. This does not, of course, mean that the entire photosynthetic system is present and/or functional in these cells and the observation that the putative $\mathrm{N}_{2}$-fixing cells have a reducing environment and a low rate of $\mathrm{CO}_{2}$ fixation $[68,197,198]$ supports, at first sight, the view that they do not produce $\mathrm{O}_{2}$. However, on a colony basis, Trichodesmium exhibits a high rate of respiration which fluctuates in parallel with the diurnal cycle of $\mathrm{N}_{2}$ fixation [50,247-249]. This compensates any photosynthetic $\mathrm{O}_{2}$ evolution to the extent that $\mathrm{N}_{2}$ fixing colonies receiving less than 150-200 $\mu \mathrm{mol}$ photons $\mathrm{m}^{-2} \mathrm{~s}^{-1}$ would exhibit net $\mathrm{O}_{2}$ consumption rather than evolution [249]. Part of this $\mathrm{O}_{2}$ consumption may be light-dependent: a consequence of the Mehler reaction [248]. $\mathrm{O}_{2}$ scavenging through respiration may be particularly efficient in $\mathrm{N}_{2}$-fixing cells, which contain higher concentrations of cytochrome oxidase than do cells lacking nitrogenase [212]. It cannot be excluded, therefore, that $\mathrm{N}_{2}$ fixation and a cryptic oxygenic photosynthesis coexist in a single cell type in Trichodesmium and, as a consequence, that photosynthesis may directly supply ATP and reductant for $\mathrm{N}_{2}$ fixation. On the other hand, since DCMU stimulated $\mathrm{N}_{2}$ fixation when added to Trichodesmium [12], it seems likely not only that some photosynthetically produced $\mathrm{O}_{2}$ was inhibiting nitrogenase but also that alternative sources of reductant are available in $\mathrm{N}_{2}$-fixing cells of Trichodesmium.

Cultures of Gloeothece, fixing $\mathrm{N}_{2}$ during the dark phase of a cycle of alternating light and darkness, generate the necessary ATP and reductant through glucan catabolism [210]. Similarly, in Cyanothece spp, degradation of carbohydrate (probably glycogen) granules supports $\mathrm{N}_{2}$ fixation in cultures growing under alternating light and darkness [221]. In Synechococcus (Cyanothece) strain BG 43511, degradation of carbohydrate coincided with the period of $\mathrm{N}_{2}$ fixation [228]. Moreover, addition of glucose or pyruvate could restore nitrogenase activity to cultures whose intracellular carbon reserves were expended [250]. Glucan degradation probably occurs via the oxidative pentose phosphate pathway in these cyanobacteria, as is certainly the case in photoheterotrophically growing cultures of Oscillatoria strain UCSB8 [46]. As in heterocystous cyanobacteria (see for example, [244,251]), NADPH generated by the initial reactions of the oxidative pentose phosphate pathway (catalysed by glucose-6-phosphate dehydrogenase and 6-phosphogluconate dehydrogenase) and/ or the Entner-Doudoroff pathway (glucose-6-phosphate dehydrogenase) may supply reductant to nitrogenase. This would occur via reduction of ferredoxin, the immediate electron donor to nitrogenase. Alternatively, non-photosynthetic sources such as 
NADPH-dependent isocitrate dehydrogenase [252] and pyruvate:Fd oxidoreductase [253] could also generate reduced ferredoxin in Gloeothece. The most abundant ferredoxin in Gloeothece has a mid point redox potential (Em) close to $-340 \mathrm{mV}$, a value considerably less negative than that of other ferredoxins $(-390$ to $-425 \mathrm{mV}$; see [20]). Such a ferredoxin would be comparatively easier to reduce by NADPH $(\mathrm{Em}=-320 \mathrm{mM})$, but electron donation to nitrogenase $(E m=-460 \mathrm{mV})$ would be thermodynamically unfavourable $[20,164]$. However, this step in Gloeothece may be facilitated by the proton motive force, in a manner similar to the reported reduction of ferredoxin by NADPH in $P$. boryanum [242]. The stimulation of nitrogenase activity in Gloeothece, observed in the presence of 2,4-dinitrophenol and shown to be independent of any effect on the intracellular ratio of ADP to ATP [20], may be related to an effect of membrane electrogenesis (probably the membrane potential, $\Delta \psi$ ) on the provision of reductant for $\mathrm{N}_{2}$ fixation.

On the other hand, in cultures of Gloeothece that were fixing $\mathrm{N}_{2}$ only during the light phase of a light/ dark cycle (for example when grown either under anoxic conditions [20] or in aerobic continuous culture [226]), photosynthesis may be the direct source of ATP and reductant. However, as with cultures grown under continuous illumination, any such direct link has not been proved, though the observation that the intracellular concentration of glucan did not fluctuate greatly in cultures of Gloeothece growing under alternating light and darkness in continuous culture [226] is consistent with the idea that photosynthesis may directly supply nitrogenase with ATP and reductant under these conditions. On the other hand, Synechococcus (Cyanothece) strain BG 43511, like Gloeothece, fixes $\mathrm{N}_{2}$ during the light period when grown under alternating light and darkness in the absence of $\mathrm{O}_{2}$. Nevertheless, in cultures grown under these conditions, $\mathrm{N}_{2}$ fixation coincided with a net degradation of carbohydrate [228].

Only in Oscillatoria limosa has $\mathrm{N}_{2}$ fixation been observed in the dark under strict anoxic conditions. Here, reductant and ATP may be generated by fermentation [229].

\section{4. $\mathrm{N}_{2}$ fixation and $\mathrm{O}_{2}$}

A major factor that has attracted scientists to the study of $\mathrm{N}_{2}$ fixation in non-heterocystous cyanobacteria has been the apparent paradox of organisms that simultaneously fix $\mathrm{N}_{2}$ and photoevolve $\mathrm{O}_{2}$. In practice, however, it appears unlikely that this situation ever actually occurs: these organisms separate the two incompatible processes of oxygenic photosynthesis and $\mathrm{N}_{2}$ fixation either in time or in space. Currently, there is no evidence that any known $\mathrm{N}_{2}$ fixing non-heterocystous cyanobacterium catalyses oxygenic photosynthesis and $\mathrm{N}_{2}$ fixation simultaneously within a single cell. That does not mean, however, that this situation does not occur in one or more strain incubated in the laboratory under continuous illumination or in Trichodesmium, Synechococcus SF1, Lyngbya majuscula, Plectonema boryanum, or anoxic or sulphur-replete cultures of Gloeothece incubated under alternating light and darkness. However, it has not categorically been demonstrated that this is so.

Nevertheless, it is reasonable to assume that nonheterocystous cyanobacteria possess particularly efficient mechanisms for limiting $\mathrm{O}_{2}$ damage to nitrogenase. A wide variety of strategies are known by which diazotrophs, including non-heterocystous cyanobacteria, protect nitrogenase from inactivation by $\mathrm{O}_{2}$ and it is not intended to do more than summarise these here. For more details see the reviews by Fay (1992) [7] and Gallon (1992) [8].

There is probably a gradation of tolerance to $\mathrm{O}_{2}$ among non-heterocystous $\mathrm{N}_{2}$-fixing cyanobacteria. Some strains can fix $\mathrm{N}_{2}$ aerobically and can therefore protect their nitrogenase from inactivation by both photosynthetically generated $\mathrm{O}_{2}$ and the 0.21 atm of $\mathrm{O}_{2}$ present in air. Those that cannot would, by definition, fix $\mathrm{N}_{2}$ only when the prevailing concentration of $\mathrm{O}_{2}$ was low, or even zero. However, among these strains, there will almost certainly be variations in the maximum concentration of $\mathrm{O}_{2}$ to which they can be exposed without inhibiting $\mathrm{N}_{2}$ fixation completely. For example, van der Oost et al. (1987) showed that, among unicellular cyanobacteria, $\mathrm{N}_{2}$ fixation by Synechococcus (Cyanothece) PCC 7425 was more sensitive to $\mathrm{O}_{2}$ than $\mathrm{N}_{2}$ fixation in Cyanothece PCC 7822 and both were more sensitive than $\mathrm{N}_{2}$ fixation in the aerotolerant Gloeothece PCC 6909 
[203]. Similarly, Synechococcus (Cyanothece) strain $\mathrm{RF}-1$ is less tolerant of $\mathrm{O}_{2}$ than Gloeothece, since cultures of this cyanobacterium grow diazotrophically under air only in standing culture [28,254]. However, even in aerotolerant diazotrophic cyanobacteria, the mechanisms that function to protect nitrogenase from inactivation by $\mathrm{O}_{2}$ may be saturated at concentrations of $\mathrm{O}_{2}$ greater than those in air.

Mechanisms that non-heterocystous cyanobacteria use in order to minimize the deleterious effects of $\mathrm{O}_{2}$ on $\mathrm{N}_{2}$ fixation include behavioural strategies, physical barriers and metabolic strategies.

Behavioural strategies include avoidance of $\mathrm{O}_{2}$, a strategy that is practised by those cyanobacteria that fix $\mathrm{N}_{2}$ under anoxic or micro-oxic conditions. They are found in environments where the prevailing concentration of $\mathrm{O}_{2}$ is low, as well as in specialized environments like sulphur springs and waterlogged soil. $\mathrm{N}_{2}$ fixation by non-heterocystous cyanobacteria often occurs in microbial aggregates where anoxic microenvironments occur (see Section 6.2.2. The temporal separation of photosynthesis and $\mathrm{N}_{2}$ fixation in most non-heterocystous cyanobacteria exposed to alternating light and darkness may also be considered as a behavioural strategy for limiting $\mathrm{O}_{2}$ inactivation of nitrogenase.

The best known example of a barrier to $\mathrm{N}_{2}$ fixation is found in heterocystous cyanobacteria. The heterocyst cell wall is relatively impermeable to atmospheric gases [255]. $\mathrm{N}_{2}$ is four times as abundant as $\mathrm{O}_{2}$ in the atmosphere, so sufficient $\mathrm{N}_{2}$ can enter the heterocyst to sustain measured rates of $\mathrm{N}_{2}$ fixation. However, any $\mathrm{O}_{2}$ that penetrates this barrier is consumed by respiratory metabolism. In this way, a virtually anoxic environment surrounds nitrogenase. In theory, the same situation may apply in non-heterocystous cyanobacteria that effect a spatial separation between $\mathrm{N}_{2}$ fixation and oxygenic photosynthesis but, as explained above, the situation is less clear cut in these organisms. Many cyanobacteria are surrounded by extracellular polysaccharide material. This is particularly evident in the extensive sheath that surrounds the unicellular cyanobacterium Gloeothece and the filamentous cyanobacteria Lyngbya, Phormidium and Microcoleus (Symploca) chthonoplastes. Whether such sheaths act as a barrier to the influx of atmospheric gases is unclear and sheathless strains of Gloeothece are known that show a normal sensitivity of $\mathrm{N}_{2}$ fixation to $\mathrm{O}_{2}$ [58]. However, although such strains clearly lack the laminated sheath that characterizes Gloeothece, they are not completely devoid of extracellular polysaccharide (S.V. Shestakov, L.J. Stal and J.R. Gallon, unpublished observations). Moreover, in any cultures that are simultaneously fixing $\mathrm{N}_{2}$ and photoevolving $\mathrm{O}_{2}$, a surrounding barrier to the diffusion of gases would be as much a problem as an asset. On the other hand, coupled with a temporal separation between $\mathrm{N}_{2}$ fixation and photosynthesis, an external barrier that limits gas exchange could benefit the process of $\mathrm{N}_{2}$ fixation in non-heterocystous cyanobacteria, as in heterocystous cyanobacteria.

The $\mathrm{N}_{2}$-fixing nodules of legumes contain an $\mathrm{O}_{2}$ binding protein, leghaemoglobin, whose function is to deliver bound $\mathrm{O}_{2}$ to Rhizobium-infected tissue in order to sustain oxidative phosphorylation. The concentration of free $\mathrm{O}_{2}$ in the infected zone of the nodule remains very low $(11 \mathrm{nM})$ thereby avoiding $\mathrm{O}_{2}$ inactivation of nitrogenase (for more details, see [8] and references cited therein). A similar protein (GlbN, now designated cyanoglobin) has been found in the heterocystous cyanobacterium Nostoc commune [256]. Cyanoglobin is encoded by a gene $(g l b N)$ that is positioned amid some of the nif genes and this protein may therefore have an $\mathrm{O}_{2}$-scavenging role in $\mathrm{N}_{2}$ fixation. In support of this, synthesis of cyanoglobin was induced by nitrogen starvation and incubation under micro-oxic conditions. A survey of 41 cyanobacteria (40 of which were diazotrophs), using a $g l b N$ gene probe and antibodies raised against cyanoglobin, revealed that this protein was present in many, though not all, heterocystous species. For example, it was missing from the eleven strains of Anabaena tested. On the other hand, cyanoglobin was not detected in the non-heterocystous cyanobacteria Synechococcus PCC 7942, Synechocystis BO 8402, Chroococcidiopsis, Oscillatoria PCC 7515, Phormidium strains SAUG B1462-1 and B1442-1 or Pseudanabaena PCC 7403, though it was found in Trichodesmium (M. Potts et al., personal communication). Attempts to detect cyanoglobin in extracts of aerobically grown Gloeothece, using antisera to the protein from $N$. commune, were also unsuccessful (J.P.H. Reade, L.J. Rogers and J.R. Gallon, unpublished finding). The distribution of cy- 
anoglobin is not therefore universal among either heterocystous or non-heterocystous $\mathrm{N}_{2}$-fixing cyanobacteria. Moreover, this protein appears not to be obligatory for $\mathrm{N}_{2}$ fixation (K. Jäger; M. Potts et al., personal communications).

A number of metabolic strategies are employed by non-heterocystous cyanobacteria in order to cope with $\mathrm{O}_{2}$. For example, metabolic consumption of $\mathrm{O}_{2}$ seems of great importance in maintaining a relatively low concentration of intracellular $\mathrm{O}_{2}$ in a number of cyanobacteria, including Gloeothece [195], Synechococcus (Cyanothece) spp. [27], Microcoleus (Symploca) chthonoplastes [39] and Oscillatoria spp. $[46,235,257]$. In many cases, the pattern of respiratory activity parallels that of $\mathrm{N}_{2}$ fixation in cultures grown under alternating light and darkness or under continuous illumination.

When studying $\mathrm{O}_{2}$ consumption, it is the sum of all the individual $\mathrm{O}_{2}$-consuming reactions that is measured. These individual reactions can be diverse, and include substrate level oxidase activity (for example that of glycollate oxidase) or $\mathrm{O}_{2}$ consumption linked to aerobic electron transport chains. Such chains may be branched, and have a number of different terminal oxidases (such as $a$-, $d$ - or $o$-type cytochromes) and also a variety of electron donors (for example, pyridine or flavin nucleotides linked to carbon metabolism, or ferredoxins linked to carbon metabolism or $\mathrm{H}_{2}$ ). Both carbon-linked and $\mathrm{H}_{2}$ linked respiratory $\mathrm{O}_{2}$ consumption are known among non-heterocystous cyanobacteria. For details, see [8].

Oxidases may reduce $\mathrm{O}_{2}$ either to $\mathrm{H}_{2} \mathrm{O}$ (water: a four-electron reduction), to $\mathrm{H}_{2} \mathrm{O}_{2}$ (hydrogen peroxide: a two-electron reduction) or to $\mathrm{O}_{2}{ }^{-}$(superoxide: a one-electron reduction). The last two products can, however, give rise to a variety of reactive $\mathrm{O}_{2}$ derived radicals and are viewed as very dangerous species. Non-heterocystous cyanobacteria, like other aerobes, therefore possess a battery of enzymes that act to destroy $\mathrm{H}_{2} \mathrm{O}_{2}$ and $\mathrm{O}_{2}{ }^{-\cdot}$. These have been most extensively studied in Gloeothece [8]. Whilst these enzymes would function to limit $\mathrm{O}_{2}$-induced damage of a wide range of biomolecules, not just nitrogenase, it is interesting that, in the heterocystous cyanobacterium Anabaena PCC 7120, the gene encoding one of these enzymes, glutathione reductase, contains an NtcA (BifA) binding site in its promoter region
[182], thereby implying that its transcription may be regulated through nitrogen status.

Perhaps the most intriguing possibility to have emerged in recent years is that nitrogenase may participate in protecting itself from inactivation by $\mathrm{O}_{2}$. Nitrogenase is a versatile enzyme that can reduce a variety of substrates in addition to $\mathrm{N}_{2}$. These substrates include acetylene $\left(\mathrm{C}_{2} \mathrm{H}_{2}\right)$, the basis of the widely used acetylene reduction assay for nitrogenase activity, $\mathrm{NO}_{2}{ }^{-}$[258], $\mathrm{CO}_{2}$ [259] and $\mathrm{O}_{2}$ [260]. When present in vitro at a concentration greater than four times that of $\mathrm{O}_{2}$, the reduced form of the Fe-protein of nitrogenase (acting as a complex with two molecules of $\mathrm{MgADP}^{-}$) reduces $\mathrm{O}_{2}$ to $\mathrm{H}_{2} \mathrm{O}_{2}$ and $\mathrm{H}_{2} \mathrm{O}$ (Reaction 3, Fig. 3b). The second stage of this reaction, reduction of $\mathrm{H}_{2} \mathrm{O}_{2}$ to $\mathrm{H}_{2} \mathrm{O}$, is very slow and catalase or peroxidases may be required to prevent accumulation of $\mathrm{H}_{2} \mathrm{O}_{2}$ in vivo. When the concentration of $\mathrm{O}_{2}$ exceeds that of the Fe-protein, $\mathrm{O}_{2}$ is reduced to $\mathrm{O}_{2}{ }^{-*}$, which inactivates nitrogenase and other biomolecules (Reaction 2, Fig. 3b). Thus, whether the ability of nitrogenase to consume $\mathrm{O}_{2}$ could protect itself from inactivation ('autoprotection') depends critically upon the prevailing relative concentrations of $\mathrm{O}_{2}$ and $\mathrm{Fe}$-protein and also on the presence of $\mathrm{H}_{2} \mathrm{O}_{2}$-removing peroxidases. Catalase would be a poor substitute for peroxidases in this context because the breakdown of $\mathrm{H}_{2} \mathrm{O}_{2}$ catalysed by catalase would regenerate some of the $\mathrm{O}_{2}$ originally consumed (Fig. 3). The efficiency of 'autoprotection' would also be affected by the relative concentrations of ATP and ADP in the cells since the complex between $\mathrm{Fe}$-protein and $\mathrm{MgATP}^{2-}$ was less effective at reducing $\mathrm{O}_{2}$ to $\mathrm{H}_{2} \mathrm{O}_{2}$ than was the $\mathrm{Fe}$ protein: $\mathrm{MgADP}^{-}$complex. Moreover, unlike the Fe-protein:MgADP ${ }^{-}$complex, the complex with $\mathrm{MgATP}^{2-}$ could also transfer electrons to the MoFe-protein for subsequent reduction of $\mathrm{N}_{2}$ (Reaction 1, Fig. 3b). The situation is therefore complex but 'autoprotection' may in theory function under appropriate conditions if the nitrogenase-containing cells can keep the Fe-protein in a functionally reduced state. It has, for example, been calculated that the intracellular conditions are such that 'autoprotection' might function in practice in cultures of the aerobic heterotroph Azotobacter to limit the damaging effect of $\mathrm{O}_{2}$ on nitrogenase [260,261].

There is no direct evidence for 'autoprotection' of 
$\mathrm{N}_{2}$ fixation in cyanobacteria. However, theory suggests that it may have a role in the heterocysts of heterocystous cyanobacteria where the prevailing concentration of $\mathrm{O}_{2}$ is already low. Elhai and Wolk (1991) have presented preliminary data suggesting that the concentration of $\mathrm{O}_{2}$ in heterocysts of Anabaena was about $0.6 \mu \mathrm{M}$ [262]. To provide a four-fold excess, the Fe-protein would have to be present at a concentration of $2.4 \mu \mathrm{M}$, or $0.173 \mathrm{mg}$ $\mathrm{ml}^{-1}$ (assuming an $M_{\mathrm{r}}$ of 72000 for this protein). Heterocysts vary in size but $7 \mu \mathrm{m}$ diameter appears typical of many Anabaena strains [96]. This gives a volume of about $180 \mu \mathrm{m}^{3}\left(1.8 \times 10^{-10} \mathrm{ml}\right)$. A single heterocyst would therefore have to contain $30 \mathrm{fg}$ of $\mathrm{Fe}$-protein in order for the basic conditions of 'autoprotection' to apply. If it is assumed that the protein content of a cyanobacterium with cells of this size is $0.1 \mathrm{mg}\left(10^{6} \text { cells }\right)^{-1}$, which is the case in Gloeothece [210], and that the protein content of a heterocyst is similar to that of a vegetative cell, then each heterocyst contains approximately $100 \mathrm{pg}$ of protein. For 'autoprotection' of $\mathrm{N}_{2}$ fixation to function, the Fe-protein would thus have to constitute $0.03 \%$ of the total protein of a heterocyst. Since the $\mathrm{Fe}$-protein is readily detectable in SDS/PAGE gels of heterocyst proteins [263], it seems quite likely that the actual amount of this protein in heterocysts is much greater than $0.03 \%$ of the total. In theory, therefore, 'autoprotection' may contribute to protection of nitrogenase from $\mathrm{O}_{2}$ damage in heterocystous cyanobacteria.

In the case of a non-heterocystous cyanobacterium such as Gloeothece, a similar calculation can be made. Typical Gloeothece cells are $6 \mu \mathrm{m} \times 10 \mu \mathrm{m}$ (Plate 1a). This gives a cell volume of $225 \mu \mathrm{m}^{3}$ $\left(2.25 \times 10^{-10} \mathrm{ml}\right)$, which corresponds reasonably well with that of $2.79 \times 10^{-10} \mathrm{ml}$ actually measured (M. Davey and J.R. Gallon, unpublished) by monitoring the uptake of ${ }^{3} \mathrm{HOH}$, which readily enters cells, and $\left[\mathrm{U}_{-}{ }^{14} \mathrm{C}\right]$ sorbitol, which enters the periplasmic space but does not cross the plasmalemma [241]. Assuming that the Fe-protein of nitrogenase constitutes $0.5 \%$ of the total protein (which is the most that appears likely by inspection of stained SDS/ PAGE gels), then an individual cell of Gloeothece is unlikely to contain more than $0.5 \mathrm{pg}$ of Fe-protein. The subunits of the homodimeric Gloeothece Fe-protein have an $M_{\mathrm{r}}$ of 38500 ('unmodified') or 40000 ('modified'). Taking a median value of 78500 for the dimer, and assuming a cell volume of $2.5 \times 10^{-10} \mathrm{ml}$, each cell would contain 6.4 amol of Fe-protein at a concentration of $26 \mu \mathrm{M}$. 'Autoprotection' could therefore function in Gloeothece, but only if the intracellular concentration of $\mathrm{O}_{2}$ was maintained by other processes at $6.5 \mu \mathrm{M}$ or less (for comparative purposes, it should be noted that air-saturated water has a dissolved $\mathrm{O}_{2}$ concentration of $258 \mu \mathrm{M}$ at $25^{\circ} \mathrm{C}$ ). The absolute value of the intracellular concentration of $\mathrm{O}_{2}$ in Gloeothece is not known though fluctuations in the relative concentration have been measured [264]. These show that intracellular $\mathrm{O}_{2}$ is extremely low during the maximum phase of $\mathrm{N}_{2}$ fixation in cultures growing under alternating light and darkness (C. Du, C.J. Restall and J.R. Gallon, unpublished findings). Furthermore, immediately following the maximum of nitrogenase activity (about $6 \mathrm{~h}$ into the dark phase), the intracellular ratio of ADP to ATP rises from about 0.6 to as high as 3 [210]. These conditions would also favour the operation of 'autoprotection' at a time when it is most needed, since at this time nitrogenase synthesis has ceased and $\mathrm{O}_{2}$-inactivated enzyme cannot be replaced by de novo synthesis. However, 'autoprotection' requires a source of reductant, and this may well be limited during the latter stages of the dark period because of exhaustion of usable glucan reserves. It is difficult therefore to assess the impact, if any, of 'autoprotection' on $\mathrm{N}_{2}$ fixation in cultures of Gloeothece.

It should also be stressed that, during the operation of 'autoprotection', electrons delivered to the Fe-protein of nitrogenase are diverted to $\mathrm{O}_{2}$ and away from the MoFe-protein of nitrogenase (Fig. 3a). $\mathrm{N}_{2}$ reduction would therefore be proportionally inhibited. However, a temporary loss of $\mathrm{N}_{2}$ fixation during a transient period of $\mathrm{O}_{2}$ stress may be preferable to an irreversible inactivation of nitrogenase. A temporary loss of nitrogenase activity during transient $\mathrm{O}_{2}$ stress has been reported in Oscillatoria limo$s a$ [235]. Recovery was independent of nitrogenase synthesis. This is consistent with the operation of 'autoprotection' in this organism under conditions when the other $\mathrm{O}_{2}$-consuming reactions are saturated but the intracellular concentration of $\mathrm{O}_{2}$ does not exceed a value consistent with the functioning of the $\mathrm{Fe}$-protein as a harmless $\mathrm{O}_{2}$-consuming enzyme. 
In Gloeothece, there are also reports of a synthesisindependent recovery of nitrogenase from transient exposure to $0.8 \mathrm{~atm}$ of $\mathrm{O}_{2}$ [195], though recovery of nitrogenase from exposure to 1 atm of $\mathrm{O}_{2}$ usually depends upon protein synthesis [195,265]. Indeed, synthesis of nitrogenase, in order to replace $\mathrm{O}_{2}$-inactivated enzyme is probably an important component of the mechanisms that allow this cyanobacterium to fix $\mathrm{N}_{2}$ aerobically [8]. Nevertheless, it is possible that 'autoprotection' has a role in the protection of Gloeothece nitrogenase from exposure to $0.8 \mathrm{~atm}$ of $\mathrm{O}_{2}$, though the process may be swamped by exposure to 1 atm of $\mathrm{O}_{2}$.

In Azotobacter spp., transient protection of nitrogenase from exposure to concentrations of $\mathrm{O}_{2}$ that saturate respiratory consumption (including, presumably, 'autoprotection') is provided by the formation of an $\mathrm{O}_{2}$-stable, though catalytically inactive, complex with an iron-sulphur protein, FeSII (for more details, see $[8,266])$. Antisera raised against FeSII failed to react with any Gloeothece protein (J.P.H. Reade, L.J. Rogers and J.R. Gallon, unpublished), so it is assumed that no similar system functions in this cyanobacterium.

In all of the cyanobacteria so far examined, the unidentified modification of the Fe-protein, mentioned above, is stimulated by exposure to elevated $\mathrm{O}_{2}$. However, in Gloeothece, there is no evidence that this modification either allows the protein to function in cultures exposed to elevated $\mathrm{O}_{2}$ or to recover activity spontaneously following transient $\mathrm{O}_{2}$ stress [60].

\section{Circadian rhythms}

The pattern of $\mathrm{N}_{2}$ fixation seen in cultures of nonheterocystous cyanobacteria growing under alternating light and darkness constitutes a diurnal cycle, regardless of whether nitrogenase activity is confined to the light or dark phase. However, many cultures grown under constant illumination also exhibit fluctuations in their rate of $\mathrm{N}_{2}$ fixation. These fluctuations may or may not exhibit a diurnal cycle. For example, successive peaks of nitrogenase activity were separated by about $40 \mathrm{~h}$ in Gloeothece strain CCAP 1430/3 (=PCC 6909) [267] and by about 120 $\mathrm{h}$ in Oscillatoria sp. UCSB8 [46]. On the other hand, cultures of Oscillatoria limosa [223] and Cyanothece BH68 [31], grown under continuous illumination, showed fluctuations in nitrogenase activity with peaks separated by about $24 \mathrm{~h}$. Some strains of Synechococcus (Cyanothece) and Gloeothece apparently show no fluctuations in nitrogenase activity when grown under continuous illumination [19] though, in Synechococcus (Cyanothece) strains RF-1 and BG 43511, the diurnal pattern imposed by exposure to alternating light and darkness persists when cultures are returned to constant illumination $[254,268]$. In many cases, the observed fluctuations in nitrogenase activity correspond to reciprocal fluctuations in net photosynthetic $\mathrm{O}_{2}$ evolution [46,254,257,268].

In Cyanothece strains (including those designated as Synechococcus), the diurnal pattern of $\mathrm{N}_{2}$ fixation may be considered as endogenous in the sense that, once imposed, it persists in cultures removed from the stimulus of alternating light and darkness. In the case of Synechococcus (Cyanothece) strain BG 43511, this circadian rhythm may reflect synchronous cell division, with $\mathrm{N}_{2}$ fixation (and transcription of the nif genes) and oxygenic photosynthesis confined to different phases of the cell cycle $[26,228,269,270]$. Zehr (1995) has speculated that, in Trichodesmium (see Section 6.1, individual trichomes may alternate between phases of oxygenic photosynthesis and $\mathrm{N}_{2}$ fixation and that this, too, may reflect the confinement of these incompatible activities to different phases of a cycle of cell division. However, whilst such behaviour would be consistent with many of the physiological properties of Trichodesmium, it has not yet been directly demonstrated [11]. Moreover, the situation in Synechococcus (Cyanothece) strain BG 43511, is complicated by the observation that apparently endogenous rhythms in $\mathrm{N}_{2}$ fixation and photosynthesis are also seen in non-growing cultures [216]. This implies a regulatory system separate from that proposed to be linked to the cell cycle.

Most studies on the endogenous circadian rhythm of $\mathrm{N}_{2}$ fixation have concentrated on Synechococcus (Cyanothece) strain RF-1 [9,271-276]. There is, however, good evidence that Cyanothece $\mathrm{BH} 68$ may also show endogenous circadian rhythms both in $\mathrm{N}_{2}$ fixation [31] and in carbohydrate deposition [221].

Until relatively recently, circadian rhythms were considered to be restricted to eukaryotes [277]. It is now, however, accepted that this is not the case 
[278]. For example, work with Synechococcus strain PCC 7942 and Synechocystis strain PCC 6803 [279281] has shown that cyanobacteria exhibit circadian rhythms in the expression of many genes, one of which, psbAI (which encodes the D1 protein, an integral component of the reaction centre of Photosystem II) has been more extensively investigated [279].

Synechocystis PCC 6803 and Synechococcus PCC 7942 do not fix $\mathrm{N}_{2}$, but Synechococcus (Cyanothece) RF-1 exhibits circadian rhythms in $\mathrm{N}_{2}$ fixation [272] as well as in amino acid uptake [282], photosynthesis ([283]; Y-J. Shei, unpublished, cited in [9]), protein synthesis [284] and intracellular concentrations of ATP (T-H. Chen, unpublished, cited in [9]). The observed pattern of $\mathrm{N}_{2}$ fixation conforms to the criteria of an endogenous circadian rhythm in that, once established, it persists in the absence of any apparent external signal, it can be reset by altering the pattern of light and darkness that cultures receive [272] and it responds to a pulse of low temperature [274,284]. The circadian rhythm is exerted at the level of transcription of one or more nif gene [155] but nif gene expression is not needed for establishment of the rhythm [273].

However, not all non-heterocystous cyanobacteria exhibit endogenous circadian rhythms in $\mathrm{N}_{2}$ fixation. For example, when grown under alternating $12 \mathrm{~h}$ light and $12 \mathrm{~h}$ darkness, Gloeothece exhibits a diurnal rhythm in nitrogenase activity. However, this pattern is lost on transfer to continuous illumination $[118,267,285]$. This suggests that the $\mathrm{N}_{2}$ fixation rhythm in Gloeothece is more to do with metabolic changes and environmental conditions than with an endogenous circadian clock.

\section{Concluding remarks}

Twenty years ago, it would have been impossible to write a review about $\mathrm{N}_{2}$ fixation in non-heterocystous cyanobacteria. The body of experimental data simply was not there. During the last two decades, however, there has been a burgeoning scientific interest in these organisms. The reasons for this are complex, and centre on a number of factors. Firstly, ever since the observation that $\mathrm{N}_{2}$ fixation was an $\mathrm{O}_{2}$-sensitive process, there has been much interest in determining the mechanisms that diazotrophs use in order to protect nitrogenase from inactivation by $\mathrm{O}_{2}$. Since cyanobacteria actually photoevolve $\mathrm{O}_{2}$, the mechanisms that they possess should, in theory, be more efficient than those of other diazotrophs. Most non-heterocystous cyanobacteria do not confine nitrogenase to non-photosynthetic cells, so these organisms are particularly suitable for such studies. Secondly, non-heterocystous cyanobacteria are the closest surviving relatives of the free-living ancestor of modern chloroplasts that, according to the endosymbiont theory, was assimilated by the heterotrophic organism from which modern eukaryote algae and higher plants evolved. One of the persistent goals of modern research into $\mathrm{N}_{2}$ fixation is the transfer of the ability to fix $\mathrm{N}_{2}$ to the chloroplasts of leaves of non-diazotrophic crop plants, thereby generating strains that do not need a regular supply of expensive, and polluting, nitrogen-based fertilizer. However, in order for this can be achieved, any introduced nif genes should be correctly expressed and the nitrogenase produced in this way must integrate properly with chloroplast metabolism in order to be catalytically active. Whilst chloroplasts could readily generate ATP and reductant for $\mathrm{N}_{2}$ fixation, and carbon skeletons for assimilation of newly fixed nitrogen, they also photoevolve $\mathrm{O}_{2}$, so there is an additional requirement that nitrogenase be protected from $\mathrm{O}_{2}$ damage. All of these problems are already faced, and solved, by free-living non-heterocystous cyanobacteria. Consequently, a thorough understanding of $\mathrm{N}_{2}$ fixation in non-heterocystous cyanobacteria, including its regulation and integration with other metabolic processes, could greatly assist attempts to generate novel $\mathrm{N}_{2}$-fixing crop plants. Thirdly, because $\mathrm{H}_{2}$ is an obligatory by-product of the nitrogenase-catalysed reduction of $\mathrm{N}_{2}$, there has been much recent interest in using $\mathrm{N}_{2}$-fixing cyanobacteria to convert solar energy into industrially useful $\mathrm{H}_{2}$ gas. The fact that most non-heterocystous cyanobacteria would produce $\mathrm{H}_{2}$ at night suggests that they might be a valuable component of any system designed for continuous $\mathrm{H}_{2}$ production using natural illumination, which comes as alternating light and darkness. Fourthly, the more recent appreciation that $\mathrm{N}_{2}$-fixing non-heterocystous cyanobacteria make a substantial contribution to the global nitrogen cycle, especially in the marine environment, has stimulated interest in cyanobacteria such as Tri- 
chodesmium. This interest has been intensified by the finding that Trichodesmium produces a small proportion of unusual cells that appear to act as heterocyst equivalents, even though they lack the structural modifications that, in heterocysts, contribute to the protection of nitrogenase from inactivation by $\mathrm{O}_{2}$.

It is, hopefully, apparent from this review that much has been achieved and that we now have a detailed understanding of some of the metabolic processes related to $\mathrm{N}_{2}$ fixation in non-heterocystous cyanobacteria. Much, for example, is known about the diverse mechanisms that these organisms use in order to protect nitrogenase from inactivation by $\mathrm{O}_{2}$, though it is still not possible to gauge the relative significance of each of these mechanisms in individual cyanobacteria. It almost certainly varies from organism to organism. Rather less is known about some other areas, such as the supply of ATP and reductant to nitrogenase, the regulation of $\mathrm{N}_{2}$ fixation by fixed nitrogen, and the molecular mechanisms underpinning the clear fluctuations in nitrogenase activity seen in cultures growing under alternating light and darkness. However, steady progress is being made and, hopefully, will continue. Much less is known about the control of nif gene transcription by $\mathrm{O}_{2}$ or about the details of $\mathrm{N}_{2}$ fixation in natural populations of non-heterocystous cyanobacteria. Perhaps not surprisingly, given their quantitative significance, most available information concerning natural populations comes from studies in the marine environment, both with planktic strains and with mat-forming cyanobacteria on the littoral fringes of the oceans. Nevertheless, there is a clear need for further studies on these systems as well as in other ecosystems.

Finally, there is probably something fundamental in human nature that makes us concentrate on the unusual at the expense of the commonplace. Certainly, $\mathrm{N}_{2}$ fixation is unusual among non-heterocystous cyanobacteria. Most strains currently known cannot fix $\mathrm{N}_{2}$. For example, in a comprehensive list of cyanobacterial cultures available in the collection of the Pasteur Institute in Paris, no more than about $40 \%$ of the non-heterocystous strains were reported as fixing $\mathrm{N}_{2}$ [22]. Moreover, of those non-heterocystous cyanobacteria that can fix $\mathrm{N}_{2}$, most do so only under anoxic or micro-oxic conditions. Aerobic $\mathrm{N}_{2}$ fixation is very unusual among these organisms. De- spite this, it is the few strains that can fix $\mathrm{N}_{2}$ aerobically that have received extensive scientific study. Representatives of the more numerous non-heterocystous cyanobacteria that can fix $\mathrm{N}_{2}$ only when the prevailing concentration of $\mathrm{O}_{2}$ is low have been comparatively neglected. There is a need to remedy this deficiency. Another, though less dramatic, example of our obsession with things unusual is reflected in the current intensive study of the diel pattern of $\mathrm{N}_{2}$ fixation in Trichodesmium. Whilst it is easy to justify the need to study this organism because of its huge potential for $\mathrm{N}_{2}$ fixation, it should be remembered that it is extremely unusual, if not unique, among aerotolerant non-heterocystous $\mathrm{N}_{2}$-fixing cyanobacteria in that it fixes $\mathrm{N}_{2}$ during the day. Most non-heterocystous cyanobacteria that fix $\mathrm{N}_{2}$ aerobically do so at night.

This unusual behaviour of Trichodesmium itself highlights the need to look at many organisms, not just a select few. Twenty years ago, for want of direct information, scientists assumed that most of the properties of $\mathrm{N}_{2}$ fixation in non-heterocystous cyanobacteria would be fundamentally similar to those in heterocystous strains. Now we are aware that much is different between heterocystous and nonheterocystous cyanobacteria. We have also now become aware that different non-heterocystous cyanobacteria exhibit important differences. Whilst this can be taken as a measure of scientific progress, it emphasizes the need to extend our studies to other neglected strains of non-heterocystous cyanobacteria. For example, nothing is known about $\mathrm{N}_{2}$ fixation in the cyanobacteria of Section II (Table 1), or in those non-heterocystous cyanobacteria that enter into symbiotic associations. Hopefully, this will be remedied. However, it remains to be seen whether the next twenty years of research into $\mathrm{N}_{2}$ fixation by non-heterocystous cyanobacteria will reveal more differences or some general unifying principles. Whatever the final outcome, the undertaking will certainly be worthwhile.

\section{Acknowledgments}

The authors thank the following bodies for financial support for their own work described in this article: in Sweden, the Swedish Natural Science Re- 
search Council, the $\mathrm{C}$. Tryggers foundation and SAREC (B.B.): in the U.K., BBSRC, NERC, the Royal Society and the New Phytologist Trust (J.R.G): and in India, CSIR (A.N.R).

\section{References}

[1] Dugdale, R.C., Menzel, D.W. and Ryther, J.H. (1961) Nitrogen fixation in the Sargasso Sea. Deep-Sea Res., 7, 297-300.

[2] Wyatt, J.T. and Silvey, J.K.G. (1969) Nitrogen fixation by Gloeocapsa. Science, 165, 908-909.

[3] Stewart, W.D.P. and Lex, M. (1970) Nitrogenase activity in the blue-green alga Plectonema boryanum strain 594. Arch. Mikrobiol., 73, 250-260.

[4] Anagnostidis, K. and Komárek, J. (1988) Modern approach to the classification system of cyanophytes. 3. Oscillatoriales. Arch. Hydrobiol., 80, 327-472.

[5] Albertano, P. (1991) Effects of monochromatic lights on four species of Leptolyngbya. Arch. Hydrobiol., 92, 199-214.

[6] Gallon, J.R. and Stal, L.J. (1992) $\mathrm{N}_{2}$ fixation in non-heterocystous cyanobacteria: an overview. In: Marine Pelagic Cyanobacteria: Trichodesmium and Other Diazotrophs (Carpenter, E.J., Capone, D.G. and Reuter, J.G. Eds.), p. 115-139. Kluwer, Dordrecht.

[7] Fay, P. (1992) Oxygen relations of nitrogen fixation in cyanobacteria. Microbiol. Rev., 56, 340-373.

[8] Gallon, J.R. (1992) Tansley Review No. 44. Reconciling the incompatible: $\mathrm{N}_{2}$ fixation and $\mathrm{O}_{2}$. New Phytol., 122, 571-609.

[9] Huang, T.-C. and Grobbelaar, N. (1995) The circadian clock in the prokaryote Synechococcus RF-1. Microbiol. UK, 141, 535-540.

[10] Bergman, B., Carpenter, E.J., Janson, S., Sroga, G. and Fredriksson, C. (1994) Nitrogenase in the marine non-heterocystous cyanobacterium Trichodesmium. In: Nitrogen Fixation with Non-Legumes (Hegazi, N.A., Fayez, H. and Honib, M. Eds.), p. 85-92. The American University Press, Cairo.

[11] Zehr, J.P. (1995) Nitrogen fixation in the sea: why only Trichodesmium? In: Molecular Biology of Aquatic Microbes (Joint, I. Ed.), p. 335-364. Springer, Berlin.

[12] Gallon, J.R., Jones, D.A. and Page, T.S. (1996) Trichodesmium, the paradoxical diazotroph. Algol. Stud. (Arch. Hydrobiol.), 83/84, (in press).

[13] Stal, L.J. (1995) Tansley Review No. 84. Physiological ecology of cyanobacteria in microbial mats and other communities. New Phytol., 131, 1-32.

[14] Rai, A.N. (1990) Cyanobacteria in Symbiosis. In: Handbook of Symbiotic Cyanobacteria (Rai, A.N. Ed.), p. 1-7. CRC Press, Boca Raton, Florida, U.S.A.

[15] Reynaud, P.A. and Franche, C. (1986) Isolation and characterization of non-heterocystous tropical cyanobacteria growing on nitrogen-free medium. MIRCEN J., 2, 427-443.

[16] Roger, P.A., Voggesberger, M. and Margraf, J. (1986) Nitrogen-fixing phototrophs in the Ifugao rice terraces (Philippines). Philippines Agr., 69, 599-609.
[17] Zhou, H. and Chen, T. (1991) The isolation, purification and efficiency of nitrogen fixation for unicellular cyanobacteria Gloeocapsa spp. Acta Microbiol. Sinica, 31, 405-409.

[18] Rippka, R. and Waterbury, J.B. (1977) The synthesis of nitrogenase by non-heterocystous cyanobacteria. FEMS Microbiol. Lett., 2, 83-86.

[19] Huang, T.-C. and Chow, T.-J. (1988) Comparative studies of some nitrogen-fixing unicellular cyanobacteria isolated from rice fields. J. Gen. Microbiol., 134, 3089-3097.

[20] Gallon, J.R. (1989) The physiology and biochemistry of $\mathrm{N}_{2}$ fixation by non-heterocystous cyanobacteria. Phykos, 28, 1846.

[21] Singh, P.K. (1973) Nitrogen fixation by the unicellular bluegreen alga Aphanothece. Arch. Mikrobiol., 92, 59-62.

[22] Rippka, R., Deruelles, J., Waterbury, J.B., Herdman, M. and Stanier, R.Y. (1979) Generic assignments, strain histories and properties of pure cultures of cyanobacteria. J. Gen. Microbiol., 111, 1-61.

[23] León, C., Kumazawa, S. and Mitsui, A. (1986) Cyclic appearance of aerobic nitrogenase activity during synchronous growth of unicellular cyanobacteria. Current Microbiol., 13, 149-153.

[24] Kallas, T., Coursin, T. and Rippka, R. (1985) Different organisation of nif genes in nonheterocystous and heterocystous cyanobacteria. Plant Mol. Biol., 5, 321-329.

[25] Roger, P.A. (1985) Unicellular mucilagenous blue-green algae (BGA): impressive blooms but deceptive biofertilizers. Int. Rice Res. News, 10, 27-28.

[26] Mitsui, A., Kumazawa, S., Takahashi, A., Ikemoto, H., Cao, S. and Arai, T. (1986) Strategy by which nitrogen-fixing unicellular cyanobacteria grow photoautotrophically. Nature, 323, 720-722.

[27] Spiller, H. and Shanmugam, K.T. (1987) Physiological conditions for nitrogen fixation in a unicellular marine cyanobacterium, Synechococcus sp. strain SF1. J. Bacteriol., 169, 53795384.

[28] Huang, T.-C. and Chow, T.-J. (1986) New type of $\mathrm{N}_{2}$-fixing unicellular cyanobacterium. FEMS Microbiol. Lett., 50, 127130.

[29] Van Ni, C., Khong, D.Z., Tien, Z.D. and Gogotov, I.N. (1988) Nitrogen fixation by the cyanobacterium Aphanothece pallida, isolated from a rice field soil. Mikrobiologiya, 57, 384-388.

[30] Kostyaev, V.Y. (1990) Fixation of molecular nitrogen in aerobic conditions in Aphanothece stagnina cyan alga. IsvestiaAkademiia Nauk SSSR, Seriia Biologicheskaia, 1990, 447449.

[31] Reddy, K.J., Haskell, B., Sherman, D.B. and Sherman, L.A. (1993) Unicellular, aerobic nitrogen-fixing cyanobacteria of the genus Cyanothece. J. Bacteriol., 175, 1284-1292.

[32] Waterbury, J.B., Watson, S.W. and Valois, F.W. (1988) Temporal separation of photosynthesis and dinitrogen fixation in the marine unicellular cyanobacterium Erythrosphaera marina. Eos, 69, 1089.

[33] Ernst, A. (1991) Cyanobacterial picoplankton from Lake Constance. I, Isolation by fluorescence characteristics. J. Plankton Res., 13, 1307-1312. 
[34] Brass, S., Ernst, A. and Böger, P. (1992) Induction and modification of dinitrogenase reductase in the unicellular cyanobacterium Synechocystis BO 8402. Arch. Microbiol., 158, 422428.

[35] Weisshaar, H. and Böger, P. (1983) Nitrogenase activity of the non-heterocystous cyanobacterium Plectonema boryanum. Arch. Microbiol., 136, 270-274.

[36] Jones, K. (1990) Aerobic nitrogen fixation by Lyngbya sp., a marine tropical cyanobacterium. Br. Phycol. J., 25, 287-289.

[37] Paerl, H.W., Prufert, L.E. and Ambrose, W.W. (1991) Contemporaneous $\mathrm{N}_{2}$ fixation and oxygenic photosynthesis in the non-heterocystous mat-forming cyanobacterium Lyngbya aestuarii. Appl. Environ. Microbiol., 57, 3086-3092.

[38] Pearson, H.W., Howsley, R., Kjeldsen, C.K. and Walsby, A.E. (1979) Aerobic nitrogenase activity associated with a non-heterocystous filamentous cyanobacterium. FEMS Microbiol. Lett., 5, 163-167.

[39] Malin, G. and Pearson, H.W. (1988) Aerobic nitrogen fixation in aggregate-forming cultures of the non-heterocystous cyanobacterium Microcoleus chthonoplastes. J. Gen. Microbiol., 134, 1755-1763.

[40] Stal, L.J. and Krumbein, W.E. (1985) Isolation and characterization of cyanobacteria from a marine microbial mat. Bot. Mar., 28, 351-365.

[41] Dubinin, A.V., Zastrizhnaya, O.M. and Gusev, M.V. (1992) Hydrogen-peroxide production by the halophilic cyanobacterium Microcoleus chthonoplastes. Mikrobiologiya, 61, 261-266.

[42] Stal, L.J. and Krumbein, W.E. (1981) Aerobic nitrogen fixation in pure cultures of a benthic marine Oscillatoria (cyanobacteria). FEMS Microbiol. Lett., 11, 295-298.

[43] Kumazawa, S. and Mitsui, A. (1985) Comparative amperometric study of uptake hydrogenase and hydrogen photoproduction activities between heterocystous cyanobacterium Anabaena cylindrica $\mathrm{B} 699$ and nonheterocystous cyanobacterium Oscillatoria sp. strain Miami BG7. Appl. Environ. Microbiol., 50, 287-291.

[44] Khamees, H.S., Gallon, J.R. and Chaplin, A.E. (1987) The pattern of acetylene reduction by cyanobacteria grown under alternating light and darkness. Br. Phycol. J., 22, 55-60.

[45] Phlips, E.J. and Zeman, C. (1990) Photosynthesis, growth and nitrogen-fixation by epiphytic forms of filamentous cyanobacteria from pelagic Sargassum. Bull. Mar. Sci., 47, 613-621.

[46] Gallon, J.R., Hashem, M.A. and Chaplin, A.E. (1991) Nitrogen fixation by Oscillatoria spp. under autotrophic and photoheterotrophic conditions. J. Gen. Microbiol., 137, 31-39.

[47] Bader, K.P. and Röben, A. (1995) Mass-spectrometric detection and analysis of nitrogen fixation in Oscillatoria chalybea. Z. Naturforsch. C, 50, 199-204.

[48] Taylor, B.F., Lee, C.C. and Bunt, J.S. (1973) Nitrogen fixation associated with the marine blue-green alga, Trichodesmium as measured by the acetylene reduction technique. Arch. Mikrobiol., 88, 205-212.

[49] Ohki, K. and Fujita, Y. (1988) Aerobic nitrogenase activity measured as acetylene reduction in the marine non-heterocystous cyanobacterium Trichodesmium spp. grown under artificial conditions. Mar. Biol., 98, 111-114.

[50] Carpenter, E.J., O’Neil, J.M., Dawson, R., Capone, D.G.,
Siddiqui, P.J.A., Roenneberg, T. and Bergman, B. (1993) The tropical diazotrophic phytoplankter Trichodesmium - biological characteristics of two common species. Mar. Ecol. Prog. Ser., 95, 295-304.

[51] Janson, S., Carpenter, E.J. and Bergman, B. (1994) Compartmentalization of nitrogenase in a nonheterocystous cyanobacterium: Trichodesmium contortum. FEMS Microbiol. Lett., 118, 9-14.

[52] Fredriksson, C. and Bergman, B. (1995) Nitrogenase quantity varies diurnally in a subset of cells within colonies of the nonheterocystous cyanobacteria Trichodesmium spp. Microbiol. UK, 141, 2471-2478.

[53] Rippka, R. (1988) Recognition and identification of cyanobacteria. Methods Enzymol., 167, 28-67.

[54] Waterbury, J.B. and Rippka, R. (1989) Subsection I. Order Chroococcales. In: Bergey's Manual of Systematic Bacteriology (Staley, J.T., Bryant, M.P., Pfennig, N. and Holt, J.G. Eds.), p. 1728-1746. Williams and Wilkins, Baltimore.

[55] Waterbury, J.B. (1989) Subsection II. Order Pleurocapsales. In: Bergey's Manual of Systematic Bacteriology (Staley, J.T., Bryant, M.P., Pfennig, N. and Holt, J.G., Eds.), p. 1746-1770. Williams and Wilkins, Baltimore.

[56] Castenholz, R.W. (1989) Subsection III. Order Oscillatoriales. In: Bergey's Manual of Systematic Bacteriology (Staley, J.T., Bryant, M.P., Pfennig, N. and Holt, J.G., Eds.), p. 1771-1780. Williams and Wilkins, Baltimore.

[57] Rippka, R. and Cohen-Bazire, G. (1983) The Cyanobacteriales: a legitimate order based on the type strain Cyanobacterium stanieri? Ann. Microbiol. (Inst. Pasteur), 134B, 21-36.

[58] Kallas, T., Rippka, R., Coursin, T., Rebière, M.-C., Tandeau de Marsac, N. and Cohen-Bazire, G. (1983) Aerobic nitrogen fixation by nonheterocystous cyanobacteria. In: Photosynthetic Prokaryotes (Papageorgiou, G.C. and Packer, L., Eds.), p. 281-302. Elsevier, Amsterdam.

[59] Kallas, T., Rippka, R. and Cohen-Bazire, G. (1984) $\mathrm{H}_{2}$-uptake activity in aerobic nitrogen-fixing nonheterocystous cyanobacteria. In: Advances in Nitrogen Fixation Research (Veeger, C. and Newton, W.E., Eds.), p. 229. Nijhoff/Junk/Pudoc, The Hague and Wageningen.

[60] Du, C. and Gallon, J.R. (1993) Modification of the Fe protein of the nitrogenase of Gloeothece (Nägeli) sp. ATCC 27152 during growth under alternating light and darkness. New Phytol., 125, 121-129.

[61] Prufert-Bebout, L., Paerl, H.W. and Lassen, C. (1993) Growth, nitrogen fixation and spectral attenuation in cultivated Trichodesmium species. Appl. Environ. Microbiol., 59, 1367-1375.

[62] Wilmotte, A. (1994) Molecular evolution and taxonomy of the cyanobacteria. In: The Molecular Biology of Cyanobacteria (Bryant, D.A., Ed.), p. 1-25. Kluwer, Dordrecht.

[63] Rippka, R., Waterbury, J.B. and Cohen-Bazire, G. (1974) A cyanobacterium which lacks thylakoids. Arch. Microbiol., 100, 419-436.

[64] Erokhina, L.G. (1990) Accumulation of phycobiliproteins in cells of free-living nitrogen-fixing cyanobacteria growing on different nitrogen sources. Soviet Plant Physiol., 37, 873-879.

[65] Capone, D.G., O’Neil, J.M., Zehr, J. and Carpenter, E.J. 
(1990) Basis for diel variation in nitrogenase activity in the marine planktonic cyanobacterium Trichodesmium thiebautii. Appl. Environ. Microbiol., 56, 3532-3536.

[66] Carpenter, E.J. and Romans, K. (1991) Major role of the cyanobacterium Trichodesmium in nutrient cycling in the North Atlantic Ocean. Science, 254, 1356-1358.

[67] Carpenter, E.J. and Capone, D.G. (1992) Nitrogen fixation in Trichodesmium blooms. In: Marine Pelagic Cyanobacteria: Trichodesmium and other Diazotrophs (Carpenter, E.J., Capone, D.G. and Rueter, J.G., Eds.), p. 211-217. Kluwer, Dordrecht.

[68] Paerl, H.W. (1994) Spatial segregation of $\mathrm{CO}_{2}$ fixation in Trichodesmium spp: linkage to $\mathrm{N}_{2}$ fixation potential. J. Phycol., 30, 790-799.

[69] Dubinin, A.V., Gerasimenko, L.M. and Zavarzin, G.A. (1992) Nitrogen fixation by cyanobacterium Microcoleus chthonoplastes from hypersaline lagoons of Lake Sivash. Mikrobiologiya, 61, 593-597.

[70] Davis, M.L. (1974) Fixation of Atmospheric Nitrogen in Filamentous Blue-green Algae. PhD thesis, University of Dundee.

[71] Rippka, R. and Stanier, R.Y. (1978) The effects of anaerobiosis on nitrogenase synthesis and heterocyst development by nostocacean cyanobacteria. J. Gen. Microbiol., 105, 83-94.

[72] Spence, D.W. and Stewart, W.D.P. (1987) Heterocystless mutants of Anabaena PCC7120 with nitrogenase activity. FEMS Microbiol. Lett., 40, 119-122.

[73] Ernst, A., Black, T., Cai, Y., Panoff, J.-M., Tiwari, D.N. and Wolk, C.P. (1992) Synthesis of nitrogenase in mutants of the cyanobacterium Anabaena affected in heterocyst development or metabolism. J. Bacteriol., 174, 6025-6032.

[74] Buikema, W.J. and Haselkorn, R. (1993) Molecular genetics of cyanobacterial development. Annu. Rev. Plant Physiol. Plant Mol. Biol., 44, 33-52.

[75] Drum, R.W. and Pankratz, S. (1965) Fine structure of an unusual cytoplasmic inclusion in the diatom genus Rhopalodia. Protoplasma, 60, 141-149.

[76] Floener, L. and Bothe, H. (1980) Nitrogen fixation in Rhopalodia gibba, a diatom containing blue-greenish inclusions symbiotically. In: Endocytobiology, Endosymbiosis and Cell Biology (Schwemmler, W. and Schenk, H.E.K., Eds.), p. 541-552. Walter de Gruyter, Berlin.

[77] Wilkinson, C.R. and Fay, P. (1979) Nitrogen fixation in coral reef sponges with some symbiotic cyanobacteria. Nature, 279, 527-529.

[78] Villareal, T.A. (1992) Marine nitrogen-fixing diatom-cyanobacteria symbioses. In: Marine Pelagic Cyanobacteria: Trichodesmium and other Diazotrophs (Carpenter, E.J., Capone, D.G. and Rueter, J.G., Eds.), Kluwer, Dordrecht.

[79] Rai, A.N. (1990) Cyanobacterial-fungal symbioses: the cyanolichens. In: Handbook of Symbiotic Cyanobacteria (Rai, A.N., Ed.), p. 9-41. CRC Press, Boca Raton, Florida, U.S.A.

[80] Bubrick, P. and Galun, M. (1984) Cyanobiont diversity in the Lichenaceae and Heppiaceae. Lichenologist, 16, 279-287.

[81] Stal, L.J., van Gemerden, H. and Krumbein, W.E. (1985) Structure and development of a benthic marine microbial mat. FEMS Microbiol. Ecol., 31, 111-125.
[82] Potts, M. and Whitton, B.A. (1977) Nitrogen fixation by bluegreen algal communities in the intertidal zone of the lagoon of Aldabra atoll. Oecologia, 27, 275-283.

[83] Potts, M., Krumbein, W.E. and Metzger, J. (1978) Nitrogen fixation rates in anaerobic sediments determined by acetylene reduction, a new ${ }^{15} \mathrm{~N}$ field assay, and simultaneous total $\mathrm{N}^{15} \mathrm{~N}$ determination. In: Environmental Biogeochemistry and Geomicrobiology, 3, Methods, Metals and Assessment (Krumbein, W.E., Ed.), p. 753-769. Ann Arbor Science, Ann Arbor.

[84] Gotto, J.W., Tabita, F.R. and Van Baalen, C. (1981) Nitrogen fixation in intertidal environments of the Texas Gulf Coast. Estuar. Coast. Shelf Sci., 12, 231-235.

[85] Bautista, M.F. and Paerl, H.W. (1985) Diel $\mathrm{N}_{2}$ fixation in an intertidal marine cyanobacterial community. Mar. Chem., 16, 369-377.

[86] Skyring, G.W., Lynch, R.M. and Smith, G.D. (1988) Acetylene reduction and hydrogen metabolism by a cyanobacterial/ sulfate-reducing bacterial mat ecosystem. Geomicrobiol. J., 6, 25-31.

[87] Paling, E.I., McComb, A.J. and Pate, J.S. (1989) Nitrogen fixation (acetylene reduction) in nonheterocystous cyanobacterial mats from the Dampier Archipelago, Western Australia. Aust. J. Mar. Freshwater Res., 40, 147-153.

[88] Stal, L.J., Grossberger, S. and Krumbein, W.E. (1984) Nitrogen fixation associated with the cyanobacterial mat of a marine laminated microbial ecosystem. Mar. Biol., 82, 217-224.

[89] Bebout, B.M., Paerl, H.W., Crocker, K.M. and Prufert, L.E. (1987) Diel interactions of oxygenic photosynthesis and $\mathrm{N}_{2}$ fixation (acetylene reduction) in a microbial mat community. Appl. Environ. Microbiol., 53, 2353-2362.

[90] Javor, B.J. and Castenholz, R.W. (1981) Laminated microbial mats, Laguna Guerrero, Mexico. Geomicrobiol. J., 2, 237273.

[91] Renaut, J., Sasson, A., Pearson, H.W. and Stewart, W.D.P. (1975) Nitrogen-fixing algae in Morocco. In: Nitrogen Fixation by Free-living Microorganisms (Stewart, W.D.P., Ed.), p. 229-246. Cambridge University Press, Cambridge.

[92] Griffiths, M.S.H., Gallon, J.R. and Chaplin, A.E. (1987) The diurnal pattern of dinitrogen fixation by cyanobacteria in situ. New Phytol., 107, 649-657.

[93] Jones, K. (1992) Diurnal nitrogen fixation in tropical marine cyanobacteria: a comparison between adjacent communities of non-heterocystous Lyngbya sp. and heterocystous Calothrix sp. Br. Phycol. J., 27, 107-118.

[94] Smith, G.D., Lynch, R.M., Jacobson, G. and Barnes, C.J. (1990) Cyanobacterial nitrogen fixation in arid soils of Central Australia. FEMS Microbiol. Ecol., 74, 79-89.

[95] Roger, P.A., Santiago-Ardales, S. and Watanabe, I. (1986) Nitrogen fixing blue-green algae in rice soils of Northern Luzon (Philippines). Philippines Agr., 69, 589-598.

[96] Desikachary, T.V. (1959) Cyanophyta. 686 pp. Indian Council of Agricultural Research, New Delhi.

[97] Ernst, A., Sandmann, G., Postius, C., Brass, S., Kenter, U. and Böger, P. (1992) Cyanobacterial picoplankton from Lake Constance. 2. Classification of isolates by cell morphology and pigment composition. Bot. Acta, 105, 161-167.

[98] Pandey, K.D., Kashyap, A.K. and Gupta, R.K. (1992) Nitro- 
gen-fixation by cyanobacteria associated with moss communities in Schirmacher oasis, Antarctica. Israel J. Bot., 41, 187198.

[99] Duerr, E.O. and Mitsui, A. (1980) Aerobic growth and nitrogenase activity of a marine unicellular blue-green alga, Synechococcus sp. Plant Physiol., 65 (suppl), 160.

[100] Dupouy, C., Petit, M. and Dandonneau, Y. (1988) Satellite detected cyanobacteria bloom in the southwestern tropical Pacific. Implication for oceanic nitrogen fixation. Int. J. Remote Sensing, 9, 389-396.

[101] Marumo, R. and Asaoka, O. (1974) Trichodesmium in the East China Sea. 1. Distribution of Trichodesmium thiebauti Gomont during 1961-1967. J. Oceanogr. Soc. Japan, 30, 48 53.

[102] Marumo, R. and Nagasawa, S. (1976) Seasonal variation of the standing crop of the pelagic blue-green alga, Trichodesmium in the Kuroshio water. Bull. Plankt. Soc. Japan, 23, $19-25$.

[103] Janson, S., Siddiqui, P.J.A., Walsby, A.E., Romans, K.M., Carpenter, E.J. and Bergman, B. (1995) Cytomorphological characterization of the planktonic diazotrophic cyanobacteria Trichodesmium spp. from the Indian Ocean, Caribbean and Sargasso Seas. J. Phycol., 31, 463-477.

[104] Ohki, K. and Fujita, Y. (1982) Laboratory culture of the pelagic blue-green alga Trichodesmium thiebautii: conditions for unialgal culture. Mar. Ecol. Prog. Ser., 7, 185-190.

[105] Paerl, H.W., Bebout, B.M. and Prufert, L.E. (1989) Bacterial associations with marine Oscillatoria sp. (Trichodesmium sp.) populations: ecophysiological implications. J. Phycol., 25, 773-784.

[106] Siddiqui, P.J.A., Bergman, B. and Carpenter, E.J. (1992) Filamentous cyanobacterial associates of the marine planktonic cyanobacterium Trichodesmium. Phycologia, 31, 326 337.

[107] Bergman, B. and Carpenter, E.J. (1991) Nitrogenase confined to randomly distributed trichomes in the marine cyanobacterium Trichodesmium. J. Phycol., 27, 158-165.

[108] Howarth, R.W., R., M., Lane, J. and Cole, J.J. (1988) Nitrogen fixation in freshwater, estuarine and marine ecosystems. 1. Rates and importance. Limnol. Oceanog., 33, 669 687.

[109] Karl, D.M., Letelier, R., Hebel, D.V., Bird, D.F. and Winn, C.D. (1992) Trichodesmium blooms and new nitrogen in the North Pacific gyre. In: Marine Pelagic Cyanobacteria: Trichodesmium and other Diazotrophs (Carpenter, E.J., Capone, D.G. and Rueter, J.G., Eds.), p. 219-237. Kluwer, Dordrecht.

[110] Capone, D.G. and Carpenter, E.J. (1982) Nitrogen fixation in the marine environment. Science, 217, 1140-1142.

[111] Paul, E.A. (1978) Contribution of nitrogen fixation to ecosystem functioning and nitrogen fluxes on a global basis. Ecol. Bull. (Stockholm), 26, 282-293.

[112] Burns, R.C. and Hardy, R.W.F. (1975) Nitrogen Fixation in Bacteria and Higher Plants. 189 pp. Springer, Berlin.

[113] Letelier, R.M. and Karl, D.M. (1996) Role of Trichodesmium spp. in the productivity of the subtropical North Pacific Ocean. Mar. Ecol. Prog. Ser., 133, 263-273.
[114] Villbrandt, M., Stal, L.J. and Krumbein, W.E. (1990) Interactions between nitrogen fixation and oxygenic photosynthesis in a marine cyanobacterial mat. FEMS Microbiol. Ecol., 74, 59-72.

[115] Pau, R. (1991) The alternative nitrogenases. In: Biology and Biochemistry of Nitrogen Fixation (Dilworth, M.J. and Glenn, A.R., Eds.), p. 37-57. Elsevier, Amsterdam.

[116] Smith, B.E. and Eady, R.R. (1992) Metalloclusters of the nitrogenases. Eur. J. Biochem., 205, 1-15.

[117] Kentemich, T., Danneberg, G., Hundeshagen, B. and Bothe, H. (1988) Evidence for the occurrence of the alternative vanadium-containing nitrogenase in the cyanobacterium Anabaena variabilis. FEMS Microbiol. Lett., 51, 19-24.

[118] Gallon, J.R. and Chaplin, A.E. (1988) Nitrogen fixation. In: The Biochemistry of Algae and Cyanobacteria (Rogers, L.J. and Gallon, J.R., Eds.), p. 147-173. Oxford University Press, Oxford.

[119] Bothe, H., Kentemich, T. and Heping, D. (1991) Recent aspects on the hydrogenase-nitrogenase relationship in cyanobacteria. In: Nitrogen Fixation (Polsinelli, M., Materassi, R. and Vincenzini, M., Eds.), p. 367-375. Kluwer, Dordrecht.

[120] Thiel, T. (1993) Characterization of genes for an alternative nitrogenase in cyanobacterium Anabaena variabilis. J. Bacteriol., 175, 6276-6286.

[121] Maryan, P.S., Eady, R.R., Chaplin, A.E. and Gallon, J.R. (1986) Nitrogen fixation by the unicellular cyanobacterium Gloeothece. Nitrogenase synthesis is only transiently repressed by $\mathrm{O}_{2}$. FEMS Microbiol. Lett., 34, 251-255.

[122] Paerl, H.W., Priscu, J.C. and Brawner, D.L. (1989) Immunochemical localization of nitrogenase in marine Trichodesmium aggregates: relationship to $\mathrm{N}_{2}$ fixation potential. Appl. Environ. Microbiol., 55, 2965-2975.

[123] Smoker, J.A., Owen, H.A. and Lehnen, L.P., Jr. (1989) Ultrastructure of the nitrogen-fixing, filamentous, nonheterocystous cyanobacterium, Plectonema boryanum. Protoplasma, 152, 130-135.

[124] Stal, L.J. and Bergman, B. (1990) Immunological characterization of nitrogenase in the filamentous cyanobacterium $\mathrm{Os}^{-}$ cillatoria limosa. Planta, 182, 287-291.

[125] Zehr, J.P., Limberger, R.J., Ohki, K. and Fujita, Y. (1990) Antiserum to nitrogenase generated from an amplified DNA fragment from natural populations of Trichodesmium spp. Appl. Environ. Microbiol., 56, 3227-3531.

[126] Rai, A.N., Borthakur, M. and Bergman, B. (1992) Nitrogenase derepression, its regulation and metabolic changes associated with diazotrophy in the non-heterocystous cyanobacterium Plectonema boryanum PCC 73110. J. Gen. Microbiol., 138, 481-491.

[127] Nagatani, H.H. and Haselkorn, R. (1978) Molybdenum independence of nitrogenase component synthesis in the nonheterocystous cyanobacterium Plectonema. J. Bacteriol., 134, 597-605.

[128] Hallenbeck, P.C., Kostel, P.J. and Benemann, J.R. (1979) Purification and properties of nitrogenase from the cyanobacterium Anabaena cylindrica. Eur. J. Biochem., 98, 275284 . 
[129] Braun-Howland, E.B., Lindblad, P., Nierzwicki-Bauer, S.A. and Bergman, B. (1988) Dinitrogenase reductase (Fe-protein) of nitrogenase in the cyanobacterial symbionts of three Azolla species: localization and sequence of appearance during heterocyst differentiation. Planta, 176, 319-333.

[130] Bergman, B. and Rai, A.N. (1989) The Nostoc-Nephroma symbiosis: localization, distribution pattern and levels of key proteins involved in nitrogen and carbon metabolism of the cyanobiont. Physiol. Plantarum, 77, 216-224.

[131] Renström-Kellner, E., Rai, A.N. and Bergman, B. (1990) Correlation between nitrogenase and glutamine synthetase expression in the cyanobacterium Anabaena cylindrica. Physiol. Plantarum, 80, 12-19.

[132] Zehr, J.P., Wyman, M., Miller, V., Duguay, L. and Capone, D.G. (1993) Modification of the Fe protein of nitrogenase in natural populations of Trichodesmium thiebautii. Appl. Environ. Microbiol., 59, 669-676.

[133] Chow, T.J. and Tabita, F.R. (1994) Reciprocal light-dark transcriptional control of nif and $r b c$ expression and lightdependent posttranslational control of nitrogenase activity in Synechococcus sp strain RF-1. J. Bacteriol., 176, 6281-6285.

[134] Ohki, K., Zehr, J.P., Falkowski, P.G. and Fujita, Y. (1991) Regulation of nitrogen fixation by different sources in the marine non-heterocystous cyanobacterium Trichodesmium sp. NIBB 1067. Arch. Microbiol., 156, 335-337.

[135] Ludden, P.W. and Roberts, G.P. (1989) Regulation of nitrogenase by reversible ADP-ribosylation. Curr. Top. Cell. Regul., 30, 23-56.

[136] Nordlund, S. (1991) Metabolic regulation of nitrogen fixation in anoxygenic photosynthetic bacteria. In: Nitrogen Fixation (Polsinelli, M., Materassi, R. and Vincenzini, M., Eds.), p. 491-502. Kluwer, Dordrecht.

[137] Roberts, G.P. and Ludden, P.W. (1992) Nitrogen fixation by photosynthetic bacteria. In: Biological Nitrogen Fixation (Stacey, G., Burris, R.H. and Evans, H.J., Eds.), p. 135165. Chapman and Hall, New York.

[138] Zhang, Y.P., Grunwald, S.K., Lies, D., Halbleib, C., Ma, Y., Roberts, G.P., Burris, R.H. and Ludden, P.W. (1995) Posttranslational regulation of nitrogenase activity by reversible ADP-ribosylation; how are the regulatory enzymes DRAT and DRAG regulated? In: Nitrogen Fixation: Fundamentals and Applications (Tikhonovich, I.A., Provorov, N.A., Romanov, V.I. and Newton, W.E., Eds.), p. 177-182. Kluwer, Dordrecht.

[139] Ohki, A., Zehr, J.P. and Fujita, Y. (1992) Regulation of nitrogenase activity in relation to the light-dark regime in the filamentous non-heterocystous cyanobacterium Trichodesmium sp. NIBB 1067. J. Gen. Microbiol., 138, 26792685.

[140] Reich, S. and Böger, P. (1989) Regulation of nitrogenase activity in Anabaena variabilis by modification of the Fe protein. FEMS Microbiol. Lett., 58, 81-86.

[141] Ernst, A., Liu, Y.-D., Reich, S. and Böger, P. (1990) Diurnal nitrogenase modification in the cyanobacterium Anabaena variabilis. Bot. Acta, 103, 183-189.

[142] Böhm, I., Halbherr, A., Smaglinski, S., Ernst, A. and Böger, P. (1992) In vitro activation of dinitrogenase reductase from the cyanobacterium Anabaena variabilis (ATCC 29413). J. Bacteriol., 174, 6179-6183.

[143] Durner, J., Böhm, I., Hilz, H. and Böger, P. (1994) Posttranslational modification of nitrogenase. Differences between the purple bacterium Rhodospirillum rubrum and the cyanobacterium Anabaena variabilis. Eur. J. Biochem., 220, 125-130.

[144] Du, C., Reade, J.P.H., Rogers, L.J. and Gallon, J.R. (1994) Dinitrogenase reductase ADP-ribosyl transferase and dinitrogenase reductase activating glycohydrolase in Gloeothece. Biochem. Soc. Trans., 22, 332S.

[145] Silman, N.J., Carr, N.G. and Mann, N.H. (1995) ADP-ribosylation of glutamine synthetase in the cyanobacterium $S y$ nechocystis sp strain PCC 6803. J. Bacteriol., 177, 3527-3533.

[146] Kallas, T., Rebière, M.-C., Rippka, R. and Tandeau de Marsac, N. (1983) The structural nif genes of the cyanobacteria Gloeothece sp. and Calothrix share homology with those of Anabaena sp., but the Gloeothece genes have a different arrangement. J. Bacteriol., 155, 427-431.

[147] Ben-Porath, J. and Zehr, J.P. (1994) Detection and characterization of cyanobacterial nifH genes. Appl. Environ. Microbiol., 60, 880-887.

[148] Barnum, S.R. and Gendel, S.M. (1985) Organization of nitrogen fixation genes in a nonheterocystous, filamentous cyanobacterium. FEMS Microbiol. Lett., 29, 339-342.

[149] Apte, S.K. and Thomas, J. (1987) Nitrogen fixation genes (nifK, $D, H$ ) in the filamentous nonheterocystous cyanobacterium Plectonema boryanum do not rearrange. J. Genet., 66, 101-110.

[150] Smoker, J.A. and Barnum, S.R. (1988) Analysis of nifK, D, $H$ genes and their expression in the cyanobacterium Plectonema boryanum. In: Nitrogen Fixation: Hundred Years After (Bothe, H., de Bruijn, F.J. and Newton, W.E., Eds.), p. 217. Fischer, Stuttgart.

[151] Saville, B., Straus, N. and Coleman, J.R. (1987) Contiguous organization of nitrogenase genes in a heterocystous cyanobacterium. Plant Physiol., 85, 26-29.

[152] Singh, R.K., Stevens, S.E., Jr. and Bryant, D.A. (1987) Molecular cloning and physical mapping of the nitrogenase structural genes from the filamentous, non-heterocystous cyanobacterium Pseudanabaena sp. PCC 7409. FEMS Microbiol. Lett., 48, 53-58.

[153] Zehr, J.P., Ohki, K. and Fujita, Y. (1991) Arrangement of nitrogenase structural genes in an aerobic filamentous cyanobacterium. J. Bacteriol., 173, 7055-7058.

[154] Huang, T.-C., Chow, T.-J. and Hwang, I.-S. (1988) The cyclic synthesis of the nitrogenase of Synechococcus RF-1 and its control at the transcription level. FEMS Microbiol. Lett., $50,127-130$.

[155] Huang, T.-C. and Chow, T.-J. (1990) Characterization of the rhythmic nitrogen-fixing activity of Synechococcus sp. RF-1 at the transcription level. Current Microbiol., 20, 23-26.

[156] Zehr, J.P. and McReynolds, L.A. (1989) Use of degenerate oligonucleotides for amplification of the nifH gene from the marine cyanobacterium Trichodesmium thiebautii. Appl. Environ. Microbiol., 55, 2522-2526.

[157] Sroga, G.E., Landegren, U., Bergman, B. and Lagerström- 
Fermér, M. (1996) Isolation of nifH and part of nifD by modified capture polymerase chain reaction from a natural population of the marine cyanobacterium Trichodesmium sp. FEMS Microbiol. Lett., 136, 137-145.

[158] Fujita, Y., Takahashi, Y., Shonai, F., Ogura, Y. and Matsubara, H. (1991) Cloning, nucleotide sequences and differential expression of the nif $H$ and nif $H$-like $(f r x C)$ genes from the filamentous nitrogen-fixing cyanobacterium Plectonema boryanum. Plant Cell Physiol., 32, 1093-1106.

[159] Golden, J.W., Robinson, S.J. and Haselkorn, R. (1985) Rearrangement of nitrogen fixation genes during heterocyst differentiation in the cyanobacterium Anabaena. Nature, 314, 419-423.

[160] Haselkorn, R. (1992) Developmentally regulated gene rearrangements in prokaryotes. Annu. Rev. Genet., 26, 113130.

[161] Fujita, Y., Takahashi, Y., Chuganji, M. and Matsubara, H. (1992) The nifH-like ( $f r x C$ ) gene is involved in the biosynthesis of chlorophyll in the filamentous cyanobacterium Plectonema boryanum. Plant Cell Physiol., 33, 81-92.

[162] Fujita, Y., Matsumoto, H., Takahashi, Y. and Matsubara, H. (1993) Identification of a nifDK-like gene (ORF467) involved in the biosynthesis of chlorophyll in the cyanobacterium Plectonema boryanum. Plant Cell Physiol., 34, 305-314.

[163] Lowe, D.J. and Thorneley, R.N.F. (1984) The mechanism of Klebsiella pneumoniae nitrogenase action. Pre-steady-state kinetics of $\mathrm{H}_{2}$ formation. Biochem. J., 224, 877-886.

[164] Gallon, J.R. and Chaplin, A.E. (1987) An Introduction to Nitrogen Fixation. 276 pp. Cassell, Eastbourne.

[165] Smith, R.J. and Gallon, J.R. (1993) Nitrogen fixation. In: Plant Biochemistry and Molecular Biology (Lea, P.J. and Leegood, R.C., Eds.), p. 129-153. Wiley, Chichester.

[166] Kim, J. and Rees, D.C. (1992) Crystallographic structure and functional implications of the nitrogenase molybdenum-iron protein from Azotobacter vinelandii. Nature, 360, 553-560.

[167] Kim, J. and Rees, D.C. (1994) Nitrogenase and biological nitrogen fixation. Biochemistry, 33, 389-397.

[168] Hill, S. and Kavanagh, E.P. (1994) Autoregulation of nitrogenase expression in Klebsiella pneumoniae. Microbiol. UK, 140, 1917-1925.

[169] Weare, N.M. and Benemann, J.R. (1974) Nitrogenase activity and photosynthesis in Plectonema boryanum. J. Bacteriol., 119, 258-265.

[170] Giani, D. and Krumbein, W.E. (1986) Growth characteristics of non-heterocystous cyanobacterium Plectonema boryanum with $\mathrm{N}_{2}$ as nitrogen source. Arch. Microbiol., 145, 259-265.

[171] Almon, H. and Böger, P. (1988) Nitrogen and hydrogen metabolism: induction and measurements. Methods Enzymol., 167, 459-467.

[172] Rogerson, A.C. (1980) Nitrogen-fixing growth by non-heterocystous cyanobacterium Plectonema boryanum. Nature, 284, 563-564.

[173] Smoker, J.A. and Barnum, S.R. (1990) Nitrogen fixation activity of a filamentous, nonheterocystous cyanobacterium in the presence and absence of exogenous, organic substrates. Arch. Microbiol., 153, 417-421.

[174] Magasanik, B. (1988) Reversible phosphorylation of an en- hancer binding protein regulates the transcription of bacterial nitrogen utilization genes. Trends Biochem. Sci., 13, 475479.

[175] Tsinoremas, N.F., Castets, A.M., Harrison, M.A., Allen, J.F. and Tandeau de Marsac, N. (1991) Photosynthetic electron transport controls nitrogen assimilation in cyanobacteria by means of post-translational modification of the $\operatorname{gln} B$ gene product. Proc. Natl. Acad. Sci. USA, 88, 4565-4569.

[176] Forchhammer, K. and Tandeau de Marsac, N. (1994) The $\mathrm{P}_{\mathrm{II}}$ protein in the cyanobacterium Synechococcus sp. strain PCC 7942 is modified by serine phosphorylation and signals the cellular N-status. J. Bacteriol., 176, 84-91.

[177] Vega-Palas, M.A., Flores, E. and Herrero, A. (1992) NtcA, a global nitrogen regulator from the cyanobacterium Synechococcus that belongs to the Crp family of bacterial regulators. Molec. Microbiol., 6, 1853-1859.

[178] Frías, J.E., Merida, A., Herrero, A., Martinnieto, J. and Flores, E. (1993) General distribution of the nitrogen control gene $n t c A$ in cyanobacteria. J. Bacteriol., 175, 5710-5713.

[179] Wei, T.F., Ramasubramanian, T.S., Pu, F. and Golden, J.W. (1993) Anabaena sp strain PCC 7120 bif A gene encoding a sequence-specific DNA-binding protein cloned by in vivo transcriptional interference selection. J. Bacteriol., 175, 4025-4035.

[180] Flores, E. and Herrero, A. (1994) Assimilatory nitrogen metabolism and its regulation. In: The Molecular Biology of Cyanobacteria (Bryant, D.A., Ed.), p. 487-547. Kluwer, Dordrecht.

[181] Luque, I., Flores, E. and Herrero, A. (1994) Molecular mechanism for the operation of nitrogen control in cyanobacteria. EMBO J., 13, 2862-2869.

[182] Jiang, F.Y., Hellman, U., Sroga, G.E., Bergman, B. and Mannervik, B. (1995) Cloning, sequencing and regulation of the glutathione-reductase gene from the cyanobacterium Anabaena PCC-7120. J. Biol. Chem., 270, 22882-22889.

[183] Lilley, D.M.J. (1991) When the CAP fits bent DNA. Nature, 354, 359-360.

[184] Frías, J.E., Flores, E. and Herrero, A. (1994) Requirement of the regulatory protein $n t c A$ for the expression of nitrogen assimilation and heterocyst development genes in the cyanobacterium Anabaena sp PCC 7120. Molec. Microbiol., 14, 823-832.

[185] Wei, T.F., Ramasubramanian, T.S. and Golden, J.W. (1994) Anabaena sp strain PCC 7120 ntc $A$ gene required for growth on nitrate and heterocyst development. J. Bacteriol., 176, 4473-4482.

[186] Fay, P., Stewart, W.D.P., Walsby, A.E. and Fogg, G.E. (1968) Is the heterocyst the site of nitrogen fixation in blue-green algae? Nature, 220, 810-812.

[187] Gallon, J.R. (1980) Nitrogen fixation by photoautotrophs. In: Nitrogen Fixation (Stewart, W.D.P. and Gallon, J.R., Eds.), p. 197-238. Academic Press, London.

[188] Murry, M.A., Hallenbeck, P.C. and Benemann, J.R. (1984) Immunochemical evidence that nitrogenase is restricted to heterocysts in Anabaena cylindrica. Arch. Microbiol., 137, 194-195.

[189] Bergman, B., Lindblad, P. and Rai, A.N. (1986) Nitrogenase 
in free-living and symbiotic cyanobacteria: immunoelectronmicroscopic localization. FEMS Microbiol. Lett., 35, 7578 .

[190] Elhai, J. and Wolk, C.P. (1990) Developmental regulation and spatial pattern of expression of the structural genes for nitrogenase in the cyanobacterium Anabaena. EMBO J., 9, 3379-3388.

[191] Thiel, T., Lyons, E.M., Erker, J.C. and Ernst, A. (1995) A second nitrogenase in vegetative cells of a heterocyst-forming cyanobacterium. Proc. Natl. Acad. Sci. USA, 92, 9358-9362.

[192] Schrautemeier, B., Neveling, U. and Schmitz, S. (1995) Distinct and differently regulated Mo-dependent nitrogen-fixing systems evolved for heterocysts and vegetative cells of Anabaena variabilis ATCC 2941: characterization of the $f d x H 1 / 2$ gene regions as part of the nif1/2 gene clusters. Molec. Microbiol., 18, 357-369.

[193] Stewart, W.D.P. (1980) Some aspects of structure and function in $\mathrm{N}_{2}$-fixing cyanobacteria. Annu. Rev. Microbiol., 34, 497-536.

[194] Meeks, J.C., Wolk, C.P., Lockau, W., Schilling, N., Schaffer, P.W. and Chien, W.-S. (1978) Pathways of assimilation of $\left({ }^{13} \mathrm{~N}\right) \mathrm{N}_{2}$ and ${ }^{13} \mathrm{NH}_{4}{ }^{+}$by cyanobacteria with and without heterocysts. J. Bacteriol., 134, 125-130.

[195] Gallon, J.R. and Hamadi, A.F. (1984) Studies on the effects of oxygen on acetylene reduction (nitrogen fixation) in Gloeothece sp. ATCC 27152. J. Gen. Microbiol., 130, 495503.

[196] Maryan, P.S., Eady, R.R., Chaplin, A.E. and Gallon, J.R. (1986) Nitrogen fixation by Gloeothece sp. PCC 6909: respiration and not photosynthesis supports nitrogenase activity in the light. J. Gen. Microbiol., 132, 789-796.

[197] Carpenter, E.J. and Price, C.C. (1976) Marine Oscillatoria (Trichodesmium): explanation for aerobic nitrogen fixation without heterocysts. Science, 191, 1278-1280.

[198] Bryceson, I. and Fay, P. (1981) Nitrogen fixation in Oscillatoria (Trichodesmium) erythreae in relation to bundle formation and trichome differentiation. Mar. Biol., 61, 159-166.

[199] Carpenter, E.J., Chang, J., Cottrell, M., Schubauer, J., Paerl, H.W., Bebout, B.M. and Capone, D.G. (1990) Re-evaluation of nitrogenase oxygen-protective mechanisms in the planktonic marine cyanobacterium Trichodesmium. Mar. Ecol. Prog. Ser., 65, 151-158.

[200] Siddiqui, P.J.A., Carpenter, E.J. and Bergman, B. (1992) Ultrastructure and immunolocalization of phycobiliproteins and ribulose 1,5-bisphosphate carboxylase/oxygenase in the marine cyanobacterium Trichodesmium thiebautii. J. Phycol., 28, 320-327.

[201] Paerl, H.W., Pinckney, J.L. and Kucera, S.A. (1995) Clarification of the structural and functional roles of heterocysts and anoxic microzones in the control of pelagic nitrogen fixation. Limnol. Oceanog., 40, 634-638.

[202] Grobbelaar, N., Chou, W.-M. and Huang, T.-C. (1992) Effect of $\mathrm{CO}_{2}, \mathrm{O}_{2}, \mathrm{DCMU}, \mathrm{FCCP}$, and DL-glyceraldehyde on the nitrogenase activity of Synechococcus RF-1. Bot. Bull. Acad. Sinica, 33, 167-174.

[203] van der Oost, J., Kanneworff, W.A., Krab, K. and Kraayenhof, R. (1987) Hydrogen metabolism in three unicellular ni- trogen-fixing cyanobacteria. FEMS Microbiol. Rev., 48, 4145 .

[204] Stal, L.J., Myint, K.S. and Ortega-Calvo, J.J. (1991) Photosynthesis and nitrogen fixation in the unicellular cyanobacterium Gloeothece PCC 6909. In: Nitrogen Fixation (Polsinelli, M., Materassi, R. and Vincenzini, M., Eds.), p. 437 442. Kluwer, Dordrecht.

[205] Wolk, C.P. (1982) Heterocysts. In: The Biology of Cyanobacteria (Carr, N.G. and Whitton, B.A., Eds.), p. 359-386. Blackwell, Oxford.

[206] Wolk, C.P., Ernst, A. and Elhai, J. (1994) Heterocyst metabolism and development. In: The Molecular Biology of Cyanobacteria (Bryant, D.A., Ed.), p. 769-823. Kluwer, Dordrecht.

[207] Kumar, A.P., Rai, A.N. and Singh, H.N. (1985) Nitrate reductase activity in isolated heterocysts of the cyanobacterium Nostoc muscorum. FEBS Lett., 179, 125-128.

[208] Rai, A.N. and Bergman, B. (1986) Modification of $\mathrm{NO}_{3}{ }^{-}$ metabolism in heterocysts of the $\mathrm{N}_{2}$-fixing cyanobacterium Anabaena 7120 (ATCC 27893). FEMS Microbiol. Lett., 36, 133-137.

[209] Peschek, G.A., Villgrater, K. and Wastyn, M. (1991) 'Respiratory protection' of the nitrogenase in dinitrogen-fixing cyanobacteria. Plant Soil, 137, 17-24.

[210] Gallon, J.R., Perry, S.M., Rajab, T.M.A., Flayeh, K.A.M., Yunes, J.S. and Chaplin, A.E. (1988) Metabolic changes associated with the diurnal pattern of $\mathrm{N}_{2}$ fixation in Gloeothece. J. Gen. Microbiol., 134, 3079-3087.

[211] Grobbelaar, N., Li, W.-T. and Huang, T.-C. (1991) Relationship between the nitrogenase activity and dark respiration rate of Synechococcus RF-1. FEMS Microbiol. Lett., 83, 99-102.

[212] Bergman, B., Siddiqui, P.J.A., Carpenter, E.J. and Peschek, G.A. (1993) Cytochrome oxidase: subcellular distribution and relationship to nitrogenase expression in the nonheterocystous marine cyanobacterium Trichodesmium thiebautii. Appl. Environ. Microbiol., 59, 3239-3244.

[213] Carpenter, E.J., Bergman, B., Dawson, R., Siddiqui, P.J.A., Söderbäck, E. and Capone, D.G. (1992) Glutamine synthetase and nitrogen cycling in colonies of the marine diazotrophic cyanobacterium Trichodesmium spp. Appl. Environ. Microbiol., 58, 3122-3129.

[214] Cheng, J., Hipkin, C.R. and Gallon, J.R. (1995) Interactions between $\mathrm{N}_{2}$ fixation and alternative nitrogen sources in Gloeothece. In: Nitrogen Fixation: Fundamentals and Applications (Tikhonovich, I.A., Provorov, N.A., Romanov, V.I. and Newton, W.E., Eds.), p. 228. Kluwer, Dordrecht.

[215] Thomas, J.H., Mullineaux, P.M., Cronshaw, A.D., Chaplin, A.E. and Gallon, J.R. (1982) The effects of structural analogues of amino acids on $\mathrm{NH}_{4}{ }^{+}$-assimilation and acetylene reduction (nitrogen fixation) in Gloeocapsa (Gloeothece) sp. CCAP 1430/3. J. Gen. Microbiol., 128, 885-893.

[216] Mitsui, A. and Suda, S. (1995) Alternative and cyclic appearance of $\mathrm{H}_{2}$ and $\mathrm{O}_{2}$ photoproduction activities under nongrowing conditions in an aerobic nitrogen-fixing unicellular cyanobacterium Synechococcus sp. Current Microbiol., 30, 1-6. 
[217] Pearson, H.W. and Howsley, R. (1980) Concomitant photoautotrophic growth and nitrogenase activity by the cyanobacterium Plectonema boryanum in continuous culture. Nature, 288, 263-265.

[218] Misra, H.S. and Tuli, R. (1993) Photosystem-II independent carbon-dioxide fixation in Plectonema boryanum during photoautotrophic growth under nitrogen-fixation conditions. J. Plant Biochem. Biotechnol., 2, 101-104.

[219] Misra, H.S. and Tuli, R. (1994) Nitrogen fixation by Plectonema boryanum: a photosystem-II independent component. Microbiol. UK, 140, 971-976.

[220] Misra, H.S. and Tuli, R. (1994) Uncoupling of photosystems during light-dependent dinitrogen fixation by a nonheterocystous cyanobacterium Plectonema boryanum. Indian J. Biochem. Biophys. 31, 310-314.

[221] Schneegurt, M.A., Sherman, D.M., Nayar, S. and Sherman, L.A. (1994) Oscillating behavior of carbohydrate granule formation and dinitrogen fixation in the cyanobacterium $C y$ anothece sp strain ATCC 51142. J. Bacteriol., 176, 15861597.

[222] Villbrandt, M., Stal, L.J., Bergman, B. and Krumbein, W.E. (1992) Immunolocalization and western blot analysis of nitrogenase in Oscillatoria limosa during a light-dark cycle. Bot. Acta, 105, 90-96.

[223] Stal, L.J. and Krumbein, W.E. (1985) Nitrogenase activity in the non-heterocystous cyanobacterium Oscillatoria sp. grown under alternating light-dark cycles. Arch. Microbiol., 143, $67-71$.

[224] Gallon, J.R., Reade, J.P.H., Dougherty, L.J., Pederson, D.M. and Rogers, L.J. (1995) Degradation of nitrogenase in Gloeothece. In: Nitrogen Fixation: Fundamentals and Applications (Tikhonovich, I.A., Provorov, N.A., Romanov, V.I. and Newton, W.E., Eds.), p. 230. Kluwer, Dordrecht.

[225] Durner, J., I., B., Knörzer, O.C. and Böger, P. (1996) Proteolytic degradation of dinitrogenase reductase from Anabaena variabilis (ATCC 29413) as a consequence of ATP depletion and impact of oxygen. J. Bacteriol., 178, 606-610.

[226] Ortega-Calvo, J.-J. and Stal, L.J. (1991) Diazotrophic growth of the unicellular cyanobacterium Gloeothece sp. PCC 6909 in continuous culture. J. Gen. Microbiol., 137, 1789-1797.

[227] Ortega-Calvo, J.J. and Stal, L.J. (1994) Sulfate-limited growth in the $\mathrm{N}_{2}$-fixing unicellular cyanobacterium Gloeothece (Nägeli) sp PCC 6909. New Phytol., 128, 273281.

[228] Ikemoto, H. and Mitsui, A. (1994) Diazotrophic synchronous growth of a marine unicellular cyanobacterium, Synechococcus sp strain Miami BG 043511, under aerobic and microaerobic/anaerobic conditions. Microbiol. UK, 140, 2153-2158.

[229] Stal, L.J. and Heyer, H. (1987) Dark anaerobic nitrogen fixation (acetylene reduction) in the cyanobacterium Oscillatoria. FEMS Microbiol. Ecol., 45, 227-232.

[230] Heyer, H., Stal, L.J. and Krumbein, W.E. (1989) Simultaneous heterolactic and acetate fermentation in the marine cyanobacterium Oscillatoria limosa incubated anaerobically in the dark. Arch. Microbiol., 151, 558-564.

[231] Paerl, H.W., Bebout, B.M. and Prufert, L.E. (1989) Natu- rally occurring patterns of oxygenic photosynthesis and $\mathrm{N}_{2}$ fixation in a marine microbial mat: physiological and ecological ramifications. In: Microbial Mats. Physiological Ecology of Benthic Microbial Communities (Cohen, Y. and Rosenberg, E., Eds.), p. 326-341. American Society for Microbiology, Washington.

[232] Paerl, H.W. and Prufert, L.E. (1987) Oxygen-poor microzones as potential sites of microbial $\mathrm{N}_{2}$ fixation in nitrogen-depleted aerobic marine waters. Appl. Environ. Microbiol., 53, 1078-1087.

[233] Jørgensen, B.B. and Des Marais, D.J. (1988) Optical properties of benthic photosynthetic communities: fiber-optic studies of cyanobacterial mats. Limnol. Oceanog., 33, 99113.

[234] Lassen, C., Ploug, H. and Jørgensen, B.B. (1992) Microalgal photosynthesis and spectral scalar irradiance in coastal marine sediments of Limfjorden, Denmark. Limnol. Oceanog., 37, 760-772.

[235] Stal, L.J. and Krumbein, W.E. (1985) Oxygen protection of nitrogenase in the aerobically nitrogen fixing nonheterocystous cyanobacterium Oscillatoria sp. Arch. Microbiol., 143, 72-76.

[236] Padan, E. and Cohen, Y. (1982) Anoxygenic photosynthesis. In: The Biology of Cyanobacteria (Carr, N.G. and Whitton, B.A., Eds.), p. 215-235. Blackwell, Oxford.

[237] De Wit, R., van Boekel, W.H.M. and van Gemerden, H. (1988) Growth of the cyanobacterium Microcoleus chthonoplastes on sulfide. FEMS Microbiol. Ecol., 53, 203-209.

[238] Stal, L.J. (1991) The sulfur metabolism of mat-building cyanobacteria in anoxic marine sediments. Kieler Meeresforsch., Sonderheft 8, 152-157.

[239] De Wit, R. and Van Gemerden, H. (1988) Interactions between phototrophic bacteria in sediment ecosystems. Hydrobiol. Bull., 22, 135-145.

[240] Richardson, L.L. and Castenholz, R.W. (1987) Diel vertical movements of the cyanobacterium Oscillatoria terebriformis in a sulfide-rich hot spring microbial mat. Appl. Environ. Microbiol., 53, 2142-2150.

[241] Hawkesford, M.J., Reed, R.H., Rowell, P. and Stewart, W.D.P. (1981) Nitrogenase activity and membrane electrogenesis in the cyanobacterium Anabaena variabilis Kutz. Eur. J. Biochem., 115, 519-523.

[242] Hawkesford, M.J., Reed, R.R., Rowell, P. and Stewart, W.D.P. (1982) Nitrogenase activity and membrane electrogenesis in the cyanobacterium Plectonema boryanum. Eur. J. Biochem., 127, 63-66.

[243] Houchins, J.P. (1985) Electron transfer chains of cyanobacterial heterocysts. In: Nitrogen Fixation and $\mathrm{CO}_{2}$ metabolism (Ludden, P.W. and Burris, J.E., Eds.), p. 261-268. Elsevier, New York.

[244] Schrautemeier, B. (1988) How is heterocyst metabolism adapted to nitrogen fixation? In: Nitrogen Fixation: Hundred Years After (Bothe, H., de Bruijn, F.J. and Newton, W.E., Eds.), p. 216. Fischer, Stuttgart.

[245] Schrautemeier, B., Cassing, A. and Böhme, H. (1994) Characterization of the genome region encoding an FdxH-type ferredoxin and a new $2[4 \mathrm{Fe}-4 \mathrm{~S}]$ ferredoxin from the non- 
heterocystous, nitrogen-fixing cyanobacterium Plectonema boryanum PCC 73110. J. Bacteriol., 176, 1037-1046.

[246] Wang, C.-Y. and Wang, F.-Z. (1988) The relationships between nitrogen fixation and several kinds of energy metabolism by a Gloeocapsa sp. Acta Bot. Sinica, 30, 269-277.

[247] Kana, T.M. (1992) Oxygen cycling in cyanobacteria with specific reference to oxygen protection in Trichodesmium spp. In: Marine Pelagic Cyanobacteria: Trichodesmium and other Diazotrophs (Carpenter, E.J., Capone, D.G. and Rueter, J.G., Eds.), p. 29-41. Kluwer, Dordrecht.

[248] Kana, T.M. (1993) Rapid oxygen cycling in Trichodesmium thiebautii. Limnol. Oceanog., 38, 18-24.

[249] Roenneberg, T. and Carpenter, E.J. (1993) Daily rhythm of $\mathrm{O}_{2}$-evolution in the cyanobacterium Trichodesmium thiebautii under natural and constant conditions. Mar. Biol., 117, 693697.

[250] Luo, Y.H. and Mitsui, A. (1994) Hydrogen-production from organic substrates in an aerobic nitrogen-fixing marine unicellular cyanobacterium Synechococcus sp strain Miami BG 043511. Biotechnol. Bioeng., 44, 1255-1260.

[251] Summers, M.L., Wallis, J.G., Campbell, E.L. and Meeks, J.C. (1995) Genetic-evidence of a major role for glucose-6phosphate dehydrogenase in nitrogen fixation and dark growth of the cyanobacterium Nostoc sp strain ATCC 29133. J. Bacteriol., 177, 6184-6194.

[252] Gallon, J.R., Kurz, W.G.W. and LaRue, T.A. (1973) Isocitrate supported nitrogenase activity in Gloeocapsa sp. LB795. Can. J. Microbiol., 19, 461-465.

[253] Ul-Haque, M.I., Gallon, J.R. and Chaplin, A.E. (1977) The intermediary metabolism of the unicellular blue-green alga Gloeocapsa sp. LB795. Biochem. Soc. Trans., 5, 1484-1486.

[254] Grobbelaar, N., Lin, H.-Y. and Huang, T.-C. (1987) Induction of a nitrogenase activity rhythm in Synechococcus and the protection of its nitrogenase against photosynthetic $\mathrm{O}_{2}$. Current Microbiol., 15, 29-33.

[255] Walsby, A.E. (1985) The permeability of heterocysts to the gases nitrogen and oxygen. Proc. R. Soc. Lond. B, 226, 345366.

[256] Potts, M., Angeloni, S.V., Ebel, R.E. and Bassam, D. (1992) Myoglobin in a cyanobacterium. Science, 256, 1690-1692.

[257] Stal, L.J. and Krumbein, W.E. (1987) Temporal separation of nitrogen fixation and photosynthesis in the filamentous, non-heterocystous cyanobacterium Oscillatoria sp. Arch. Microbiol., 149, 76-80.

[258] Vaughn, S. and Burgess, B. (1988) Nitrogenase reactivity toward nitrate and nitrite. In: Nitrogen Fixation: Hundred Years After (Bothe, H., de Bruijn, F.J. and Newton, W.E., Eds.), p. 138. Fischer, Stuttgart.

[259] Seefeldt, L.C., Rasche, M.E. and Ensign, S.A. (1995) Carbonyl sulfide and carbon dioxide as new substrates, and carbon disulfide as a new inhibitor, of nitrogenase. Biochemistry, 34, 5382-5389.

[260] Thorneley, R.N.F. and Ashby, G.A. (1989) Oxidation of nitrogenase iron protein by dioxygen without inactivation could contribute to high respiration rates of Azotobacter species and facilitate nitrogen fixation in aerobic environments. Biochem. J., 261, 181-187.
[261] Linkerhägner, K. and Oelze, J. (1995) Cellular ATP levels and nitrogenase switchoff upon oxygen stress in chemostat cultures of Azotobacter vinelandii. J. Bacteriol., 177, 52895293.

[262] Elhai, J. and Wolk, C.P. (1991) Hierarchical control by oxygen in heterocysts of Anabaena. In: 6th International Symposium on Photosynthetic Prokaryotes, Amherst, Massachusetts, USA. University of Massachusetts. p.114B.

[263] Smith, R.L., Van Baalen, C. and Tabita, F.R. (1987) Alteration of the Fe protein of nitrogenase by oxygen in the cyanobacterium Anabaena sp. strain CA. J. Bacteriol., 169, 2537-2542.

[264] Gallon, J.R., Farrow, P. and Restall, C.J. (1993) Measurement of intracellular oxygen in $\mathrm{N}_{2}$-fixing Gloeothece. In: New Horizons in Nitrogen Fixation (Palacios, R., Mora, J. and Newton, W.E., Eds.), p. 463. Kluwer, Dordrecht.

[265] Page, T.S. and Gallon, J.R. (1992) DNA topoisomerases in Gloeothece (Nägeli) sp. ATCC 27152: a role in $\mathrm{N}_{2}$ fixation? New Phytol., 121, 33-42.

[266] Moshiri, F., Kim, J.W., Fu, C.L. and Maier, R.J. (1994) The FeSII protein of Azotobacter vinelandii is not essential for aerobic nitrogen fixation, but confers significant protection to oxygen-mediated inactivation of nitrogenase in vitro and in vivo. Molec. Microbiol., 14, 101-114.

[267] Mullineaux, P.M., Gallon, J.R. and Chaplin, A.E. (1981) Acetylene reduction (nitrogen fixation) by cyanobacteria grown under alternating light-dark cycles. FEMS Microbiol. Lett., 10, 245-247.

[268] Mitsui, A., Cao, S., Takahashi, A. and Arai, T. (1987) Growth synchrony and cellular parameters of the unicellular nitrogen-fixing marine cyanobacterium, Synechococcus sp. strain Miami BG 043511 under continuous illumination. Physiol. Plantarum, 69, 1-8.

[269] Kumazawa, S. and Mitsui, A. (1992) Photosynthetic activities of a synchronously grown aerobic $\mathrm{N}_{2}$-fixing unicellular cyanobacterium, Synechococcus sp. Miami BG 043511. J. Gen. Microbiol., 138, 467-472.

[270] Campbell, C., Takeyama, H. and Mitsui, A. (1994) Cyclic synthesis of messenger RNA from nitrogenase nifH gene in synchronous cultures of marine unicellular cyanobacterium, Synechococcus sp. strain Miami BG043511. J. Mar. Biotechnol., 2, 39-43.

[271] Grobbelaar, N., Huang, T.C., Lin, H.Y. and Chow, T.J. (1986) Dinitrogen-fixing endogenous rhythm in Synechococcus RF-1. FEMS Microbiol. Lett., 37, 173-177.

[272] Huang, T.-C., Tu, J., Chow, T.-J. and Chen, T.-H. (1990) Circadian rhythm of the prokaryote Synechococcus sp. RF-1. Plant Physiol., 92, 531-533.

[273] Huang, T.-C. and Chou, W.-M. (1991) Setting of the circadian $\mathrm{N}_{2}$-fixing rhythm of the prokaryotic Synechococcus sp. RF-1 while its nif gene is repressed. Plant Physiol., 96, 324 326.

[274] Grobbelaar, N. and Huang, T.-C. (1992) Effect of oxygen and temperature on the induction of a circadian rhythm in Synechococcus RF-1. J. Plant Physiol., 140, 391-394.

[275] Huang, T.-C., Wang, S.-T. and Grobbelaar, N. (1993) Cir- 
cadian rhythm mutants of the prokaryotic Synechococcus RF-1. Current Microbiol., 27, 249-253.

[276] Huang, T.-C. and Pen, S.-Y. (1994) Induction of a circadianrhythm in Synechococcus RF-1 while the cells are in a suspended state. Planta, 194, 436-438.

[277] Edmunds, L.N., Jr. (1988) Cellular and Molecular Basis of Biological Clocks. Models and Mechanisms of Circadian Timekeeping. Springer, New York.

[278] Sweeny, B.M. and Borgese, M.B. (1989) A circadian rhythm in cell division in a prokaryote: the cyanobacterium Synechococcus WH7803. J. Phycol., 25, 183-186.

[279] Kondo, T., Strayer, C.A., Kulkarni, R.D., Taylor, W., Ishiura, M., Golden, S.S. and Johnson, C.H. (1993) Circadian-rhythms in prokaryotes: luciferase as a reporter of circadian gene-expression in cyanobacteria. Proc. Natl. Acad. Sci. USA, 90, 5672-5676.

[280] Liu, Y., Golden, S.S., Kondo, T., Ishiura, M. and HirschieJohnson, C. (1995) Bacterial luciferase as a reporter of cir- cadian gene expression in cyanobacteria. J. Bacteriol., 177, 2080-2086.

[281] Aoki, S., Kondo, T. and Ishiura, M. (1995) Circadian expression of the dnaK gene in the cyanobacterium Synechocystis sp. strain PCC 6803. J. Bacteriol., 177, 5606-5611.

[282] Chen, T.-H., Chen, T.-L., Hung, L.-M. and Huang, T.-C. (1991) Circadian rhythm in amino acid uptake by Synechococcus RF-1. Plant Physiol., 97, 55-59.

[283] Rojek, R., Harms, C., Hebeler, M. and Grimme, L.H. (1994) Cyclic variations of photosynthetic activity under nitrogenfixing conditions in Synechococcus RF-1. Arch. Microbiol., 162, 80-84.

[284] Huang, T.-C., Chen, H.-M., Pen, S.-Y. and Chen, T.-H. (1994) Biological clock in the prokaryote Synechococcus RF-1. Planta, 193, 131-136.

[285] Myint, K.S. (1991) The interaction of photosynthesis and nitrogen fixation in the unicellular cyanobacterium Gloeothece PCC 6909. PhD thesis, University of Oldenburg. 